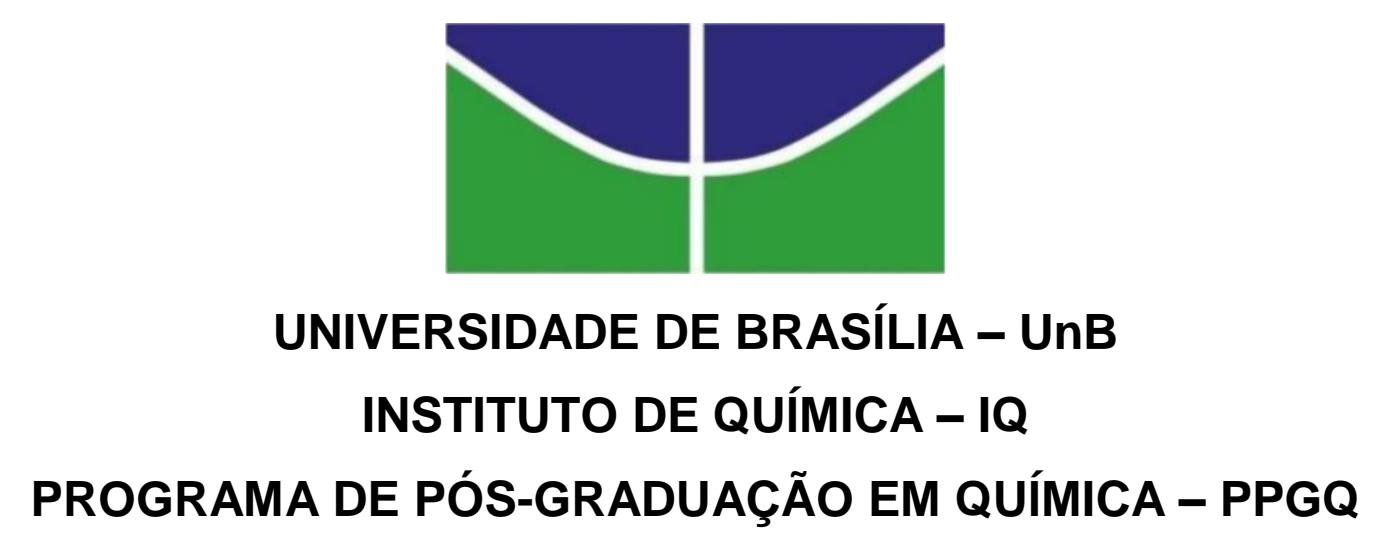

\title{
Compósitos Poliméricos ObTidos PeLA COMBINAÇÃo de ESTIRENO E LIGNINA
}

\author{
DISSERTAÇÃO DE MESTRADO
}

PRISCILLA ARAUJO VICTOR

Orientador: Prof. Fabricio Machado Silva, DSc.

Coorientadora: Dr. Sílvia Belém Gonçalves, DSc. 


\author{
UNIVERSIDADE DE BRASÍLIA - UnB \\ INSTITUTO DE QUÍMICA - IQ \\ PROGRAMA DE PÓS-GRADUAÇÃO EM QUÍMICA - PPGQ
}

\title{
Compósitos Poliméricos OBTIDOS PELA CombinaçÃo dE EstiRENO E LIGNINA
}

\author{
Dissertação apresentada ao \\ Programa de Pós-Graduação em \\ Química do Instituto de Química da \\ Universidade de Brasília. Área de \\ concentração Química Analítica, \\ como requisito parcial para a \\ obtenção do título de Mestre em \\ Química.
}

PRISCILLA ARAUJO VICTOR

Orientador: Prof. Fabricio Machado Silva, DSc.

Coorientadora: Dr. Sílvia Belém Gonçalves, DSc.

Brasília, Dezembro de 2014 


\section{DEDICATÓRIA}

A Deus, pela vida.

À minha família, com amor.

Aos meus orientadores, eterna gratidão.

Piedoso e Justo é o Senhor;

o nosso Deus é cheio de compaixão.

O Senhor protege os simples;

quando eu estava abatido, Ele me livrou.

O que darei eu ao Senhor, por todos o benefícios que me te feito?

Salmos 116: 5, 6 e 12 


\section{AGRADECIMENTOS}

A Deus, em primeiro lugar, pela sabedoria que Ele me concedeu e pela vida.

Aos meus pais, Marcos e Sônia, que sempre estiveram ao meu lado me ajudando a não desistir nunca dos meus sonhos, mesmo sendo difíceis de realizar;

À minha irmã Raquel e meu cunhado favorito Lincoln pelos conselhos e o encorajamento;

À professora Vanda Maria de Oliveira, pela maravilhosa indicação de trabalhar com o Professor Fabricio Machado e com polímeros;

À professora Sarah Silva Brum, que, em uma palestra, me apresentou o material que agora faz parte deste trabalho, a lignina. Obrigada Sarah!

Ao meu orientador professor Fabricio Machado Silva, uma pessoa inigualável que tive a privilégio de trabalhar. Nunca me esquecerei de você. Serei eternamente grata por todo ensinamento, conselhos e nunca me deixar desistir. Esse trabalho não teria saído do papel sem você. Obrigada pela paciência!

À minha coorientadora Sílvia Belém Gonçalves, pela oportunidade de trabalhar na Embrapa Agroenergia, pelas correções e conselhos. Obrigada!

À Unidade da Embrapa Agroenergia e as analistas do Laboratório de Processos Bioquímicos (LPB), famosas "meninas do aquário" Carolina, Thályta, Thaís e Patrícia, pelas risadas e auxilio durante a minha pesquisa. Obrigada pelo acolhimento.

Ao pesquisador Leonardo Fonseca Valadares, pelo auxílio com microscópios e o reômetro, equipamentos importantes para a conclusão desde trabalho.

À Anna Leticia Montenegro Turtelli Pighinelli pelo apoio e auxílio como reômetro.

À todos os colegas do Laboratório de Processos Químicos do Instituto de Química, e principalmente a Gabriela, Alan e Juliete. Obrigada pela ajuda.

Aos colegas do LMC, LAQUIMET, Laboratório Multiusuários e a todos que direta ou indiretamente me ajudaram a realizar esse trabalho. 


\section{RESUMO}

A lignina é um polímero natural proveniente de materiais lignocelulósicos de grande disponibilidade, originado em grande escala, e com enorme potencial para aplicação na produção de novos materiais poliméricos compósitos. Devido sua estrutura macromolecular complexa e a sua reduzida compatibilidade com o estireno, a lignina extraída da madeira de eucalipto pelo método Kraft modificado foi esterificada com anidrido metacrílico (exibindo um rendimento de aproximadamente $64 \%$ ) para assegurar a homogeneidade da fase orgânica no meio reacional de polimerização. $O$ processo de polimerização sequencial do tipo massa-suspensão foi escolhido com o objetivo de garantir a adequada dispersão da lignina no meio reacional. A caracterização da lignina natural e a lignina esterificada por infravermelho (IV) mostrou a diminuição da banda característica das hidroxilas da lignina natural (3200 $\mathrm{cm}^{-1}-3400 \mathrm{~cm}^{-1}$ ) e um aumento da banda característica de ésteres $\left(1720 \mathrm{~cm}^{-1}-1740 \mathrm{~cm}^{-1}\right)$. Em ensaios de ressonância magnética nuclear ( ${ }^{1} \mathrm{H}$ RMN) foram observados picos intensos na faixa entre 1,7 ppm - 2,05 ppm $\left(-\mathrm{CH}_{3}\right)$ e $5,4 \mathrm{ppm}-6,2 \mathrm{ppm}\left(=\mathrm{CH}_{2}\right)$ característicos do anidrido metacrílico, corroborando os resultados de IV. De acordo com as análises termogravimétricas (TGA), a lignina esterificada apresentou uma diminuição em sua estabilidade térmica quando comparada a lignina natural, exibindo duas perdas de massa significativas, entre $200^{\circ} \mathrm{C}$ e $300^{\circ} \mathrm{C}$ e entre $550^{\circ} \mathrm{C}$ e $800^{\circ} \mathrm{C}$. Comparativamente, a lignina esterificada teve sua temperatura de transição vítrea $(\mathrm{Tg})$ aumentada para $98^{\circ} \mathrm{C}$, em relação a lignina natural, cuja $\mathrm{Tg}$ foi determinada igual a $91^{\circ} \mathrm{C}$. Os compósitos poliméricos obtidos pela combinação de estireno com lignina natural e/ou esterificada, na proporção de $5 \%, 10 \%$ e $20 \%$ de lignina, foram produzidos com sucesso, apresentando partículas com morfologia regular. A incorporação de lignina (natural ou esterificada) resultou em um aumento significativo da viscosidade dos polímeros em comparação aos resultados obtidos para o poliestireno puro. Adicionalmente, os materiais poliméricos oriundos dos ensaios de viscosidades foram conduzidos a uma nova caracterização térmica em ensaios de TGA e DSC, mostrando que a boa estabilidade térmica é mantida com perdas de massa entre $350^{\circ} \mathrm{C}$ e $480^{\circ} \mathrm{C}$. Em particular para os compósitos contendo lignina esterificada, a $\mathrm{Tg}$ aumentou em relação ao poliestireno puro, como o resultado da copolimerização entre o estireno e a lignina esterificada. 


\begin{abstract}
Lignin is a lignocellulosic materials-derived natural polymer with high availability, produced in large-scale, presenting a huge potential for production of new polymeric composites. Due to its complex macromolecular structure, and its low compatibility with styrene, eucalyptus wood-extracted lignin through modified Kraft method was esterified with methacrylic anhydride - exhibiting a yield of $64 \%$ - in order to ensure homogeneity in the organic phase into the reaction medium. The mass-suspension sequential polymerization process was employed in order to ensure adequate dispersion of lignin in the reaction medium. The evaluation of both the natural and esterified lignin through infrared (IR) spectroscopy showed a decrease of the hydroxyl band, characteristic of natural lignin (3200-3400 $\left.\mathrm{cm}^{-1}\right)$ and an increase of the characteristic ester band (1720 to $\left.1740 \mathrm{~cm}^{-1}\right)$. According to nuclear magnetic resonance $\left({ }^{1} \mathrm{H}\right.$ NMR), intense peaks were observed in the range from 1.7 to $2.05 \mathrm{ppm}\left(-\mathrm{CH}_{3}\right)$ and $5.4 \mathrm{ppm}$ to $6.2 \mathrm{ppm}\left(=\mathrm{CH}_{2}\right)$, related to methacrylic anhydride. According to the thermogravimetric analysis (TGA), esterified lignin showed a decrease in its thermal stability when compared to natural lignin, exhibiting two main weight losses between $200^{\circ} \mathrm{C}$ and $300^{\circ} \mathrm{C}$ and in the interval from $550{ }^{\circ} \mathrm{C}$ to $800{ }^{\circ} \mathrm{C}$. Comparatively, the esterified lignin also displayed an increase in its glass transition temperature $(\mathrm{Tg})$ for para $98^{\circ} \mathrm{C}$, related to natural lignin, whose $\mathrm{Tg}$ was determined to be equal to $91^{\circ} \mathrm{C}$. The polymer composites obtained by the combination of styrene and natural or esterified lignin, in a proportion of $5 \%, 10 \%$ and $20 \%$ of lignin, were successfully synthesized, presenting regular morphology. The incorporation of lignin (natural and modified) into the thermoplastic matrix of polystyrene (PS) led to a significant increase in the viscosity of polymer composites, in comparison to the one observed for the pure PS. Additionally, polymeric materials from viscosity essays were analyzed once more by thermal analysis (TGA and DSC), showing that the good thermal stability is kept, displaying weight losses lying in the interval from $350^{\circ} \mathrm{C}$ e $480^{\circ} \mathrm{C}$. Particularly for the polymer composites containing modified lignin, the $\mathrm{Tg}$ was increased in comparison to pure PS, as a result of copolymerization between styrene and esterified lignin.
\end{abstract}




\section{SUMÁRIO}

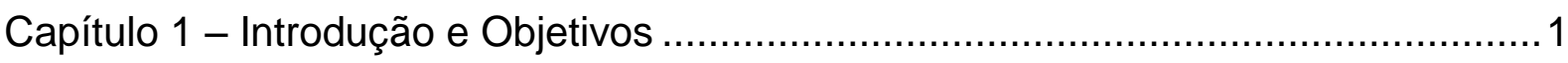

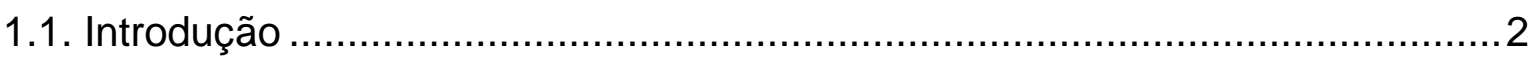

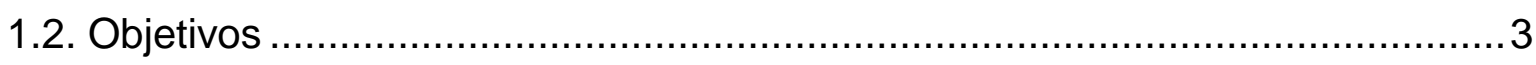

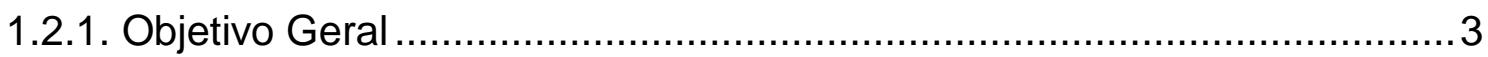

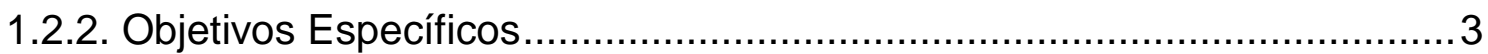

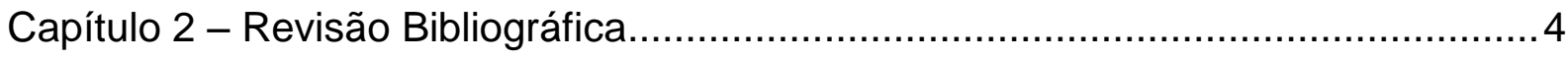

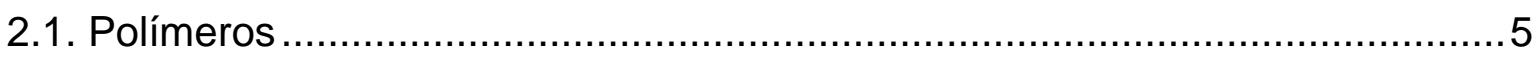

2.1.1. Materiais Compósitos.................................................................

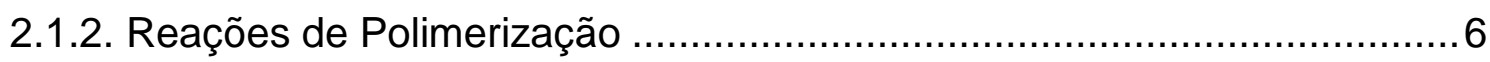

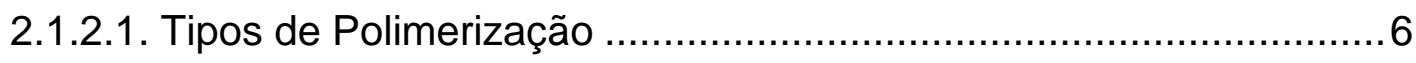

2.1.2.1.1.Polimerização em Massa ..................................................

2.1.2.1.2.Polimerização em Suspensão ............................................

2.1.2.1.3. Polimerização em Massa-Suspensão ................................... 8

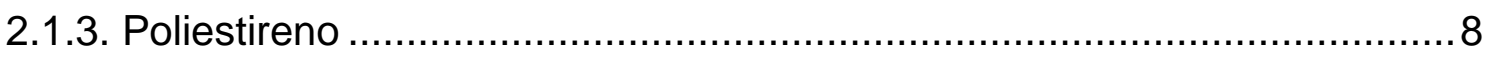

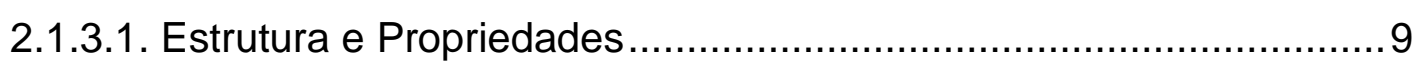

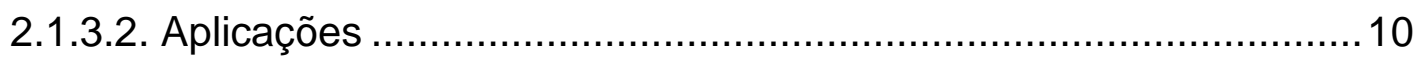

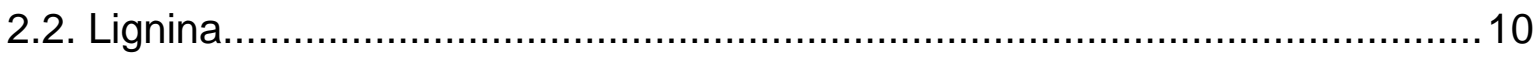

2.2.1. Composição e Estrutura................................................................... 12

2.2.2. Métodos de Separação dos Componentes Lignocelulósicos..................13

2.2.2.1. Lignina Kraft ....................................................................... 14

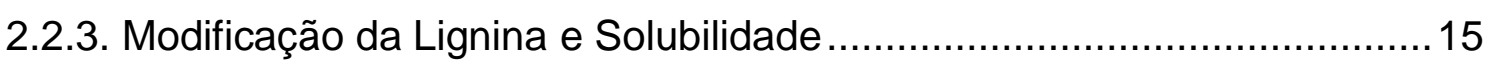

2.2.4. Materiais Produzidos com Lignina .................................................... 16

Capítulo 3 - Material e Métodos....................................................................... 18

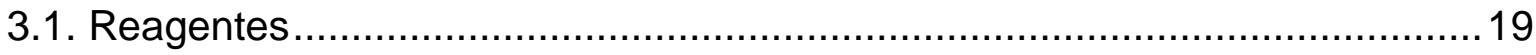

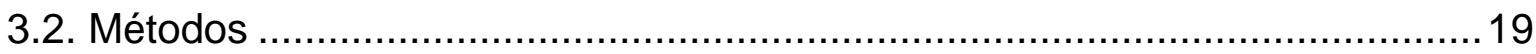

3.2.1. Determinação do Teor de Lignina na Madeira ...................................... 19

3.2.2. Extração da Lignina pelo Método Kraft Modificado ................................20

3.2.3. Extração da Lignina pelo Método Kraft com Pré-tratamento com Acetona 20

3.2.4. Processo de Polimerização em Massa-Suspensão .................................20 


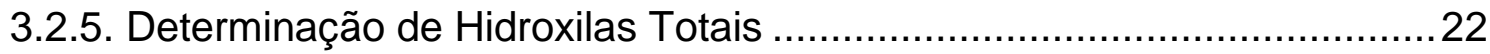

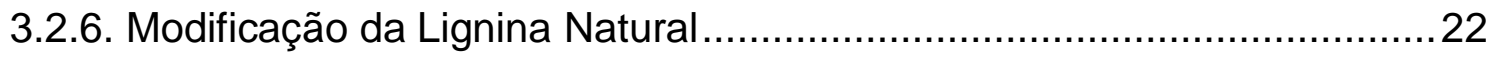

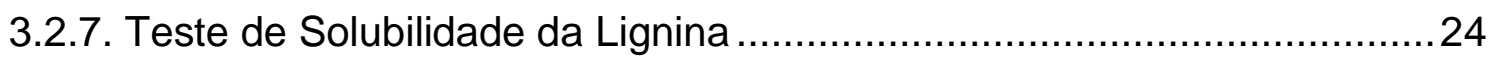

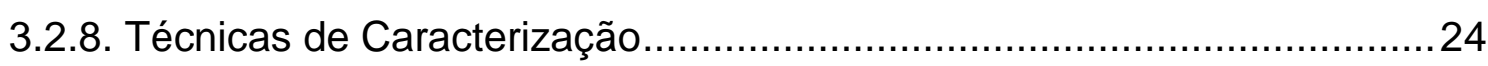

3.2.8.1. Espectroscopia na Região do Infravermelho (IV) .........................24

3.2.8.2. Ressonância Magnética Nuclear (RMN) ......................................25

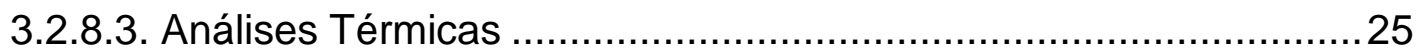

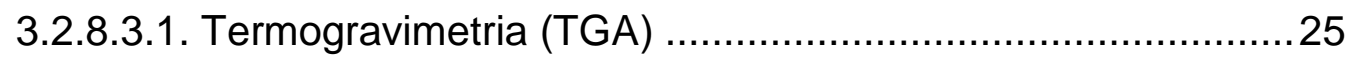

3.2.8.3.2. Calorimetria Diferencial de Varredura (DSC) ......................25

3.2.8.4. Microscopia Eletrônica de Varredura (MEV) ................................25

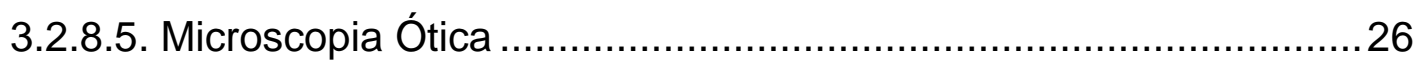

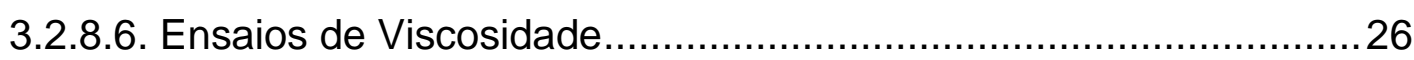

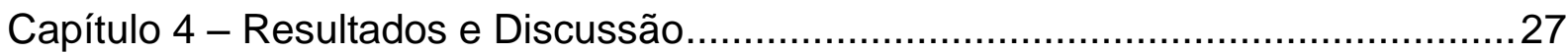

4.1. Determinação do Teor de Lignina na Madeira ............................................28

4.2. Extração e Caracterização da Lignina Natural ................................................ 28

4.3. Esterificação da Lignina e sua Caracterização ........................................... 33

4.4. Polimerização em Massa-Suspensão com Estireno e Lignina Natural ...........38

4.5. Polimerização em Massa-Suspensão com Estireno e Lignina Esterificada ... 48

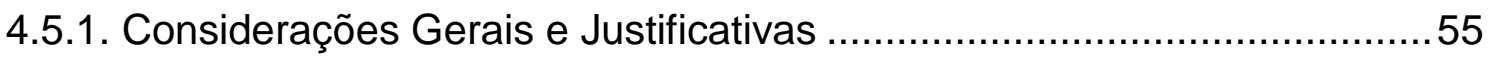

4.6. Ensaios de Viscosidade e Avaliação Térmica dos Polímeros ........................57

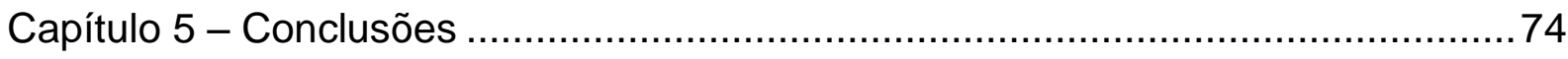

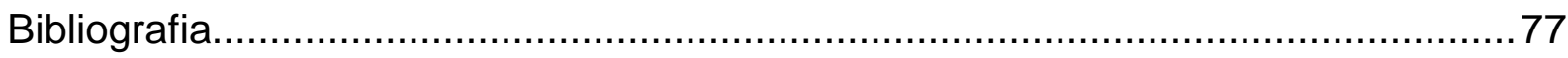




\section{LISTA DE TABELAS}

Tabela 1: Composição da mistura reacional da polimerização em massa-suspensão com estireno e lignina natural.

Tabela 2: Composição da mistura reacional da polimerização em massa-suspensão com estireno e lignina esterificada.

Tabela 3: Dados obtidos na triplicata do experimento para determinação do teor de lignina na madeira

Tabela 4: Bandas de absorção características da lignina

Tabela 5: Atribuições dos principais sinais de hidrogênio do espectro de $\mathrm{RMN}^{1} \mathrm{H}$ da lignina natural 32

Tabela 6: Dados obtidos na triplicata para determinação de hidroxilas na lignina natural

Tabela 7: Dados obtidos na triplicata para determinação de hidroxilas na lignina esterificada

Tabela 8: Condições experimentais dos processos de polimerização em massasuspensão usando lignina natural.

Tabela 9: Condições experimentais dos processos de polimerização em massasuspensão usando lignina esterificada.

Tabela 10: Condições experimentais do teste de pH da lignina natural. 56

Tabela 11: Condições experimentais do teste de $\mathrm{pH}$ da lignina esterificada. 56

Tabela 12: Dados experimentais dos processos de polimerização em massasuspensão do estireno

Tabela 13: Caracterização térmica do poliestireno e dos polímeros formados com poliestireno/lignina $5 \%$ e poliestireno/lignina esterificada $5 \%$.

Tabela 14: Caracterização térmica do poliestireno e dos polímeros formados com poliestireno/lignina $5 \%$ e poliestireno/lignina esterificada $5 \%$. 
Tabela 15: Caracterização térmica do poliestireno e dos polímeros formados com poliestireno/lignina $10 \%$ e poliestireno/lignina esterificada $10 \% \ldots \ldots \ldots \ldots \ldots \ldots \ldots \ldots \ldots \ldots . . .72$

Tabela 16: Caracterização térmica do poliestireno e dos polímeros formados com poliestireno/lignina $20 \%$ e poliestireno/lignina esterificada $20 \% \ldots \ldots \ldots \ldots \ldots \ldots \ldots \ldots \ldots . . . . .73$ 


\section{LISTA DE FIGURAS}

Figura 1: Estrutura representativa do poliestireno

Figura 2: Celulose rodeada por hemicelulose e lignina. Adaptada de Doherty et al.11

Figura 3: Estruturas primárias da lignina. 12

Figura 4: Estrutura da lignina, proposta por Nimtz. 13

Figura 5: Conversão de grupos hidroxilas em ésteres. (a) acético, (b) propanóico, (c) butílico, (d) maléico, e (e) metacrílico.

Figura 6: Sistema reacional utilizado para as reações de polimerização massasuspensão de estireno/lignina e estireno/lignina esterificada. Onde; (a) reator de borossilicato de $250 \mathrm{~mL}$, (b) condensador, (c) agitador mecânico com impelidor.....21

Figura 7: Sistema reacional utilizado para as reações de esterificação da lignina. Onde: (a) balão de $250 \mathrm{~mL}$, (b) banho de óleo, (c) termopar, (d) entrada de gás nitrogênio, (e) condensador de refluxo e (f) placa de aquecimento e agitação magnética.

Figura 8: Esquema de reação de esterificação usando o 1-metilimidazol. 23

Figura 9: Sistema para teste de solubilidade da lignina e lignina esterificada. Onde: (a) tubos de ensaio, (b) banho de óleo, (c) termopar e (d) placa de aquecimento e agitação magnética. 24

Figura 10: Sistema para ensaios de viscosidade. Onde: $[A]$ (a) viscosímetro, (b) thermosel, (c) controle de temperatura, (d) suporte de alinhamento e (e) porta

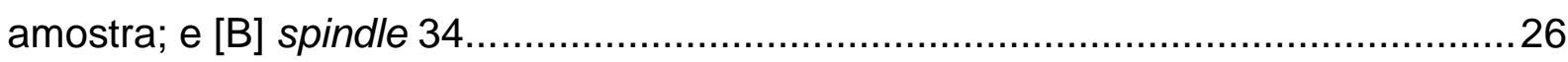

Figura 11: Espectro no IV da lignina natural de madeira de eucalipto.. ...................30

Figura 12: Estabilidade térmica da lignina natural de madeira de eucalipto..............30

Figura 13: Termograma da lignina natural de madeira de eucalipto. ......................31

Figura 14: Espectro de $\mathrm{RMN}{ }^{1} \mathrm{H}$ da lignina natural de madeira de eucalipto.............32 
Figura 15: Imagens de microscopia ótica da lignina natural com escalas de $50 \mu \mathrm{m}$

Figura 16: Micrografias de MEV, onde: (a) madeira moída, (b) amostra de lignina natural com tamanhos entre 100-150 $\mu \mathrm{m}$ e com aproximação de 65 vezes, (c) lignina natural com tamanhos entre 25-100 $\mu \mathrm{m}$ e aproximação de 350 vezes e (d) lignina natural com aproximação de 1600 vezes da área em destaque da micrografia (c)...33

Figura 17: Espectros no IV da lignina natural e esterificada 35

Figura 18: Estabilidade térmica da lignina natural e esterificada. .36

Figura 19: Termograma da lignina natural e esterificada 36

Figura 20: Espectro de $\mathrm{RMN}{ }^{1} \mathrm{H}$ da lignina natural e esterificada. 37

Figura 21: Micrografias de MEV da lignina esterificada.

Figura 22: Curva de conversão da polimerização em massa de estireno 39

Figura 23: Imagens de microscopia ótica da amostra 1 dos polímeros obtidos a partir de $5 \%$ de lignina natural e conversão de $93,1 \%$, em destaque as regiões com lignina livre..

Figura 24: Distribuição do tamanho de partícula da amostra 1 dos polímeros obtidos a partir de $5 \%$ de lignina natural e conversão de $93,1 \%$. 40

Figura 25: Micrografia de MEV da amostra 2 dos polímeros obtidos a partir de $5 \%$ de lignina natural e conversão de $96,1 \%$..

Figura 26: Imagens de microscopia ótica da amostra 2 dos polímeros obtidos a partir de $5 \%$ de lignina natural e conversão de $96,1 \%$, em destaque as regiões com lignina livre.

Figura 27: Distribuição de partícula da amostra 2 dos polímeros obtidos a partir de 5 $\%$ de lignina natural e conversão de $96,1 \%$.

Figura 28: Imagens de microscopia ótica da amostra 3 dos polímeros obtidos a partir de $5 \%$ de lignina natural e conversão de 97,3\%. 
Figura 29: Distribuição de partícula ótica da amostra 3 dos polímeros obtidos a partir de $5 \%$ de lignina natural e conversão de $97,3 \%$.

Figura 30: Micrografia de MEV da amostra 3 dos polímeros obtidos a partir de $5 \%$ de lignina natural.

Figura 31: Imagens de microscopia ótica dos polímeros obtidos a partir de $5 \%$ de lignina natural.

Figura 32: Imagens de microscopia ótica da Amostra 5 dos polímeros obtidos a partir de $10 \%$ de lignina natural e conversão de $78,3 \%$.

Figura 33: Imagens de microscopia ótica dos polímeros obtidos a partir de $10 \%$ de lignina natural e conversão de $84,3 \%$.

Figura 34: Micrografia de MEV da Amostra 7 dos polímeros obtidos a partir de $10 \%$ de lignina natural.

Figura 35: Imagens de microscopia ótica da amostra 7 dos polímeros obtidos a partir de $10 \%$ de lignina natural e conversão de $97,8 \%$.

Figura 36: Imagem dos polímeros obtidos, onde: (a) poliestireno, (b) $5 \%$ de lignina natural, (c) $10 \%$ de lignina natural e (d) $20 \%$ de lignina natural.

Figura 37: Micrografia de MEV da Amostra 1 dos polímeros obtidos a partir de $5 \%$ de lignina esterificada, na polimerização em suspensão.

Figura 38: Micrografia de MEV da amostra 4 dos polímeros obtidos a partir de $5 \%$ de lignina esterificada.

Figura 39: Imagens de microscopia ótica da amostra 4 dos polímeros obtidos a partir de $5 \%$ de lignina esterificada..

Figura 40: Micrografia de MEV da amostra 5 dos polímeros obtidos a partir de $10 \%$ de lignina esterificada.

Figura 41: Imagens de microscopia ótica da amostra 5 dos polímeros obtidos a partir de $10 \%$ de lignina esterificada. 
Figura 42: Imagens dos polímeros obtidos a partir de $20 \%$ de lignina esterificada e $50 \mathrm{~g} / \mathrm{L}$ de solução de agente de suspensão.

Figura 43: Imagens dos polímeros obtidos com estireno e lignina esterificada, onde: (a) $5 \%$ de lignina esterificada (Amostra 4), (b) $10 \%$ de lignina esterificada (Amostra5) e (c) $20 \%$ de lignina esterificada (Amostra 7).

Figura 44: Imagem dos polímeros formados, onde: (a) poliestireno, (b) $5 \%$ de lignina esterificada, (c) $10 \%$ de lignina esterificada e (d) $20 \%$ de lignina esterificada.

Figura 45: Perfis de viscosidade das amostras preliminares, onde: (a) poliestireno, (b) poliestireno/lignina $5 \%$ e (c) poliestireno/lignina esterificada $5 \%$ 59

Figura 46: Estabilidade térmica das análises preliminares dos polímeros, onde: (a) poliestireno, (b) poliestireno/lignina $5 \%$ e (c) poliestireno/lignina esterificada $5 \%$...60 Figura 47: Curvas de DSC das análises preliminares dos polímeros, onde: (a) poliestireno, (b) poliestireno/lignina $5 \%$ e (c) poliestireno/lignina esterificada $5 \%$...61

Figura 48: Perfis de viscosidade, onde: (a) poliestireno, (b) poliestireno/lignina $5 \%$ e (c) poliestireno/lignina esterificada $5 \%$.

Figura 49: Perfis de viscosidade, onde: (a) poliestireno, (b) poliestireno/lignina $10 \%$ e (c) poliestireno/lignina esterificada $10 \%$.

Figura 50: Perfis de viscosidade, onde: (a) poliestireno, (b) poliestireno/lignina $20 \%$ e (c) poliestireno/lignina esterificada $20 \%$.

Figura 51: Estabilidade térmica dos polímeros, onde: (a) poliestireno, (b) poliestireno/lignina $5 \%$ e (c) poliestireno/lignina esterificada $5 \%$.

Figura 52: Estabilidade térmica dos polímeros, onde: (a) poliestireno, (b) poliestireno/lignina $10 \%$ e (c) poliestireno/lignina esterificada $10 \%$.......................67

Figura 53: Estabilidade térmica dos polímeros, onde: (a) poliestireno, (b) poliestireno/lignina $20 \%$ e (c) poliestireno/lignina esterificada $20 \%$.

Figura 54: Curvas de DSC dos polímeros, onde: (a) poliestireno, (b) poliestireno/lignina $5 \%$ e (c) poliestireno/lignina esterificada $5 \%$. 
Figura 55: Curvas de DSC dos polímeros, onde: (a) poliestireno, (b) poliestireno/lignina $10 \%$ e (c) poliestireno/lignina esterificada $10 \%$.......................70 


\section{LISTA DE SÍMBOLOS, NOMENCLATURAS E ABREVIAÇÕES}

$\begin{array}{ll}\text { ATR } & \text { Refletância Total Atenuada } \\ \text { BPO } & \text { Peróxido de Benzoíla } \\ \text { DSC } & \text { Calorimetria Diferencial Exploratória } \\ \text { HIPS } & \text { Poliestireno de alto impacto } \\ \text { IV } & \text { Infravermelho } \\ \text { MA } & \text { Anidrido Maleico } \\ \text { MEV } & \text { Microscopia Eletrônica de Varredura } \\ \text { PIP } & \text { Ponto de identificação de partícula } \\ \text { PS } & \text { Poliestireno } \\ \text { PVA } & \text { Poli(álcool vinílico) } \\ \text { RMN } & \text { Ressonância Magnética Nuclear } \\ \text { SBR } & \text { Copolímero de estireno e butadieno } \\ \text { Tg } & \text { Temperatura de Transição Vítrea } \\ \text { TGA } & \text { Termogravimetria } \\ \text { TMS } & \text { Tetrametilsilano }\end{array}$


CAPÍTULO 1 INTRODUÇÃO E OBJETIVOS 


\subsection{INTRODUÇÃO}

As questões ambientais nunca foram tão discutidas como nos últimos tempos, apresentando como ponto central o desenvolvimento sustentável como uma tentativa de prover as necessidades da população na atualidade sem prejudicar as gerações futuras. Com o crescente consumo, aumentam também a quantidade e a variedade de resíduos gerados e, em especial, os resíduos de biomassa têm sido um problema para o meio ambiente quando o descarte ou armazenamento é feito de maneira incorreta. Para minimizar o descarte inapropriado desses materiais, uma alternativa é transformar o que seria "lixo" em matéria prima na produção de novos materiais poliméricos. ${ }^{1}$

Os polímeros ganharam destaque especial nas últimas décadas por exibir inúmeras propriedades de interesse tecnológico como resistência mecânica e química, leveza, durabilidade, isolamento térmico e elétrico, entre outras. Na busca pela melhoria de propriedades mecânicas e térmicas desses polímeros, é comum a incorporação de cargas inorgânicas ou orgânicas, micro ou nanoparticuladas, ou fases elastoméricas de polímeros orgânicos com a finalidade de produzir compósitos ou nanocompósitos com propriedades melhoradas. ${ }^{2}$

O poliestireno (PS) é uma das commodities poliméricas mais produzidas no mundo, sendo sintetizada principalmente via polimerização radicalar em processos de polimerização em fase heterogênea, como suspensão e emulsão. A despeito da elevada produção mundial e de suas características peculiares, como por exemplo, elevada temperatura de transição vítrea, brilho, dureza, elevado índice de refração e rigidez, a produção de grades poliméricos a base de estireno apresenta como grande desafio a obtenção de poliestirenos menos frágeis (quebradiços), o que corresponde a sua principal desvantagem. ${ }^{1}$

A lignina é considerada um dos materiais mais resistentes na natureza, conferindo firmeza, impermeabilidade e rigidez ao conjunto de fibras de celulose além da resistência ao ataque de fungos. Como parte da estrutura, a lignina age como "cola" preenchendo os espaços entre e em torno da celulose e hemicelulose, por isso tem o papel de suporte na estrutura da biomassa. Devido a estas propriedades, a lignina pode ser empregada para obtenção de materiais com alto valor agregado, como por exemplo, polímeros. ${ }^{3}$ 
Atualmente, materiais poliméricos encontram aplicação em inúmeros segmentos tecnológicos e industriais, cuja obtenção e/ou melhoramento das propriedades macromoleculares dos polímeros tradicionais representa um importante desafio. ${ }^{4}$

\subsection{OBJETIVOS}

\subsubsection{OBJETIVO GERAL}

Este trabalho tem como principal objetivo o desenvolvimento de uma nova classe de materiais poliméricos obtidos através da polimerização de lignina esterificada e estireno, e pela incorporação de lignina in natura em matrizes de poliestireno também in situ via processo de polimerização sequencial do tipo massasuspensão.

\subsubsection{OBJETIVOS ESPECÍFICOS}

Os objetivos específicos deste trabalho foram:

- Extrair a lignina da madeira de Eucalipto pelo Método Kraft Modificado.

- Modificar a estrutura da lignina pelo processo de esterificação com anidrido metacrílico.

- Caracterizar a lignina natural e a lignina esterificada por termogravimetria (TGA), calorimetria diferencial de varredura (DSC), infravermelho (IV), ressonância magnética nuclear ${ }^{1} \mathrm{H}(\mathrm{RMN})$ e microscopia eletrônica de varredura (MEV).

- Produzir o material polimérico in situ via polimerização sequencial do tipo massa-suspensão de $i$ ) lignina in natura e estireno; ii) lignina esterificada e estireno.

- Analisar o material polimérico por termogravimetria (TGA), calorimetria diferencial de varredura (DSC), microscopia ótica e microscopia de eletrônica de varredura (MEV), ensaios de viscosidade e avaliação do comportamento térmico e ressonância magnética nuclear $\mathrm{H}^{1}$ (RMN). 
CAPÍTULO 2

REVISÃO BIBLIOGRÁFICA 


\subsection{POLÍMEROS}

A expressão polímero é oriunda da junção de duas palavras gregas poli (várias) e mero (parte). São formados por unidades químicas denominadas monômeros, que se repetem ao longo de sua cadeia. Os monômeros são caracterizados pelo tamanho, estrutura química e interação intra e intermoleculares. ${ }^{5,6}$

De acordo com sua origem, os polímeros podem ser classificados em dois tipos: naturais como a celulose ou sintético como o poliestireno (PS). A segunda classificação, que estabelece uma distinção entre dois grupos grandes [termoplásticos (plásticos) e termofixos] é também bastante usual. ${ }^{5,6}$

Os polímeros termoplásticos são materiais sólidos à temperatura ambiente, mas quando aquecidos tornam-se fluidos e possíveis de ser moldados. Eles geralmente possuem baixa densidade, boa aparência, são isolantes térmicos e elétricos, resistentes ao impacto e de baixo custo, ou seja, possuem uma ampla aplicabilidade. ${ }^{6}$ Já os polímeros termofixos amolecem uma única vez, mediante aplicação de uma quantidade de calor, e depois endurecem irreversivelmente. Quando um polímero termofixo endurece se torna insolúvel em solventes. ${ }^{5,7}$

As principais vantagens dos polímeros são: suscetibilidade à coloração (pigmentação); facilidade de produção em grande escala; e imunes à corrosão. Quanto às desvantagens, alguns polímeros possuem fraca resistência aos esforços por tração, compressão, impacto, dilatação e deformação. ${ }^{5}$

Os polímeros são usados em todas as áreas no cotidiano da humanidade, incluindo roupas, eletrônicos, produtos de saúde, brinquedos e embalagem. ${ }^{8} \mathrm{De}$ acordo com a publicação anual da Associação Brasileira de Indústria Plástica (ABIPLAST) perfil 2013, a produção de plásticos no Brasil em 2012 foi de 6 milhões de toneladas, e isso representa $2,0 \%$ da produção mundial. ${ }^{9}$

Atualmente, os pesquisadores dedicam-se à melhoria das qualidades físicas e mecânicas, com o objetivo de tornar esses materiais mais competitivos, tanto em preço como em qualidade, com os materiais tradicionais. ${ }^{5,7}$

\subsubsection{MATERIAIS COMPÓSITOS}

Os compósitos são materiais obtidos pela combinação de duas ou mais substâncias que tenham alguma reatividade entre elas, que são combinadas com o 
objetivo de formar materiais com melhores propriedades que as encontradas nos materiais de origem. ${ }^{10}$ Alguns compósitos são formados pela combinação de matrizes termoplásticas e fibras lignocelulósicas, e, dependendo de sua compatibilidade, algumas fibras passam por um processo de modificação para aumentar sua reatividade com a matriz polimérica. ${ }^{11,12}$

\subsubsection{REAÇÕES DE POLIMERIZAÇÃO}

As reações de polimerização podem ser classificadas de acordo com o mecanismo de crescimento de cadeia em dois principais grupos: poliadição (polimerização em cadeia) e policondensação (polimerização de etapas), que podem se diferenciar pela relação entre o seu tamanho da cadeia polimérica formada e conversão da reação. A poliadição resulta da adição sucessiva de monômeros, ou seja, é a soma dos monômeros para formação da cadeia polimérica. $\mathrm{Na}$ policondensação, o polímero formado resulta da reação entre grupos funcionais de monômeros multifuncionais, apresentando como característica uma reação cadeiacadeia. A organização estrutural de polímeros termoplásticos ou termofixos, depende fundamentalmente da natureza dos reagentes empregados e do mecanismo de polimerização. ${ }^{5,13}$

$O$ processo escolhido e o tipo de reator também podem interferir na estrutura do polímero, bem como a natureza do monômero e o estado físico do sistema. A produção de polímeros na forma de partículas (micro ou nanométricas) usando processos de polimerização heterogêneos como emulsão, massa-suspensão, dispersão, miniemulsão, microemulsão e suspensão, facilita a manipulação desses materiais. ${ }^{14}$

\subsubsection{TIPOS DE POLIMERIZAÇÃO}

\subsection{POLIMERIZAÇÃO EM MASSA}

Nessa técnica, apenas o monômero e a espécie ativa (radical de iniciador, cátion, ânion, etc.) estão presentes no meio reacional, desta forma o meio reacional se caracteriza como um meio homogêneo com alto grau de pureza. Como a reação é exotérmica pode haver dificuldades no controle da temperatura. A agitação do meio reacional é necessária para garantir uma dispersão uniforme da massa reacional e favores uma distribuição de calor apropriada, evitando superaquecimento e problemas de coloração no polímero final. Devido à elevação de viscosidade do 
meio reacional como o resultado do crescimento das cadeias poliméricas, a conversão do meio reacional é geralmente limitada a uma faixa entre $30 \%$ a $50 \%$, caso contrário o polímero final apresentaria aspecto de bloco. ${ }^{5}$

\subsection{POLIMERIZAÇÃO EM SUSPENSÃO}

Essa técnica reúne as vantagens do processo de polimerização em massa, solução e emulsão, e busca eliminar suas desvantagens, como por exemplo, limitações de transferência de calor e massa. Pode-se dizer que a polimerização em suspensão é uma polimerização em massa dentro de cada gotícula de monômero dispersa no meio aquoso, cujas características podem representar um aumento na concentração e a velocidade da reação. ${ }^{14,15,16,13}$

Nesse tipo de polimerização, o monômero é usado em suspensão em água junto com um iniciador solúvel no monômero. Quando a mistura é agitada, a massa monomérica é dispersa em pequenas gotas micrométricas, englobando o iniciador. É também adicionado um protetor coloidal (agente de suspensão) para manter as gotas do monômero em suspensão estável e separadas, enquanto a reação não termina. Ao fim da reação, o polímero é encontrado na forma de pequenas pérolas. O peso molecular é geralmente elevado. ${ }^{5} \mathrm{O}$ tamanho médio das partículas formadas está entre $20 \mu \mathrm{m}$ e $500 \mu \mathrm{m}$, dependo da taxa de cisalhamento do meio reacional, cuja separação é relativamente fácil. O tamanho médio de partícula e sua distribuição de tamanho pode ser controlado através da velocidade da agitação (taxa de cisalhamento) e da concentração de agente de suspensão. As gotas se transformam em pequenas esferas sólidas depois de passarem por um estado de elevada viscosidade até alcançarem o ponto de identificação de partícula (PIP), que representa uma condição tal que as partículas poliméricas adquirem a sua forma rígida final, não mais modificada pela ação de quebra (cisalhamento) e coalescência. O equilíbrio entre as taxas de coalescência e quebra define a estabilidade do processo. ${ }^{14,15}$

Com o objetivo de minimizar a ação da coalescência (união) e da quebra de gotas durante a polimerização, agentes estabilizantes são usados em pequenas quantidades. O poli(álcool vinílico) - PVA é um dos mais utilizados em processos de polimerização em suspensão. A eficiência do PVA sobre a estabilidade do meio reacional, depende fundamentalmente de características como o peso molecular e o seu grau de hidrólise, referente a percentagem de radicais acetil substituídos por 
radicais hidroxila durante sua reação de hidrólise do polímero precursor poli(acetato de vinila). ${ }^{14,16}$

Como citado anteriormente, além dos agentes estabilizantes, também são utilizados iniciadores solúveis na fase orgânica. Sua percentagem de utilização então entre 0,1 e 0,5 \% em peso de monômero. Sua escolha depende da solubilidade no monômero. No caso da polimerização em suspensão os iniciadores mais utilizados são os peróxidos orgânicos ${ }^{17}$ e azocompostos. ${ }^{14,13}$

\subsection{POLIMERIZAÇÃO EM MASSA-SUSPENSÃO}

É um processo com características típicas de polimerização em suspensão e massa, caracterizado por ser um processo de polimerização conduzido em duas etapas: a primeira é típica da polimerização em massa, cuja conversão de monômero é limitada a uma faixa entre 25 \% - 50 \% devido às restrições severas ao mecanismo de transferência de calor. A segunda etapa, de comportamento típico de polimerização em suspensão, é caracterizada pela dispersão da mistura reacional viscosa em solução aquosa, contendo agente de suspensão, sob agitação vigorosa. $^{14}$

Para a obtenção de compósitos poliméricos - cuja carga particulada apresente diferença acentuada de densidade em relação ao monômero - esse processo de polimerização é o mais recomendado, o que favorece a incorporação e a dispersão apropriada dos materiais escolhidos principalmente na primeira etapa da reação. Isso beneficia a obtenção de materiais com propriedades finais melhoradas. $^{18}$

\subsubsection{POLIESTIRENO}

O monômero de estireno é um composto aromático simples. Foi isolado pela primeira vez por Neuman, no fim do século XVIII. Um farmacêutico alemão chamado Simon, em 1839, observara que o estireno solidificava durante o armazenamento ou quando aquecido, e só em 1845, Blyth e Hoffman consideraram que o observado por Simon era um processo de polimerização. Em 1866 Berthelot relatou a síntese do estireno pelo processo da passagem do benzeno e do etileno por um tubo aquecido à rubro. ${ }^{5,7}$

Sua produção comercial começou por volta de 1925 na Alemanha e nos Estados Unidos. Em 1939, com o início da guerra, houve um grande aumento na 
demanda de estireno para a fabricação de SBR (copolímero de estireno/butadieno) para a produção de equipamentos bélicos. Durante os anos seguintes houve altos e baixos na produção. Hoje representa uma das maiores indústrias do mundo. ${ }^{5}$

\subsubsection{ESTRUTURA E PROPRIEDADES}

O poliestireno é um termoplástico incolor, transparente e com um som tipicamente metálico quando cai sobre uma superfície dura. Sua resistência à tração é elevada $\left(450 \mathrm{~kg} / \mathrm{cm}^{3}\right.$ a $\left.700 \mathrm{~kg} / \mathrm{cm}^{3}\right)$ e tem elevado índice de refração $(1,59)$. Amolece a cerca de $90^{\circ} \mathrm{C}-95^{\circ} \mathrm{C}$ e a $140^{\circ} \mathrm{C}$ exibe fluidez, o que é excelente para moldagem por injeção. É quebradiço, mas pode ser reforçado com borracha para aplicações mais severas, que exijam boa propriedade de impacto. ${ }^{5,19,20}$

Possui potencial elétrico baixo, alta constante dielétrica e resistividade volumétrica. É resistente a ácidos fortes e álcalis, é insolúvel em hidrocarbonetos alifáticos. É solúvel em ésteres, hidrocarbonetos aromáticos e clorados. São fáceis de trabalhar e resistentes ao calor. ${ }^{5,21} \mathrm{O}$ poliestireno tem a seguinte fórmula representativa (Figura 1).

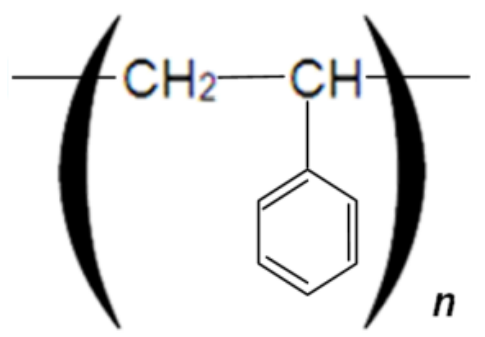

Figura 1: Estrutura representativa do poliestireno. ${ }^{5}$

Após o processo de polimerização, o poliestireno obtido via radicais livres é amorfo, devido a natureza volumosa dos anéis de benzeno. Como se vê na estrutura acima, os anéis não permitem uma maior aproximação das cadeias poliméricas, resultando em um arranjo ao acaso das cadeias macromoleculares. Isso é observado quando comparado com a elevada cristalinidade que se obtêm com polímeros quase lineares, como o polietileno. ${ }^{5}$

Poliestirenos semi-cristalinos são obtidos via catálise estereoquímica, que obrigam os grupos benzênicos a assumir um arranjo regular ao longo da cadeia principal com elevado grau de orientação interna. ${ }^{5,20}$ 


\subsubsection{APLICAÇÕES}

O poliestireno, devido as suas propriedades elétricas, é bastante utilizado na indústria elétrica e eletrônica. Os tipos mais resistentes ao calor são usados para fabricação de embalagens térmicas e aqueles resistentes ao impacto servem para a fabricação de jarras e copos. Nos casos em que a resistência ao calor não é essencial, mas se requer uma estrutura de elevado peso molecular, resistência à flexão e ao choque, são usados para fabricação de escovas de dente, caixas e potes em todas as cores e com alto brilho. Tampas de garrafas, artigos domésticos, cabides, pentes e brinquedos também são fabricados com poliestireno reforçado, cuja fragilidade é muito menor. ${ }^{5,7}$

$\mathrm{Na}$ construção civil, o poliestireno é largamente utilizado, uma vez que origina peças com superfícies brilhantes e polidas. O poliestireno de alto impacto (HIPS, do inglês High Impact Polystyrene) é utilizado em materiais sanitários, pois graças à incorporação de uma fase elastomérica à matriz termoplástica do poliestireno confere ao material final excelentes propriedades mecânicas, tornando-o quase inquebrável sem sofre alterações devido a ação de produtos químicos. Adicionalmente, é possível à adição de essências aromáticas, tornando os produtos perfumados. $\mathrm{O}$ isopor (forma expandida do poliestireno) pode ser aplicado em pisos flutuantes, no interior de paredes divisórias, decoração, forros, isolamento acústico e térmico. ${ }^{7}$

\subsection{LIGNINA}

A expressão lignina é originária da palavra em latim lignum, que significa madeira. Estudos realizados há 150 anos concluíram que a lignina é amorfa, de natureza aromática e complexa, tornando-se interessante cientificamente e economicamente. Devido à grande variedade de sua estrutura, alguns pontos ainda causam dúvida, pois há diferenças entre espécies e até mesmo dentro da mesma espécie, quando analisadas as diferentes partes da planta (paredes externas ou internas). ${ }^{22,23,24}$

Originalmente a lignina foi descoberta por Anselme Payer em 1838 após o tratamento da madeira com ácido sulfúrico. Peter Klason estudou em 1897 a composição de lignosulfonados, provenientes da polpação da madeira, e lançou a ideia que a lignina está relacionada com o álcool coniferílico. ${ }^{25,23}$ 
A madeira é composta de três principais constituintes: celulose, lignina e hemicelulose. A celulose está embutida dentro de uma matriz de hemicelulose e lignina como mostrado na Figura 2., 26, 25, 27, 28

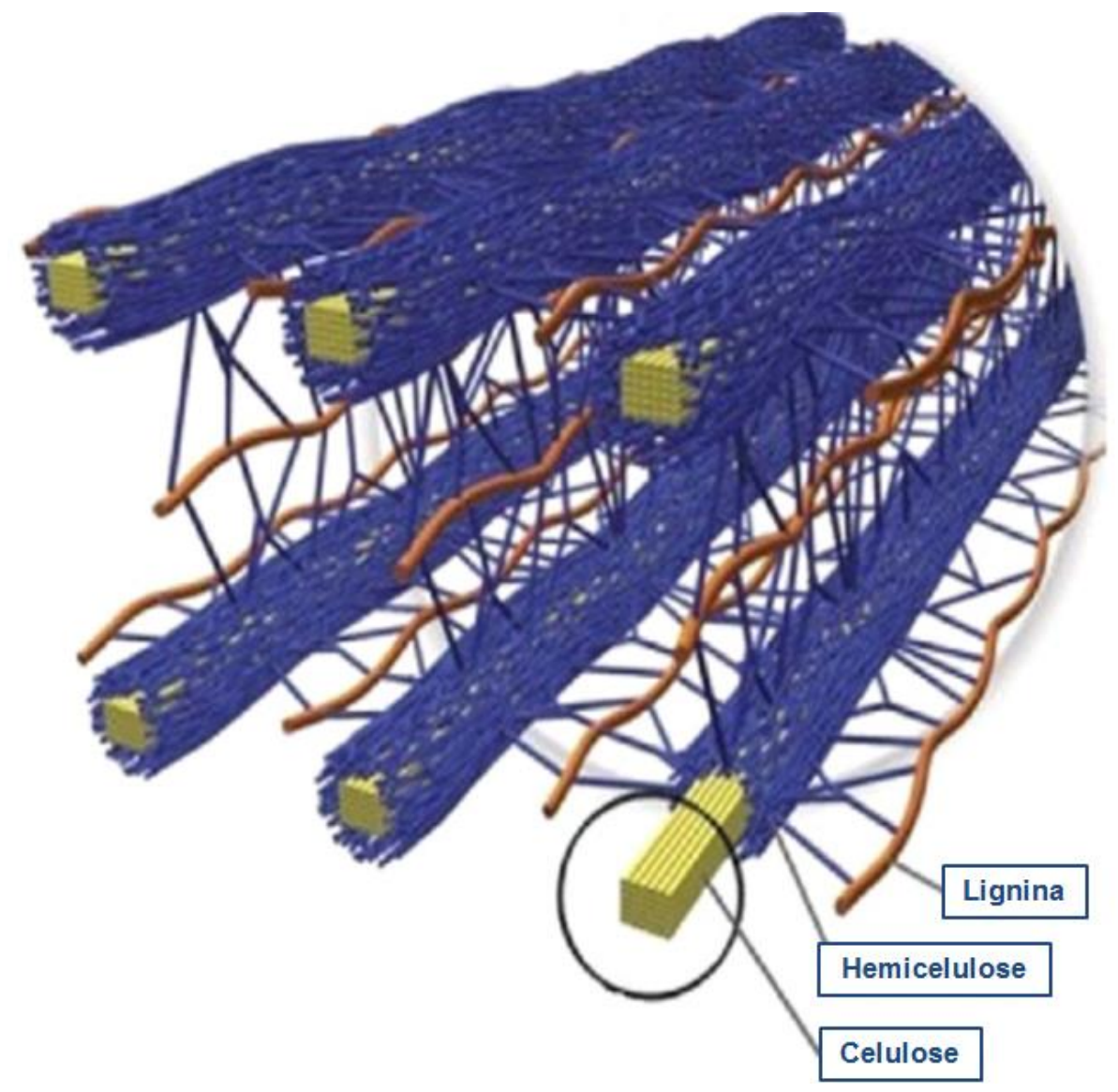

Figura 2: Celulose rodeada por hemicelulose e lignina. Adaptada de Doherty et al. ${ }^{26}$

Como parte da estrutura, a lignina age como "cola" preenchendo os espaços entre e em torno da celulose e hemicelulose, por isso tem o papel de suporte na estrutura da biomassa sendo responsável por sua rigidez. ${ }^{27,}$ 29, 25, 22, 30, 31

A maioria das plantas possui lignina, mas, sua composição e estrutura não é igual em todas, por exemplo, madeiras de fibras longas (coníferas), madeiras de fibras curtas (folhosas) e gramíneas possuem lignina com estruturas bem diferentes. Já as plantas aquáticas, angiosperma, herbáceas e manocotiledôneas possuem baixos teores de lignina em sua estrutura. ${ }^{25,32}$

A lignificação ocorre com o desenvolvimento do sistema de condução da água e também como uma necessidade da árvore de suportar sua copa a muitos metros de altura. Possui também o papel como agente selante e é considerada como um mecanismo de descarga dos lixos metabólicos. ${ }^{27} \mathrm{~A}$ lignina, no desenvolvimento das plantas, é incorporada como o último componente da parede enrijecendo-as. É 
responsável pelo transporte de nutrientes, resistência mecânica e proteção contra ataques de microrganismos. ${ }^{25}$

\subsubsection{COMPOSIÇÃO E ESTRUTURA}

A lignina é um polímero natural e complexo formado por macromoléculas tridimensionais de origem fenilpropano e representa cerca de $30 \%$ da biomassa. Contudo ela não ocorre sozinha na natureza e é impossível de ser removida quantitativamente da estrutura da madeira sem considerável degradação. Basicamente, ela é um polímero aromático com sistemas heterogêneos e ramificados sem repetição de unidades definidas. ${ }^{33}$

A lignina se encontra principalmente em regiões escuras da madeira e sua estrutura pode ser estudada pelos produtos de decomposição. Sua composição elementar é 53 - $65 \%$ de carbono, 6 - 9 \% de hidrogênio e 26 - $36 \%$ de oxigênio. Em sua forma natural não apresenta enxofre, fósforo, nitrogênio ou outros elementos. ${ }^{31,34}$

Três estruturas formam a base da macromolécula da lignina: $p$-hidroxifenila $(\mathrm{H})$ derivada do álcool p-cumarílico, Guaiacila $(G)$ derivada do álcool coniferílico e a Siringila (S) do álcool sinapílico (Figura 3). Para a formação da lignina ocorrem ligações entre os átomos de carbono da lateral do propano, no núcleo aromático e na hidroxila fenólica. A ligação entre as unidades de fenilpropano do tipo $\beta$-O-4 (éterarila) é a principal. Outros tipos também podem ocorrer, como as ligações 4-O-5, 1O-4, $\alpha-0-4,5-5,1-5, \beta-1, \beta-5, \beta-\beta$ e as ligações condensadas nos carbonos 2 e $6{ }^{29,}$ $31,33,35,23$

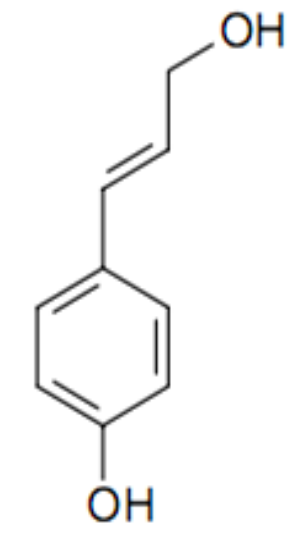

Álcool p-cumarilico

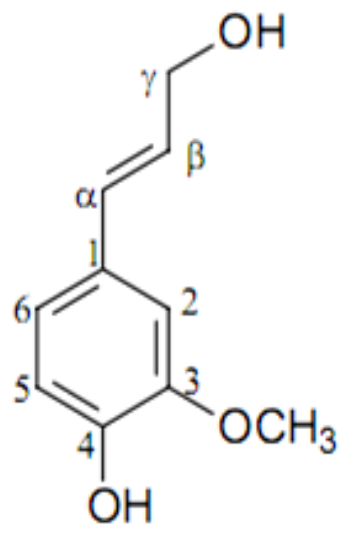

Álcool coniferilico

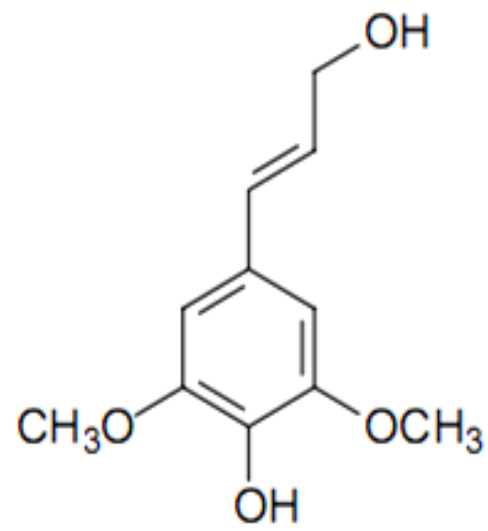

Álcool sinapilico

Figura 3: Estruturas primárias da lignina. ${ }^{29}$ 
Os grupos funcionais mais importantes são: metoxila, hidroxila, carboxila, éter, éster e carbonilas aromáticas ou alifáticas. ${ }^{25}$ A Figura 4 representa uma estrutura da lignina de madeira de faia (Fagus silvatica) proposta por Nimtz. ${ }^{25}$

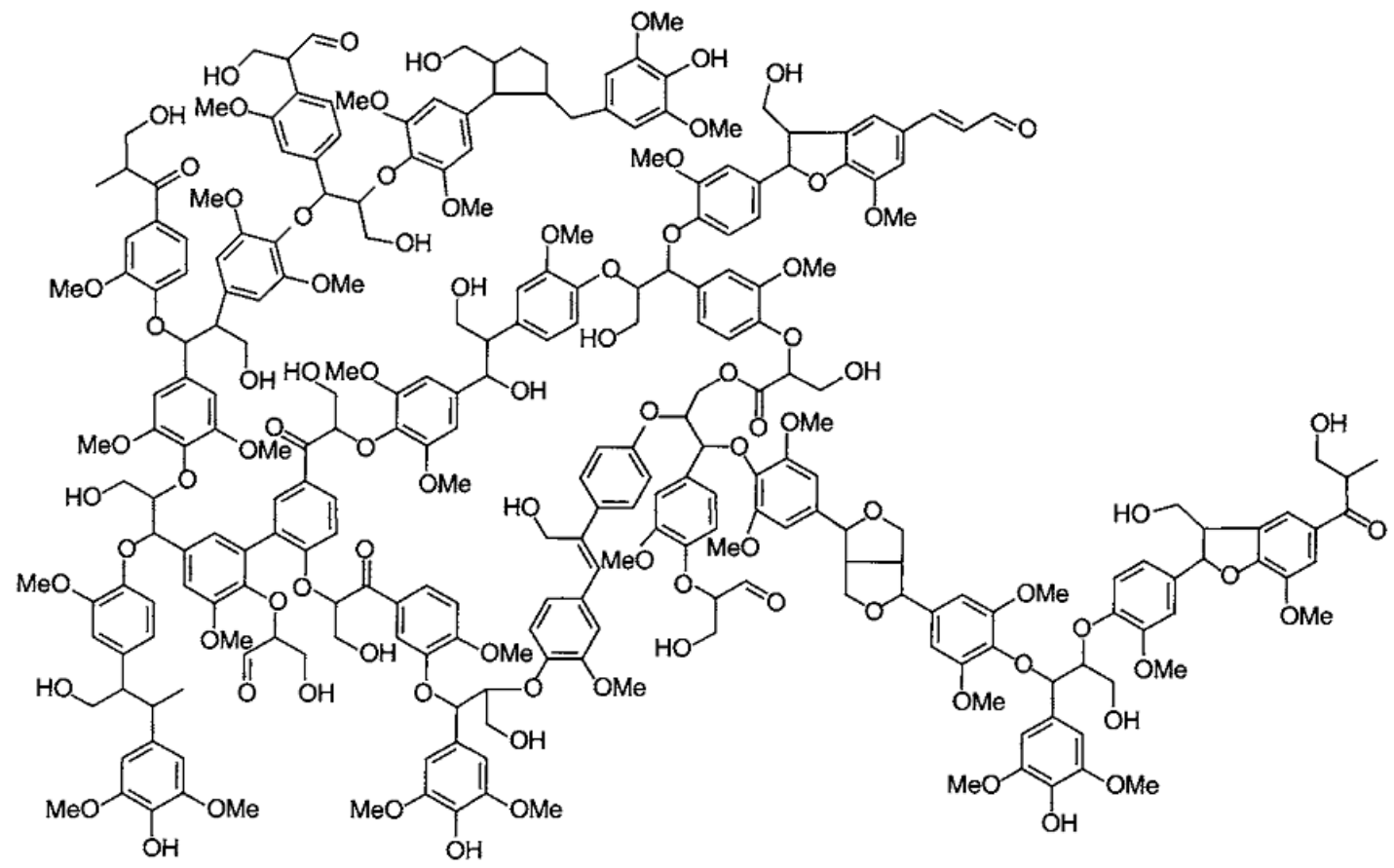

Figura 4: Estrutura da lignina, proposta por Nimtz. ${ }^{35,25}$

A quantificação dos componentes da estrutura química da lignina é importante para o posterior aproveitamento, pois ela é obtida em grande escala no mundo, geralmente como subproduto do processo de polpação nas indústrias de papel, sendo seu principal aproveitamento como fonte de energia. Contudo parte ainda acaba sendo descartada como rejeito. ${ }^{3}$

\subsubsection{MÉTODOS DE SEPARAÇÃO DOS COMPONENTES LIGNOCELULÓSICOS}

Há diferentes métodos de separação e nenhuma delas permite obter os componentes lignocelulósicos como se encontra na natureza, pois sempre haverá influências dos processos de extração. Os procedimentos mais adequados envolvem a moagem do material em moinhos, geralmente de facas ou bolas, e depois a extração com solvente. O objetivo principal é a separação da lignina dos outros componentes fibrosos. $\mathrm{O}$ método escolhido e a fonte influenciam significativamente a composição final e propriedades dos materiais obtidos. Boa parte dos processos de 
separação ou deslignificação ocorrem por tratamentos com ácidos ou mecanismos catalisados por bases. ${ }^{3,22,36,35,26}$

Os principais métodos são:

- Método Klason, onde os polissacarídeos (celulose e hemicelulose) são removidos por hidrólise ácida e a lignina é liberada como resíduo. ${ }^{22,37}$

- Processo Organossolve, onde álcoois (metanol, isobutanol, ciclo hexanol ou álcool benzílico) são combinados com a lignina na presença de ácidos (ácido acético, geralmente). O rendimento desse processo é de aproximadamente $30 \% .^{22,38,39}$

- Lignina sulfítica e a Kraft, também conhecida como sulfática. A sulfítica é produzida pela reação da madeira com hidróxido de sódio e sulfito de sódio; e a sulfática pela reação da madeira com sulfeto de sódio em meio básico. ${ }^{22,40}$

- Lignina Nativa ou de Brauns: inicialmente a extração é feita com éter, depois com água fria e em seguida com etanol 95 \%. Após a extração, a lignina é precipitada com adição de água. O rendimento é muito baixo, cerca de $2 \%$ a $4 \%$ da lignina é recuperada. ${ }^{22,41}$

- Lignina de Madeira Moída: é a mais utilizada nos estudos da estrutura da lignina, devido a habilidade de extrair ligninas sem grandes transformações químicas. Nesse processo a madeira, finamente moída em moinho de bolas por três dias e livre de extrativos, é tratada com uma mistura de dioxano-água (9:1) ou acetona-água (9:1) resultando em uma solução contendo lignina, que é purificada com $\mathrm{NaOH} 0,1 \mathrm{~N}$ e precipitada com $\mathrm{HCl} 0,3 \mathrm{~N}$. O rendimento desse processo é de aproximadamente $50 \%{ }^{22}$

A explosão de vapor é também outro método que promove a separação dos componentes lignocelulósicos por meio de impregnação de vapor sob compressão, seguida de rápida descompressão. Esta descompressão provoca quebras estruturais mais acentuadas no material. A lignina é precipitada pela adição de soluções diluídas de $\mathrm{NaOH} .^{42}$

\subsubsection{LIGNINA KRAFT}

O processo Kraft é um processo de polpação alcalina dominante e mais utilizado, sendo base para vários processos de modificação da lignina. $\mathrm{O} N \mathrm{NaH}$ 
(hidróxido de sódio) é o principal produto químico utilizado, juntamente com $\mathrm{Na}_{2} \mathrm{~S}$ (sulfeto de sódio). A pressão e o tempo de cozimento variam de 7 - 10 bar e de 0,5 - $2 \mathrm{~h}$, respectivamente, dependendo de parâmetros como o tipo de polpa a ser produzida. ${ }^{25,35,23}$

A alcalinidade inicial deve ser alta o suficiente para manter um $\mathrm{pH}$ acima de 9 ao final do processo, com o intuito de garantir a dissolução e evitar a sedimentação da lignina. O ponto principal do processo Kraft é o rompimento das ligações devido o ataque químico pelos solutos alcalinos, aumentando relativamente ao final, os grupos hidroxílicos na estrutura da lignina. ${ }^{27}$

A grande utilização desse processo deve-se à: baixa exigência quanto a qualidade da matéria-prima; curto tempo de cozimento; geração de calor para as caldeiras com a queima da lignina; e produção de polpa de excelente qualidade e resistência. Contudo há inconveniências como: odor desagradável, principalmente causado por derivados do enxofre; baixo rendimento de polpa (45 a $55 \%$ ); e custos significativos para instalação de fábricas. ${ }^{25,36}$

Quase toda lignina extraída pelo processo Kraft em indústrias é queimada para geração de energia, mas uma pequena parte é recuperada e vendida na forma de pó. ${ }^{25,23}$

\subsubsection{MODIFICAÇÃO DA LIGNINA E SOLUBILIDADE}

A lignina, tendo em vista sua natureza, não é solúvel na maioria dos solventes orgânicos, contudo são solúveis em bases aquosas quentes e estável em soluções de ácidos minerais. A modificação química da lignina tem como objetivo principal aumentar sua hibrofobicidade, e consequentemente favorecer sua dispersão em solventes orgânicos. ${ }^{33}$

O aumento da cadeia alifática do carbono por meio da substituição de grupos hidroxila por grupos ésteres (Figura 5) na lignina pode reduzir sua polaridade e aumentar sua solubilidade em solventes apolares. A modificação com a introdução de duplas ligações, com anidridos maleico e metacrílico provocam uma redução na temperatura de transição vítrea da lignina e aumento significativo de sua solubilidade em solventes orgânicos, o que permite uma melhora nas propriedades mecânicas quando usada em matrizes poliméricas. ${ }^{35,43,44,45}$ Os componentes mais comumente usados nessa modificação podem ser anidridos acético, propanoico, butílico, maleico 
e metacrílico. Dentre estas, a lignina modificada com anidrido metacrílico é a mais atrativa para uso em reações de polimerização via radicais livres. ${ }^{25}$

Há uma grande variedade de anidridos ácidos que permitem a adição de cadeias laterais diferentes para alcançar a solubilidade em vários solventes. Para essas reações há catalisadores mais eficazes que outros, por exemplo, o 1 -metilimidazol é 400 vezes mais reativo que a piridina nas reações com anidridos. ${ }^{35}$, $46,47,48$

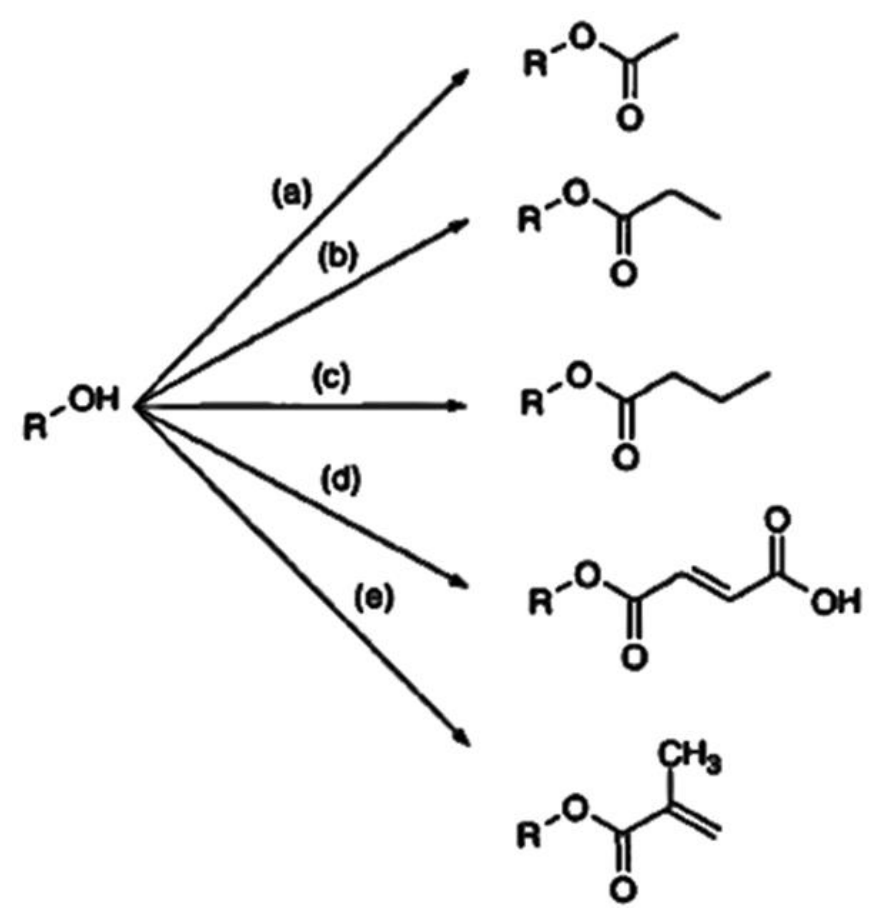

Figura 5: Conversão de grupos hidroxilas em ésteres. (a) acético, (b) propanóico, (c) butílico, (d) maléico, e (e) metacrílico. ${ }^{25}$

A acetilação torna a lignina solúvel em uma variedade de compostos orgânicos tais como acetona, tetrahidrofurano e clorofórmio, sendo usada para técnicas de caracterização, como RMN. Quando a lignina é sulfonada pode reagir com extremidades polares hidrofílicas, e consequentemente, ser usadas como dispersante sólido em água. Esses estudos são geralmente voltados para o desenvolvimento de plásticos biodegradáveis polares, tais como plásticos de proteína de soja. ${ }^{35,39,44}$

\subsubsection{MATERIAIS PRODUZIDOS COM LIGNINA}

A lignina é um exemplo de material oriundo de biomassa que pode ser utilizado na preparação de novos materiais como, enxerto de poliuretanas, 
mostrando um melhoramento em suas propriedades reológicas, pois em relação ao polímero puro, o enxerto de até $15 \%$ de lignina mostrou um melhor escoamento e recuperação de viscosidade. Contudo os compósitos formados com lignina acima de $30 \%$ eram rígidos e quebradiços, mesmo com a adição de plastificantes ${ }^{\dagger}$, devido à ligações cruzadas e o aumento do peso molecular. ${ }^{43}$

O uso de lignina para a produção de fibras de carbono tem se mostrado promissor. Os quais podem ser usados como eletrodos, pois as ligações entre as fibras melhoram as propriedades elétricas do material, aumentando sua condutividade elétrica. Esse material tem potencial para substituir eletrodos em baterias, células solares e capacitores. A técnica utilizada para produção de fibras interligadas de carbono a base de lignina também mostrou um aumento da resistência a tração devido a ligações entre as fibras. ${ }^{51}$

Sua utilização também é baseada no caráter dispersante e adesivo, sendo aplicada em pigmentos, produtos cerâmicos, pesticidas, emulsificantes de óleos e látex, aditivo de concreto e cimento. ${ }^{36}$

$\mathrm{Na}$ área da biomedicina, a lignina pode ser combinada a polímeros condutores para produzir materiais antioxidantes capazes de reduzir o stress oxidativo do tecido biológico. ${ }^{28}$

\footnotetext{
${ }^{\dagger}$ Plastificantes são aditivos utilizados em polímeros para modificar suas propriedades, principalmente a temperatura de transição vítrea $\left(\mathrm{T}_{\mathrm{g}}\right)$, o módulo de elasticidade e alongamento na ruptura, com o objetivo de obter materiais mais flexíveis. ${ }^{49,50}$
} 
CAPÍTULO 3

MATERIAL E MÉTODOS 


\subsection{REAGENTES}

Nessa pesquisa foram utilizadas amostras de madeira de eucalipto das espécies Eucalytpus Gandis, resultante do cruzamento do Eurogandi e Urophylla, de aproximadamente cinco anos e plantadas em Ponta Porã - MS, moída em Moinho de Facas tipo Willey Fortinox Star FT-60.

Para a determinação do teor de lignina foram utilizados: ácido sulfúrico $\left(\mathrm{H}_{2} \mathrm{SO}_{4}\right)$, com pureza de $98 \%$ e fornecido pela J.T. Baker; e água destilada.

$\mathrm{Na}$ extração da lignina foram utilizados: hidróxido de sódio $(\mathrm{NaOH})$ em micropérolas, com pureza de $99 \%$ fornecido pela Vetec; acetona, grau P.A, fornecida pela Neon; ácido clorídrico $37 \%(\mathrm{HCl})$, com pureza P.A., fornecido pela Fluka; e água destilada.

Nas reações de polimerização foram utilizados estireno com pureza de $99 \%$, fornecido pela Spectrum; peróxido de benzoíla (BPO, LUPEROX 78), com pureza de $75 \%$ contendo $25 \%$ de água como estabilizante e com oxigênio ativo de $5 \%$ doado pela Arkema; poli(álcool vinílico) (PVA, DENKA POVAL B-24), com grau de hidrólise na faixa de 86-89 \% e pureza de $99 \%$, doado pela Denka; dodecilsulfato de sódio, fornecido pela Quimibrás; hidroquinona, fornecida pela Merk; e água destilada.

No processo de esterificação da lignina foram utilizados 1-metilimidazol com pureza de $99 \%$, fornecido pela Sigma Aldrich; anidrido metacrílico com pureza de 94 $\%$, fornecido pela Sigma; 1-4 dioxano com pureza de $99 \%$, fornecido pela Vetec, éter etílico com pureza de $99,5 \%$, fornecido pela Vetec; ciclohexano pureza de $99 \%$ fornecido pela Vetec e água deionizada.

Para a análise de RMN ${ }^{1} \mathrm{H}$ foi utilizado o dimetil sulfóxido deuterado (DMSO) com $99,9 \%$ de pureza,e fornecido pela Sigma Aldrich.

Todos os produtos químicos foram utilizados como recebidos, sem a necessidade de purificação adicional.

\subsection{MÉTODOS}

\subsubsection{DETERMINAÇÃO DO TEOR DE LIGNINA NA MADEIRA}

Para determinação de lignina da madeira de eucalipto foi utilizado o método Klason descrito por Gouveia, ${ }^{52}$ onde $1 \mathrm{~g}$ madeira moída é pré-tratada com $5 \mathrm{~mL}$ de ácido sulfúrico $72 \% \mathrm{v} / \mathrm{v}$, sob vigorosa agitação por 7 min a $45 \stackrel{\circ}{\circ}$, em um banho termostatizado. Depois, a mistura foi transferida para um erlenmeyer de $250 \mathrm{~mL}$, 
adicionando-se o volume de $125 \mathrm{~mL}$ de água destilada e autoclavados durante 30 min a $121^{\circ} \mathrm{C} / 1 \mathrm{~atm}$. Após resfriamento, a fração sólida é separada por filtração em papel filtro. $O$ material retido no filtro é lavado com $2 L$ de água destilada e seco em estufa a $100^{\circ} \mathrm{C}$. A amostra é então calcinada para determinação de cinzas. Com os dados obtidos é possível determinar a percentagem de lignina insolúvel em relação à massa de amostra inicial. ${ }^{52}$

\subsubsection{EXTRAÇÃO DA LIGNINA PELO MÉTODO KRAFT MODIFICADO}

No Método Kraft Modificado, para o cozimento, foi utilizado $\mathrm{NaOH} 15 \%$ na proporção de $5 \mathrm{~mL} / 1 \mathrm{~g}$ de madeira moída. A solução foi autoclavada durante uma hora a $120^{\circ} \mathrm{C} / 1 \mathrm{~atm}$. Após o cozimento a solução é filtrada e lavada com água quente. O filtrado, rico em lignina denominado Licor Negro, foi tratado com uma solução de $\mathrm{HCl} 10 \%$ para a precipitação de lignina. A lignina é separada da solução em centrífuga refrigerada e seca em estufa a $50{ }^{\circ} \mathrm{C} .{ }^{22}$

\subsubsection{EXTRAÇÃO DA LIGNINA PELO MÉtOdO KRAFT COM PRÉ- TRATAMENTO COM ACETONA}

Nesse método foi utilizado uma solução de acetona e água $(1: 1 \mathrm{v} / \mathrm{v})$ na proporção de $10 \mathrm{~mL} / \mathrm{g}$ de madeira moída. A mistura foi autoclavada durante 20 minutos a $120 \stackrel{\circ}{\circ} / 1 \mathrm{~atm}$. Após o cozimento acrescentou-se $20 \mathrm{~mL}$ de água destilada, e então a mistura resultante foi filtrada e lavada com água quente. Após esse prétratamento a parte que ficou retida no filtro foi colocada novamente em béqueres e seguiu o método Kraft modificado como descrito anteriormente. ${ }^{38,53}$

\subsubsection{PROCESSO DE POLIMERIZAÇÃO EM MASSA-SUSPENSÃO}

As reações de polimerização via massa-suspensão foram realizadas em reator de vidro de borossilicato encamisado e capacidade de $250 \mathrm{~mL}$, equipado com condensador acoplado com água corrente $\left(20^{\circ} \mathrm{C} \leq \mathrm{T} \leq 25^{\circ} \mathrm{C}\right)$. $\mathrm{O}$ agitador mecânico foi equipado com impelidor para garantir a agitação da mistura reacional (Figura 6). ${ }^{18}$

Antes do processo de polimerização em massa-suspensão, com o objetivo de aumentar a compatibilidade entre a lignina natural ou esterificada e o estireno, um estágio de acondicionamento foi realizado, ou seja, um contato prévio entre os constituintes da reação de polimerização, durante 12 horas sob agitação vigorosa e temperatura ambiente. ${ }^{18}$ 


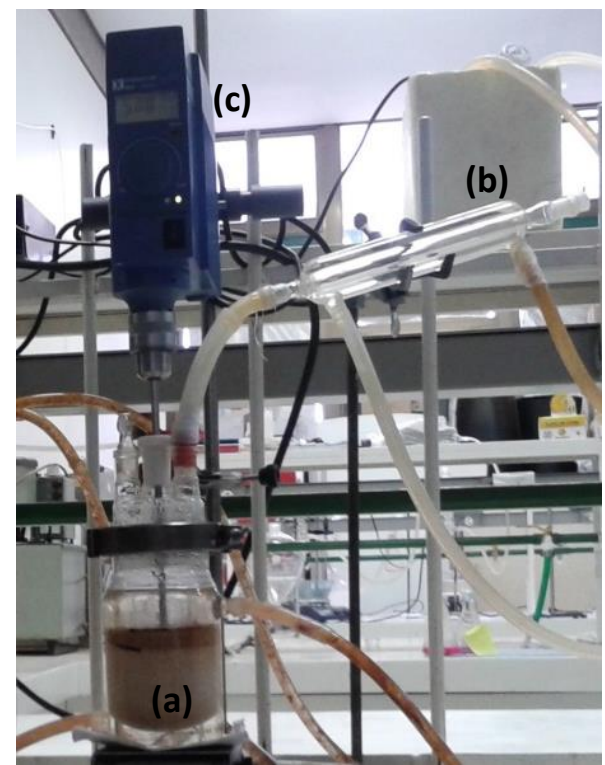

Figura 6: Sistema reacional utilizado para as reações de polimerização massa-suspensão de estireno/lignina e estireno/lignina esterificada. Onde; (a) reator de borossilicato de $250 \mathrm{~mL}$, (b) condensador, (c) agitador mecânico com impelidor.

A polimerização foi realizada em duas etapas principais, conduzidas de forma sequencial:

1) polimerização em massa, caracterizada pela dispersão de partículas de lignina natural ou esterificada, de aproximadamente $75 \mu \mathrm{m}$, em estireno. A reação foi mantida sob agitação constante de $1.000 \mathrm{rpm}$ a $85{ }^{\circ} \mathrm{C}$ até que a conversão de $50 \%$ fosse alcançada (aproximadamente 2 horas). ${ }^{18} \mathrm{~A}$ Tabela 1 mostra a composição da mistura reacional utilizando a proporção de estireno/lignina natural ou esterificada para as reações com $5 \%, 10 \%$ e $20 \%$ de lignina natural e a Tabela 2 estão listados a composição da mistura reacional utilizando a proporção de estireno/lignina esterificada para as reações com $5 \%, 10 \%$ e $20 \%$ de lignina esterificada;

2) polimerização em suspensão, caracterizada pela adição da solução de PVA no meio reacional e a diminuição da agitação para $500 \mathrm{rpm}$. Esse processo foi mantido por 4 horas e aquecimento constante de $85 \stackrel{\circ}{\circ} .^{18}$ No término da reação, após resfriamento até a temperatura ambiente, a mistura foi lavada com soluções de dodecilsulfato de sódio e hidroquinona, com o objetivo de eliminar monômeros residuais e inibir a continuidade da reação. Em seguida o material foi seco em condições ambientes na capela. $^{18}$ 
Tabela 1: Composição da mistura reacional da polimerização em massa-suspensão com estireno e lignina natural.

\begin{tabular}{c|cccc}
\hline \hline Lignina natural \% & Estireno $(\mathbf{g})$ & Lignina $(\mathbf{g})$ & BPO $(\mathbf{g})$ & PVA $(\mathbf{m L})$ \\
\hline 5 & 58 & 2,9 & 2,03 & $135(5 \mathrm{~g} / \mathrm{L})$ \\
10 & 58 & 5,8 & 4,06 & $135(7 \mathrm{~g} / \mathrm{L})$ \\
20 & 58 & 11,6 & 9,0 & $135(10 \mathrm{~g} / \mathrm{L})$ \\
\hline
\end{tabular}

Tabela 2: Composição da mistura reacional da polimerização em massa-suspensão com estireno e lignina esterificada.

\begin{tabular}{c|cccc}
\hline \hline Lignina esterificada \% & Estireno (g) & Lignina $(\mathbf{g})$ & BPO $(\mathbf{g})$ & PVA $(\mathbf{m L})$ \\
\hline 5 & 58 & 2,9 & 2,03 & $135(10 \mathrm{~g} / \mathrm{L})$ \\
10 & 58 & 5,8 & 4,06 & $135(30 \mathrm{~g} / \mathrm{L})$ \\
20 & 58 & 11,6 & 9,0 & $135(50 \mathrm{~g} / \mathrm{L})$ \\
\hline
\end{tabular}

\subsubsection{DETERMINAÇÃO DE HIDROXILAS TOTAIS}

A lignina natural $(10 \mathrm{mg})$ foi dissolvida em $25 \mathrm{~mL}$ de dioxano e transferida para balões de $100 \mathrm{~mL}$. A primeira amostra é ajustada para o $\mathrm{pH}$ igual a 1, utilizando $\mathrm{HCl} 1 \mathrm{M}$, e a outra amostra é ajustada para $\mathrm{pH}$ igual a 13, utilizando $\mathrm{KOH} 1 \mathrm{M}$. Os volumes são completados com uma solução de água/dioxano $(1: 1 \mathrm{v} / \mathrm{v})$. $\mathrm{O}$ espectro na região de $250 \mathrm{~nm}$ foi obtido utilizando-se a solução com pH igual a 1 como referência e a solução com $\mathrm{pH}$ igual a 13 como amostra. O mesmo procedimento foi repetido para a lignina esterificada. ${ }^{54}$

\subsubsection{MODIFICAÇÃO DA LIGNINA NATURAL}

O método utilizado foi descrito por Thielemans e Wool. ${ }^{27} \mathrm{~A}$ reação de esterificação foi realizada a $50 \stackrel{\circ}{\circ}$, sob atmosfera de nitrogênio (com o objetivo de evitar a oxidação da lignina) e agitação vigorosa. A reação é deixada por 24 horas para assegurar uma melhor conversão. A mistura reacional consiste de $6,1 \mathrm{~mL}$ de uma mistura de anidrido metacrílico e 1-metilimidazol (60/1) e $4 \mathrm{~mL}$ de 1,4-dioxano para cada grama de lignina natural (Figura 7). ${ }^{27}$

Após 24 horas de reação foi adicionado éter etílico para parar a reação. A mistura foi lavada três vezes com água deionizada. A fase aquosa foi filtrada para remoção de todo catalisador. $O$ ciclohexano foi subsequentemente adicionado para sedimentar a lignina esterificada. O precipitado foi recuperado por filtração à vácuo e 
seco a vácuo à $60{ }^{\circ} \mathrm{C}$ por 24 horas. As quantidades utilizadas no processo final foram, para cada $100 \mathrm{~mL}$ de mistura reacional, $200 \mathrm{~mL}$ de éter etílico, $600 \mathrm{~mL}$ (3 X $200 \mathrm{~mL}$ ) de água deionizada e $200 \mathrm{~mL}$ de ciclohexano. A redução de ciclohexano reduz também o rendimento de recuperação da lignina esterificada. ${ }^{27}$

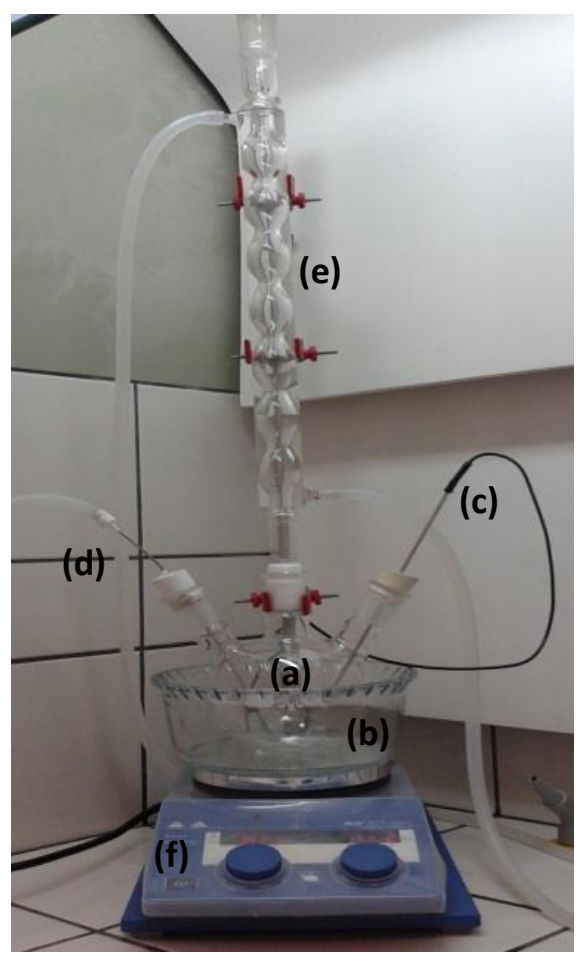

Figura 7: Sistema reacional utilizado para as reações de esterificação da lignina. Onde: (a) balão de $250 \mathrm{~mL}$, (b) banho de óleo, (c) termopar, (d) entrada de gás nitrogênio, (e) condensador de refluxo e (f) placa de aquecimento e agitação magnética.

Um exemplo de esquema para a reações de esterificação usando 1 metilimidazol está representado na Figura 8. Onde o anidrido reage com 01 metilimidazol formando 0 íon $N$-aquil- $N$ '-metilimidazol, que então reage irreversivelmente com o grupo álcool da lignina natural formando éster. ${ }^{27,55}$
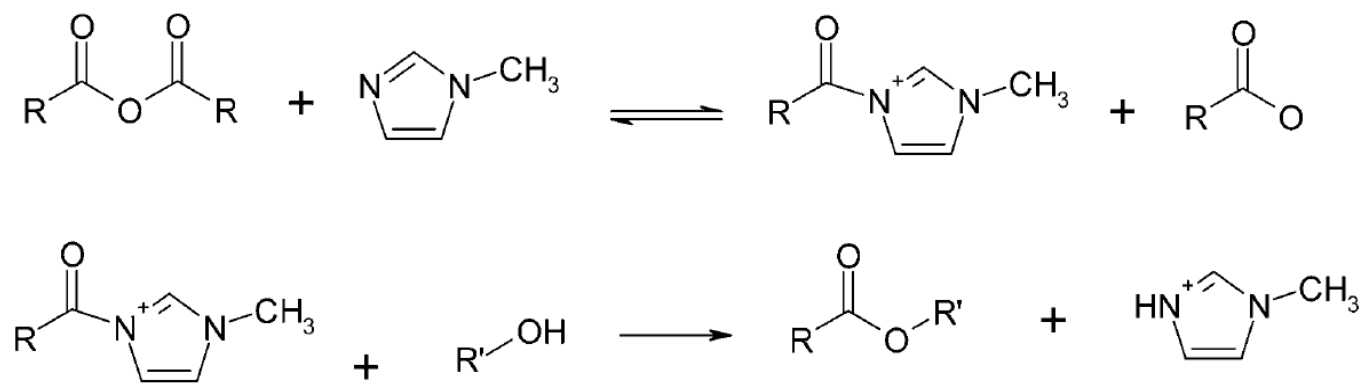

Figura 8: Esquema de reação de esterificação usando o 1-metilimidazol. ${ }^{27}$ 


\subsubsection{TESTE DE SOLUBILIDADE DA LIGNINA}

Estireno $(1 \mathrm{~g})$ e lignina natural $(0,05 \mathrm{~g})$ foram colocados em tubo de ensaio e imersos em banho de óleo a $85^{\circ} \mathrm{C}$ por 1 hora (Figura 9). Após esse período a solução foi retirada do banho e deixada para precipitar. Depois, o sobrenadante foi retirado cuidadosamente e o precipitado deixado para secar. Após 24 horas, os tubos são pesados novamente para verificar a quantidade de lignina natural que não foi solúvel em estireno. O mesmo procedimento foi repetido para a lignina esterificada. $^{27}$

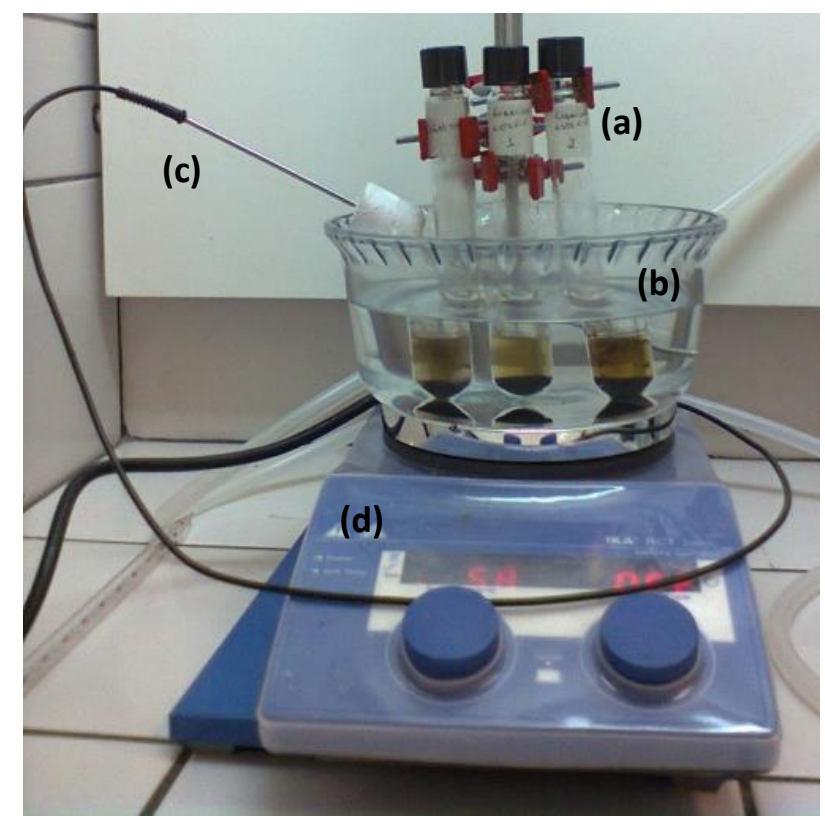

Figura 9: Sistema para teste de solubilidade da lignina natural e lignina esterificada. Onde: (a) tubos de ensaio, (b) banho de óleo, (c) termopar e (d) placa de aquecimento e agitação magnética.

\subsubsection{TÉCNICAS DE CARACTERIZAÇÃO}

\subsubsection{ESPECTROSCOPIA NA REGIÃO DO INFRAVERMELHO (IV)}

A espectroscopia IV é utilizada quase exclusivamente para caracterização qualitativa. Os espectros apresentados têm função descritiva e de confirmação da presença de grupos característicos. $^{22,56,57,58,59}$ As análises de lignina natural e lignina esterificada foram feitas em um acessório de reflectância total atenuada (ATR) em um espectrômetro FT-IR da PerkinElmer (EUA), modelo Spectrum Two com 32 varreduras. 


\subsubsection{RESSONÂNCIA MAGNÉTICA NUCLEAR (RMN)}

Cerca de $25 \mathrm{mg}$ de lignina natural foram dissolvidos em $1 \mathrm{~mL}$ de dimetilsulfóxido deuterado (DMSO) e os espectros foram adquiridos em equipamento de RMN da Bruker (EUA) modelo Ascend 600, equipado com sonda de $5 \mathrm{~mm}$ e operando a $600 \mathrm{MHz}$, os espectros foram adquiridos a $25^{\circ} \mathrm{C}$, utilizando TMS como padrão interno. O mesmo procedimento foi repetido para a lignina esterificada.

\subsubsection{ANÁLISES TÉRMICAS}

\subsection{TERMOGRAVIMETRIA (TGA)}

Essa técnica que mede a variação de massa da amostra em função da temperatura ou do tempo. A TGA é usada para caracterizar a degradação do polímero e avaliar a estabilidade térmica do material em estudo e sua cinética de degradação. ${ }^{60,57}$

Para essa análise foi utilizado um analisador termogravimétrico Shimadzu modelo DTG-60H (Shimadzu, Japão). As condições de análise foram atmosfera inerte de $\mathrm{N}_{2}$; fluxo de $30 \mathrm{~mL} / \mathrm{min}$; taxa de aquecimento de $10{ }^{\circ} \mathrm{C} / \mathrm{min}$ e intervalo de temperatura na faixa de $30{ }^{\circ} \mathrm{C}$ a $800{ }^{\circ} \mathrm{C}$ nas análises de lignina natural e lignina esterificada e na faixa de $30{ }^{\circ} \mathrm{C}$ a $500{ }^{\circ} \mathrm{C}$ nas análises de polímeros, onde, em cadinho de platina, foi pesado $10 \mathrm{mg}$ do material e introduzido no analisador. ${ }^{60}$

\subsection{CALORIMETRIA DIFERENCIAL DE VARREDURA (DSC)}

Para a análise de DSC foi utilizado um analisador termogravimétrico modelo DSC-60 (Shimadzu, Japão), onde aproximadamente $8 \mathrm{mg}$ do material foi colocada em um porta amostras de alumínio. Estas foram submetidas a uma variação de temperatura, de $-30{ }^{\circ} \mathrm{C}$ até $250 \stackrel{\circ}{\circ}$ nas análises de lignina natural e lignina esterificada e de $-30^{\circ} \mathrm{C}$ até $190^{\circ} \mathrm{C}$ para as amostras de polímeros, com uma taxa de aquecimento de $10^{\circ} \mathrm{C} / \mathrm{min}$ e fluxo de nitrogênio de $30 \mathrm{~mL} / \mathrm{min} .^{60}$

\subsubsection{MICROSCOPIA ELETRÔNICA DE VARREDURA (MEV)}

A morfologia da lignina natural, lignina esterificada e dos polímeros formados foi determinada através de Microscopia Eletrônica de Varredura (MEV) em Microscópio modelo JSM-7001F (Jeol, Japão) operando em uma voltagem de aceleração de $15 \mathrm{keV}$. As amostras foram colocadas em stubs metalizadas com ouro. 


\subsubsection{5. - MICROSCOPIA ÓPTICA}

A morfologia da lignina natural, lignina esterificada e dos polímeros formados também foram analisados através de Microscopia Ótica em microscópio ótico trinocular da Carl Zeiss, modelo Axio Imager.A2 (Carl Zeiss Microscopy, EUA).

\subsubsection{ENSAIOS DE VISCOSIDADE}

A viscosidade dos materiais poliméricos ${ }^{61}$ obtidos foi analisada em Viscosímetro modelo HT-60 acoplado a Thermosel modelo 106 ambos marca Brookfield e spindle 34, onde aproximadamente $12 \mathrm{~g}$ do polímero foi colocado em porta amostra e introduzidos no thermosel (Figura 10). As amostras foram submetidas, durante 25 minutos, a temperaturas entre $180^{\circ} \mathrm{C}$ e $290^{\circ} \mathrm{C}$.

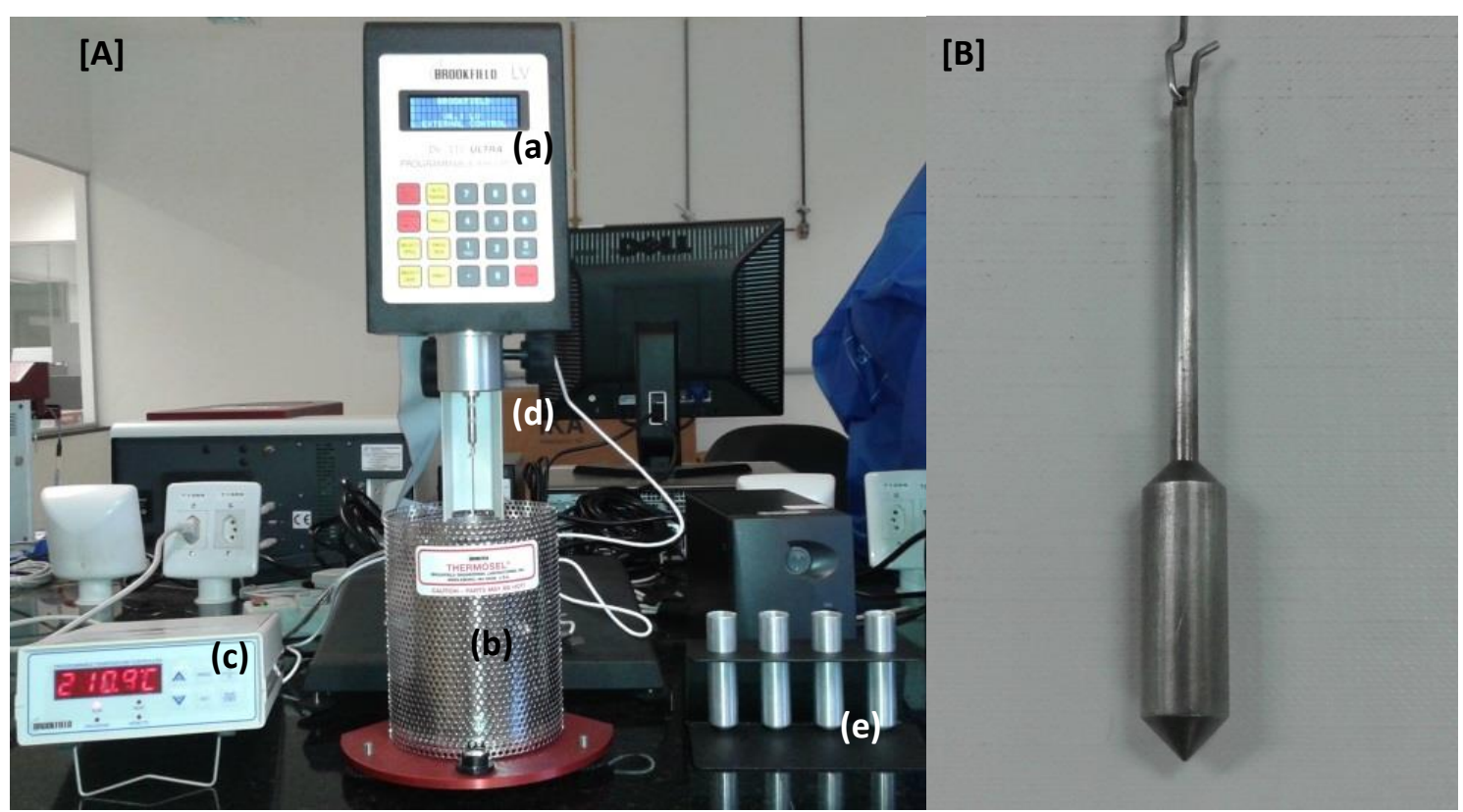

Figura 10: Sistema para ensaios de viscosidade: [A] (a) viscosímetro, (b) thermosel, (c) controle de temperatura, (d) suporte de alinhamento e (e) porta amostra; e [B] spindle 34. 
CAPÍTULO 4

RESULTADOS E DISCUSSÃO 


\subsection{DETERMINAÇÃO DO TEOR DE LIGNINA NA MADEIRA}

O teor de lignina presente na madeira de eucalipto foi determinado de acordo com método descrito por Gouveia, ${ }^{52}$ que consiste do tratamento com ácido sulfúrico e água. Após a calcinação da parte sólida residual o teor de lignina pôde ser determinado de acordo com a Equação 1.

O experimento foi realizado em triplicata e o teor de lignina presente na madeira de eucalipto utilizada nesse trabalho foi de aproximadamente $29 \%$ e está de acordo com o descrito na literatura, cujos valores são encontrados na faixa entre $25 \%$ e $30 \%$, ou seja, cada $10 \mathrm{~g}$ de madeira comportam cerca de $2,9 \mathrm{~g}$ de lignina. Os dados do experimento estão na Tabela 3.

$$
\% \text { Lig }=\left(M_{L s}-M_{C}\right) / M_{T}
$$

onde $: \%$ Lig = percentagem de lignina

$$
\begin{aligned}
& M_{L s}=\text { massa de lignina seca } \\
& M_{C}=\text { massa de cinzas } \\
& M_{T}=\text { massa total }
\end{aligned}
$$

Tabela 3: Dados obtidos na triplicata do experimento para determinação do teor de lignina na madeira de eucalipto.

\begin{tabular}{c|ccccc}
\hline \hline Experimento & $\mathbf{M}_{\mathbf{L s}}$ & $\mathbf{M}_{\mathbf{C}}$ & $\mathbf{M}_{\mathbf{T}}$ & \% Lig & \% Lig média \\
\hline 1 & 3,036 & 0,134 & 10,038 & 28,91 & \\
2 & 3,003 & 0,128 & 10,025 & 28,68 & $28,93 \pm 0,26$ \\
3 & 3,079 & 0,147 & 10,043 & 29,19 & \\
\hline
\end{tabular}

\subsection{EXTRAÇÃO E CARACTERIZAÇÃO DA LIGNINA NATURAL}

Foram utilizados dois métodos de extração de lignina com o objetivo de obter o melhor resultado. No processo Kraft modificado foi possível obter um rendimento de aproximadamente 50\%, ou seja, em $10 \mathrm{~g}$ de madeira foi possível extrair 1,4 g de lignina. Já o processo Kraft com pré-tratamento com acetona foi possível obter um rendimento de aproximadamente $25 \%$. Os rendimentos observados em ambos os experimentos podem ser atribuídos também a perdas durante o processo de filtragem e lavagem. 
$\mathrm{Na}$ caracterização por Espectroscopia no Infravermelho, as faixas de interesse de espectros de lignina natural são de $700 \mathrm{~cm}^{-1}$ a $4000 \mathrm{~cm}^{-1}$ que permitem identificar os grupos funcionais e as ligações típicas de lignina, como os estiramentos do anel siringila e guaiacila na faixa de $1325 \mathrm{~cm}^{-1}$ a $1330 \mathrm{~cm}^{-1}$ e 1270 $\mathrm{cm}^{-1}$ a $1275 \mathrm{~cm}^{-1}$, respectivamente. Outras faixas típicas de lignina natural estão entre 3200 e $3400 \mathrm{~cm}^{-1}$ característica da alta concentração de hidroxilas e cerca de $1100 \mathrm{~cm}^{-1}$, característica de álcoois secundários.

A caracterização de picos se faz de modo qualitativo, por comparação com dados tabelados. Os espectros apresentados têm função descritiva e de confirmação da presença de grupos característicos das ligninas, como mostra a Figura 11. $\mathrm{Na}$ Tabela 4, são mostrados os principais picos de absorção característicos no infravermelho para ligninas de madeira de eucalipto. Os valores obtidos neste trabalho são similares aqueles encontrados na literatura. ${ }^{22,56,57}$

Tabela 4: Bandas de absorção características da lignina.

\begin{tabular}{c|l}
\hline $\begin{array}{c}\text { Faixa de Absorção } \\
\left(\mathbf{c m}^{-1} \mathbf{)}\right.\end{array}$ & \multicolumn{1}{|c}{ Atribuição } \\
\hline $3400-3200$ & Estiramento O-H \\
$2940-2820$ & Estiramento $\mathrm{CH}$ de grupo metila e/ou metileno \\
$1740-1720$ & $\begin{array}{l}\text { Estiramento } \mathrm{C}=\mathrm{O} \text { em cetona não conjugadas e de } \\
\text { grupo éster }\end{array}$ \\
$1715-1710$ & Estiramento C=O não conjugado ao anel aromático \\
$1585-1580$ & Vibração do anel conjugado com um grupo a carbonila \\
$1515-1505$ & Vibração do anel aromático \\
$1470-1460$ & Deformações C-H assimétricas \\
$1430-1425$ & Vibração do anel aromático \\
$1420-1425$ & Ligaços C-H de grupos metil \\
$1370-1365$ & Deformações C-H simétricas \\
$1330-1325$ & Estiramento do anel siringila \\
$1270-1275$ & Estiramento do anel guaiacila \\
$1268-1270$ & Estiramento C-O aromático (metoxilas) \\
$1230-1215$ & Estiramento C-O aromático (fenil) \\
$1130-1120$ & Deformação (no plano) de C-H (em unidade siringila \\
$1100-1030$ & siringílico) \\
\hline
\end{tabular}




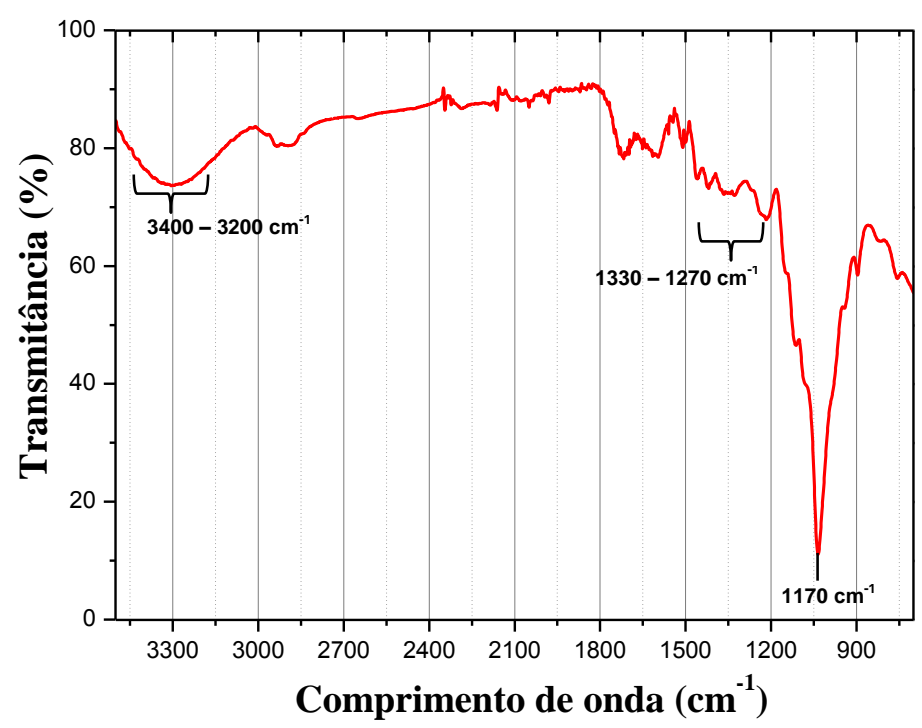

Figura 11: Espectro no IV da lignina natural da madeira de eucalipto.

A decomposição térmica da lignina natural resulta de complexas reações, caracterizadas por diferentes estágios de perdas de massa. Na curva TGA (Figura 12), a perda de massa em temperaturas entre $90-110{ }^{\circ} \mathrm{C}$ é devido, principalmente, à evaporação de água e substâncias de peso molecular baixo como monóxido e dióxido de carbono. A perda de massa em $200 \stackrel{\circ}{\mathrm{C}}$ refere-se ao início da reação de pirólise da lignina natural. $O$ processo de degradação da lignina natural ocorre geralmente acima de $300{ }^{\circ} \mathrm{C}^{62}$, onde são atribuídas as rupturas das ligações entre unidades resultando a perda de fenóis. Os anéis aromáticos, característicos da lignina natural, são degradados em temperaturas acima de $400{ }^{\circ} \mathrm{C}$. Os $20 \%$ de massa não degradada entre $550{ }^{\circ} \mathrm{C}$ e $800{ }^{\circ} \mathrm{C}$ é indicativo de possível formação coque.

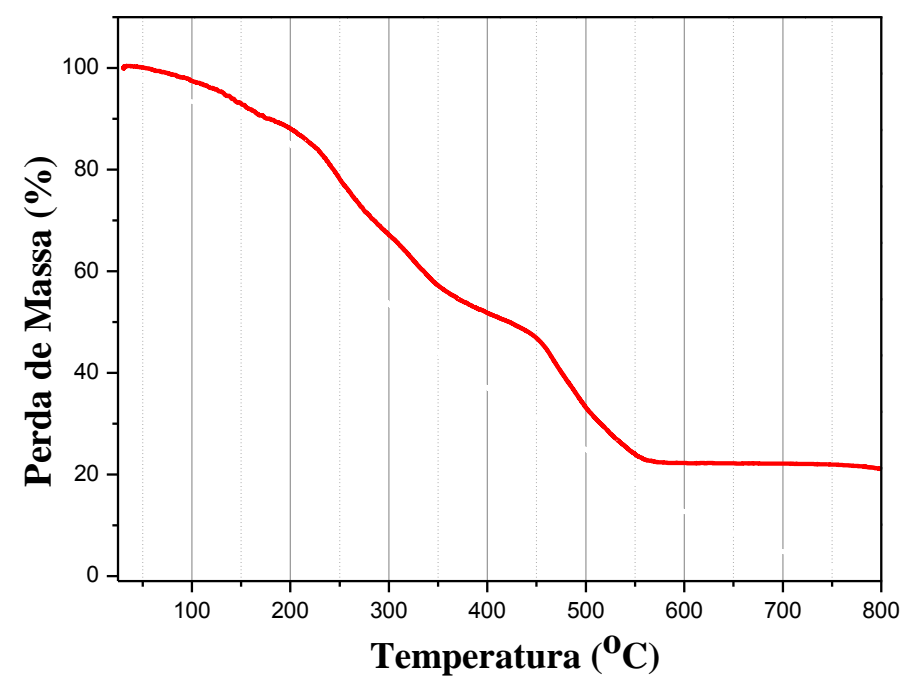

Figura 12: Estabilidade térmica da lignina natural de madeira de eucalipto. 
A lignina natural é um polímero amorfo, por isso sua transição vítrea $(\mathrm{Tg})$ varia dependendo da origem e do tipo de extração, geralmente está entre $85{ }^{\circ} \mathrm{C}$ e $120{ }^{\circ} \mathrm{C} .{ }^{63} \mathrm{~A}$ quantidade de água e o peso molecular da lignina natural também interferem na sua Tg. Na Figura 13 mostra que a transição vítrea da lignina natural estudada ocorre em $91,18^{\circ} \mathrm{C}$.

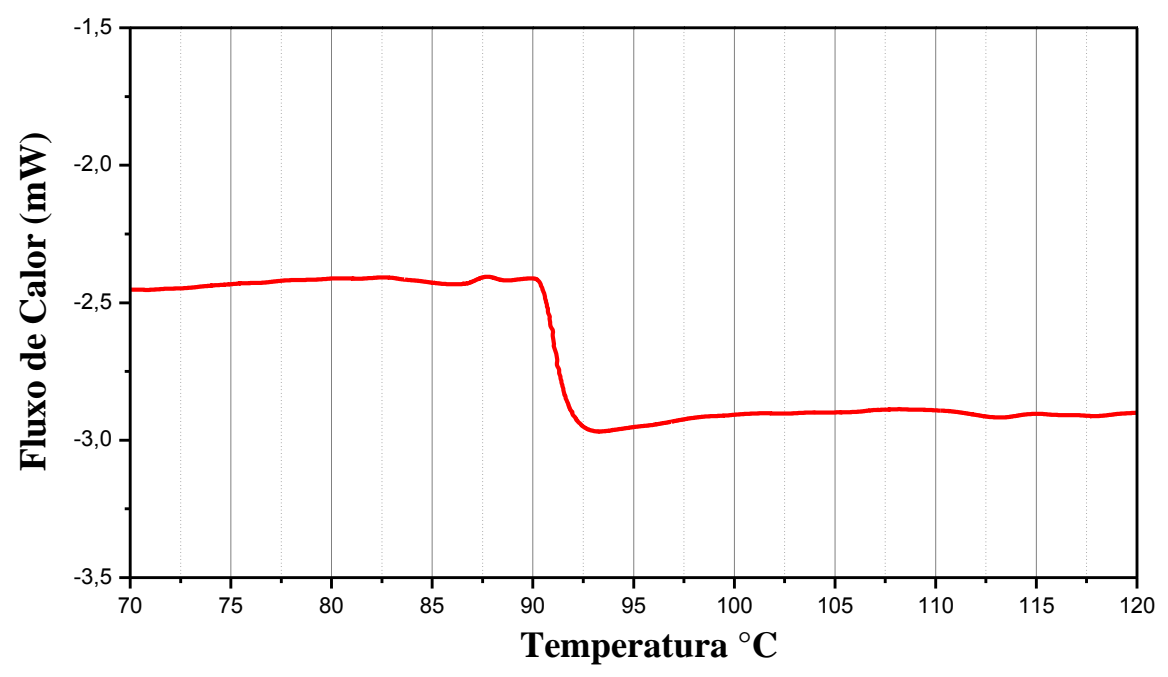

Figura 13: Termograma da lignina natural de madeira de eucalipto.

A lignina natural possui, assim como polímeros, alto peso molecular, o que dificulta a obtenção de bons sinais em ensaios de RMN. As bandas geralmente são largas com possíveis hidrogênios blindados por grupos químicos. A análise de RMN da lignina natural teve como objetivo a avaliação das diferentes ligações de prótons de hidrogênio presentes na lignina natural, como os ligados a cadeias alifáticas, núcleos aromáticos e hidrogênios metoxílicos, alifáticos e fenólicos. ${ }^{22,3}$

$\mathrm{O}$ espectro de RMN ${ }^{1} \mathrm{H}$ fornece informações importantes sobre os grupos hidroxilas da molécula de lignina natural. Os principais sinais são: 2,02 ppm (prótons de acetato alifático) de hidroxilas alifáticas, 2,16 ppm e 2,29 ppm (prótons de acetato aromáticos) de hidroxilas fenólicas e 3,82 ppm relativo a átomos de hidrogênio metoxílicos. Na Figura 14 é possível observar o espectro de $\mathrm{RMN}{ }^{1} \mathrm{H}$ da lignina natual. A Tabela 5 apresenta as atribuições dos sinais de hidrogênio do espectro de RMN ${ }^{1} \mathrm{H}$. 


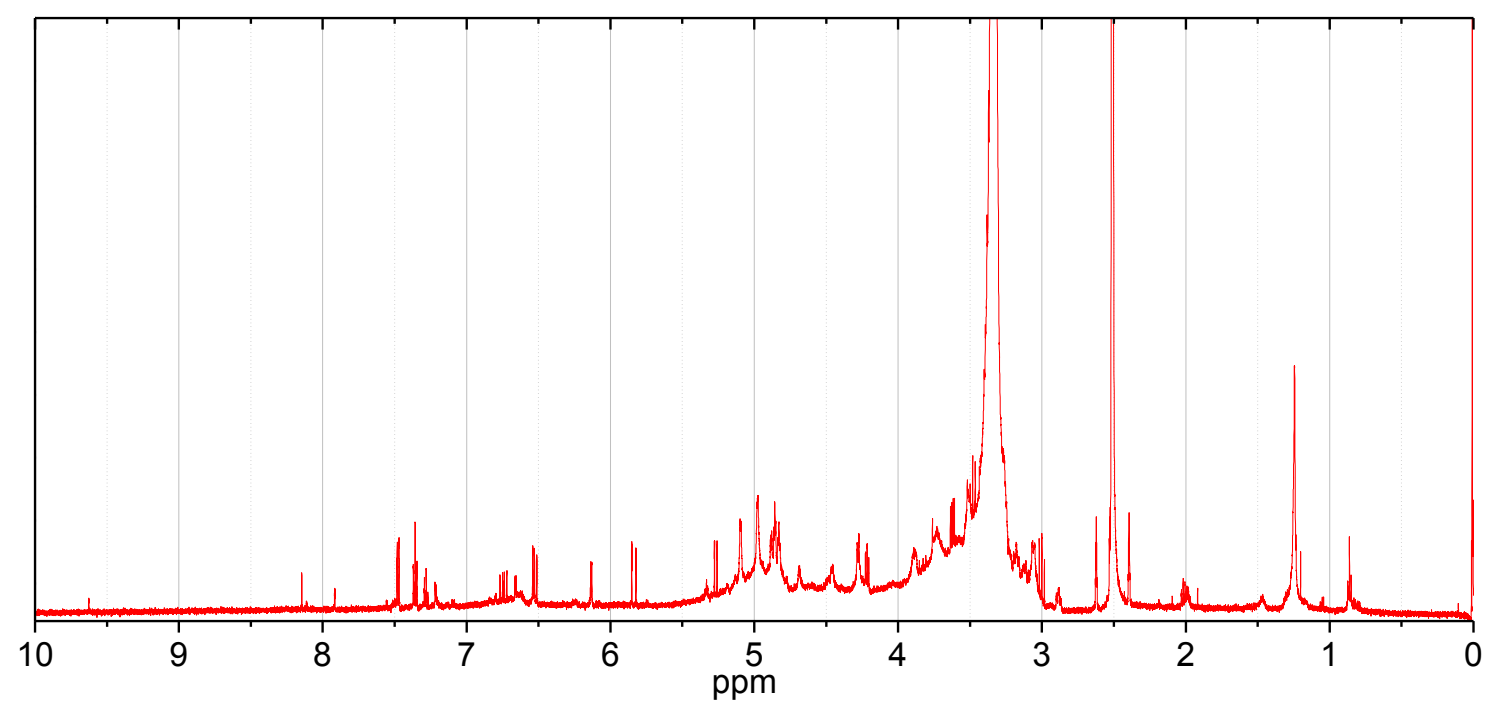

Figura 14: Espectro de $\mathrm{RMN}{ }^{1} \mathrm{H}$ da lignina natural de madeira de eucalipto.

Tabela 5: Atribuições dos principais sinais de hidrogênio do espectro de $\mathrm{RMN}{ }^{1} \mathrm{H}$ da lignina natural. ${ }^{3}$ ppm

\section{Atribuição}

\begin{tabular}{l|l|}
\hline $2,00-2,02$ & $\left(\mathrm{CH}_{3^{-}}\right)$prótons de acetatos alifáticos \\
$2,16-2,29$ & $\left(\mathrm{CH}_{3^{-}}\right)$prótons de hidrocarbonetos fenólicos \\
$2,59-2,61$ & $(\mathrm{H}-)$ de estruturas $\beta-\beta$ \\
$3,82-3,87$ & $\left(\mathrm{CH}_{3} \mathrm{O}-\right)$ prótons em grupos metoxílicos \\
$4,23-4,26$ & $(\mathrm{H}-)$ y em várias estruturas \\
\hline
\end{tabular}

As amostras de lignina natural na forma particulada apresentam tamanho médio na faixa entre $25 \mu \mathrm{m}$ e $150 \mu \mathrm{m}$, como observado nas imagens de microscopia eletrônica de varredura (MEV) (Figura 16) e microscopia ótica (Figura 15).
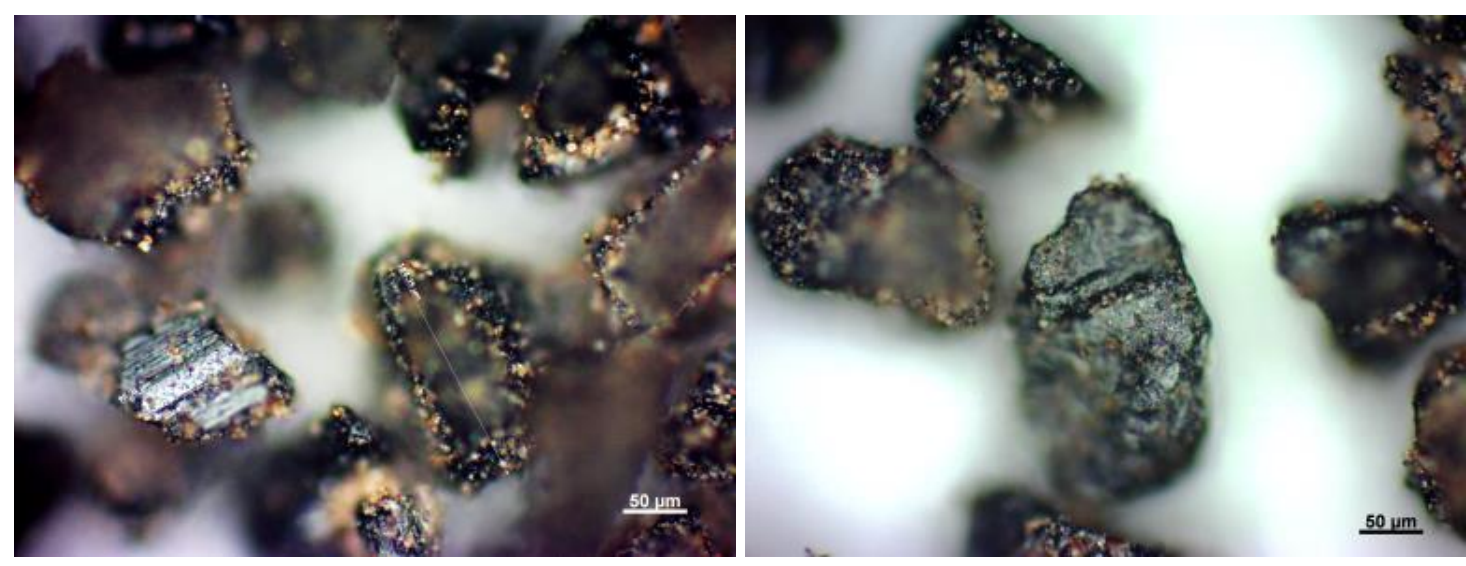

Figura 15: Imagens de microscopia ótica da lignina natural, com escalas de $50 \mu \mathrm{m}$. 


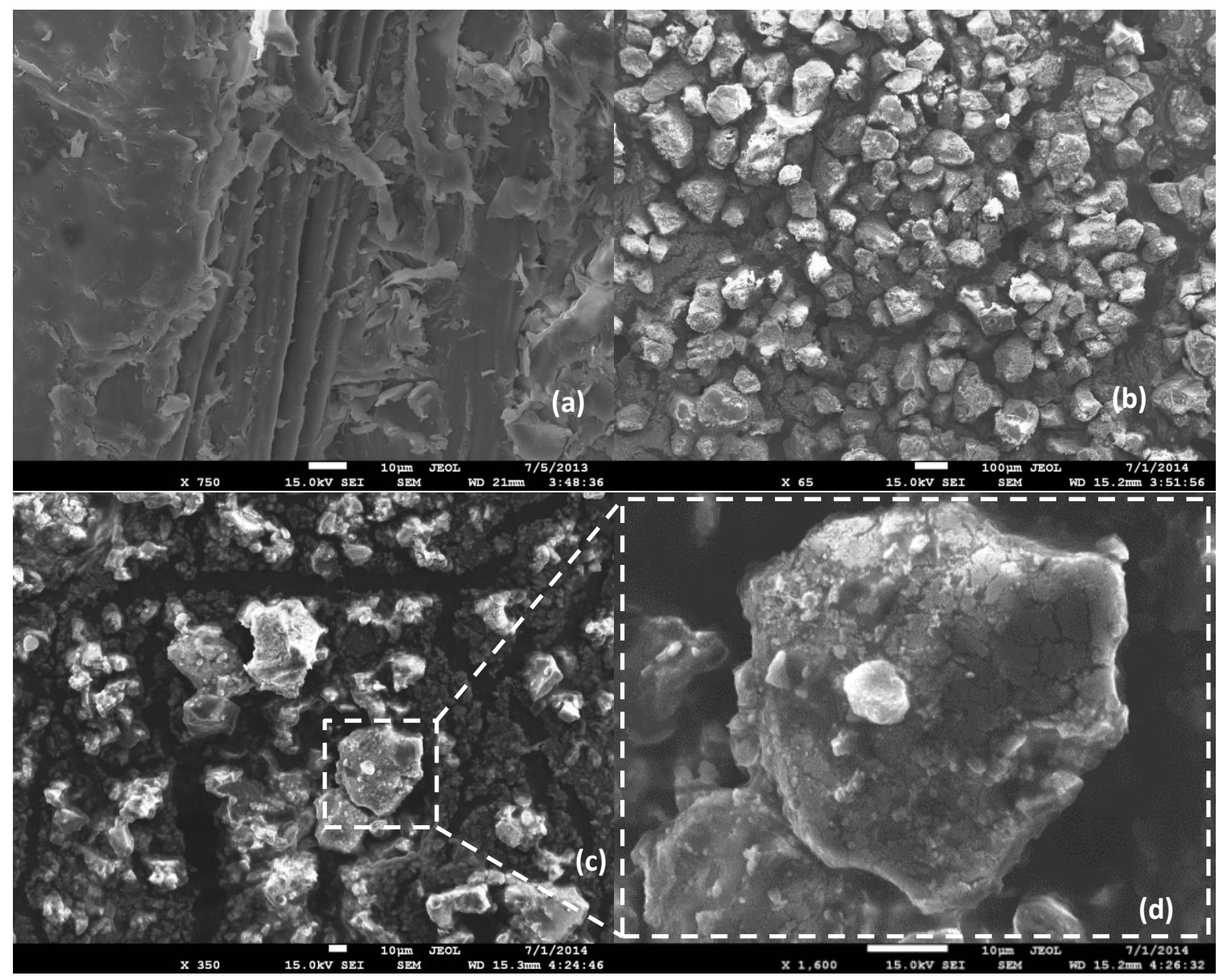

Figura 16: Micrografias de MEV, onde: (a) madeira moída, (b) amostra de lignina natural com tamanhos entre 100-150 $\mu \mathrm{m}$ e com aproximação de 65 vezes, (c) lignina natural com tamanhos entre 25-100 $\mu \mathrm{m}$ e aproximação de 350 vezes e (d) lignina natural com aproximação de 1600 vezes da área em destaque da micrografia (c).

\subsection{ESTERIFICAÇÃO DA LIGNINA E SUA CARACTERIZAÇÃO}

$\mathrm{O}$ processo de esterificação teve como alvo os grupos hidroxilas $(\mathrm{OH})$ presentes na lignina natural, visando a substituição das hidroxilas por duplas ligações para aumentar a reatividade na polimerização radicalar. Como um importante efeito secundário, neste trabalho, a esterificação da lignina com anidrido metacrílico permite aumentar a sua solubilidade em estireno. ${ }^{35}$

$O$ teor de hidroxilas na lignina natural foi determinado em uma etapa previa do processo de esterificação e foi de aproximadamente $5,7 \%$, com base na Equação 2. Esse processo foi necessário para estabelecer uma proporção ótima entre os reagentes, de tal forma que, as reações de esterificação foram conduzidas utilizando-se cerca de $6 \mathrm{~mL}$ de anidrido metacrílico para cada grama de lignina. Os resultados obtidos das reações em triplicata estão organizados 
na Tabela 6. No processo de esterificação da lignina usando anidrido metacrílico foi possível recuperar aproximadamente 64 \% a massa de lignina.

$$
\% \mathrm{OH}=\left(\mathrm{Abs}_{250 \mathrm{~nm}} \times 0,192\right) / \mathrm{C}_{\text {lig }}
$$

onde : \% OH = percentagem de $\mathrm{OH}$

$\mathrm{Abs}_{250 \mathrm{~nm}}=$ absorbância na região de $250 \mathrm{~nm}$

A constante 0,192 equivale a absorbância relacionada ao grupo $\mathrm{OH}$ em $250 \mathrm{~nm}$ em L.g ${ }^{-1} \cdot \mathrm{cm}^{-1}$

$\mathrm{C}_{\text {lig }}=$ concentração da solução de lignina natural em $\mathrm{g} / \mathrm{L}$

Tabela 6: Dados obtidos na triplicata para determinação de hidroxilas na lignina natural.

\begin{tabular}{c|cccc}
\hline \hline Experimento & Abs $250 \mathrm{~nm}$ & $\mathbf{C}_{\text {lig }}$ & $\% \mathbf{O H}$ & Média (\% OH) \\
\hline 1 & 2,969 & 0,1 & 5,70 & \\
2 & 2,970 & 0,1 & 5,70 & $5,70 \pm 0,006$ \\
3 & 2,968 & 0,1 & 5,69 & \\
\hline
\end{tabular}

Após o processo de esterificação, o experimento foi repetido com o objetivo de determinar a teor de hidroxilas ainda presentes na lignina esterificada e o teor de substituição. Os resultados obtidos em triplicata estão organizados na Tabela 7, onde foi possível determinar que na lignina esterificada havia aproximadamente $1,55 \%$ de hidroxilas. O teor de substituição, determinado pela Equação 3, foi de 72,8 \%. Esse teor de substituição pode ser explicado devido ao impedimento estéreo que ocorre na estrutura da lignina.

Tabela 7: Dados obtidos na triplicata para determinação de hidroxilas na lignina esterificada.

\begin{tabular}{c|cccc}
\hline \hline Experimento & Abs $_{250 \mathrm{~nm}}$ & $\mathbf{C}_{\text {lig/ester }}$ & $\% \mathbf{O H}$ & Média (\% OH) \\
\hline 1 & 0,799 & 0,1 & 1,53 & \\
2 & 0,818 & 0,1 & 1,57 & $1,55 \pm 0,021$ \\
3 & 0,802 & 0,1 & 1,54 & \\
\hline
\end{tabular}


onde : \% Subst = teor de substituição

$\% \mathrm{OH}_{\text {lig/nat }}=$ percentagem de $\mathrm{OH}$ na lignina natural

$\% \mathrm{OH}_{\text {lig/est }}=$ percentagem de $\mathrm{OH}$ na lignina esterificada

Na caracterização por IV (Figura 17) é possível observar, em comparação com a lignina natural, a diminuição da banda característica de hidroxilas (3200 $3400 \mathrm{~cm}^{-1}$ ) e um aumento na banda característica de ésteres $\left(1720-1740 \mathrm{~cm}^{-1}\right)$. Esse método é uma comprovação qualitativa da esterificação da lignina.

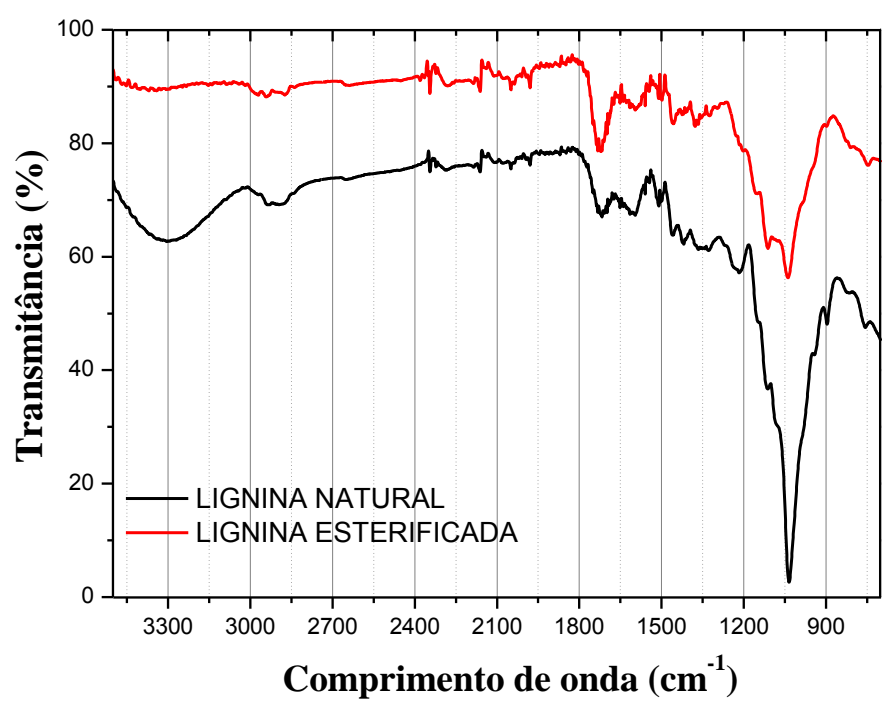

Figura 17: Espectros no IV da lignina natural e esterificada.

$\mathrm{Na}$ decomposição térmica da lignina esterificada, descrita pela curva de TGA (Figura 18), foram observadas diferenças significativas, em comparação a lignina natural, mostrando que a reação de esterificação levou a uma diminuição da estabilidade térmica com temperaturas de decomposição: entre $200{ }^{\circ} \mathrm{C}$ e $300^{\circ} \mathrm{C}$ com degradação de aproximadamente $50 \%$, contra apenas $42 \%$ da lignina natural; entre $300^{\circ} \mathrm{C}$ e $550 \stackrel{\circ}{\circ}$ com degradação de aproximadamente $80 \%$, contra $75 \%$ da lignina natural; e temperatura acima de $550 \stackrel{\circ}{\circ}$ ocorre a degradação de $98 \%$ da lignina esterificada e na curva da lignina natural mostrou a formação de coque. 


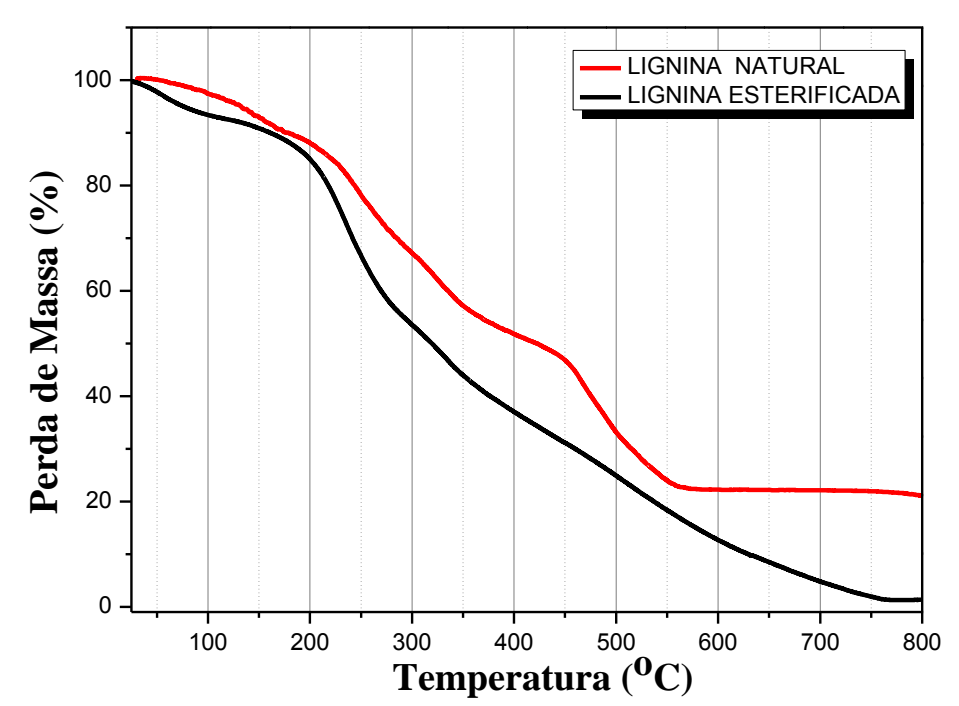

Figura 18: Estabilidade térmica da lignina natural e esterificada.

A transição vítrea da lignina esterificada, em comparação com lignina natural, teve um aumento, isso devido a substituição dos grupos $\mathrm{OH}$ por grupos maiores, causando a redução da capacidade de mobilidade das cadeias da lignina. A Figura 19 mostra que a transição vítrea da lignina esterificada ocorre em $97,9 \stackrel{\circ}{\circ} \mathrm{C}$.

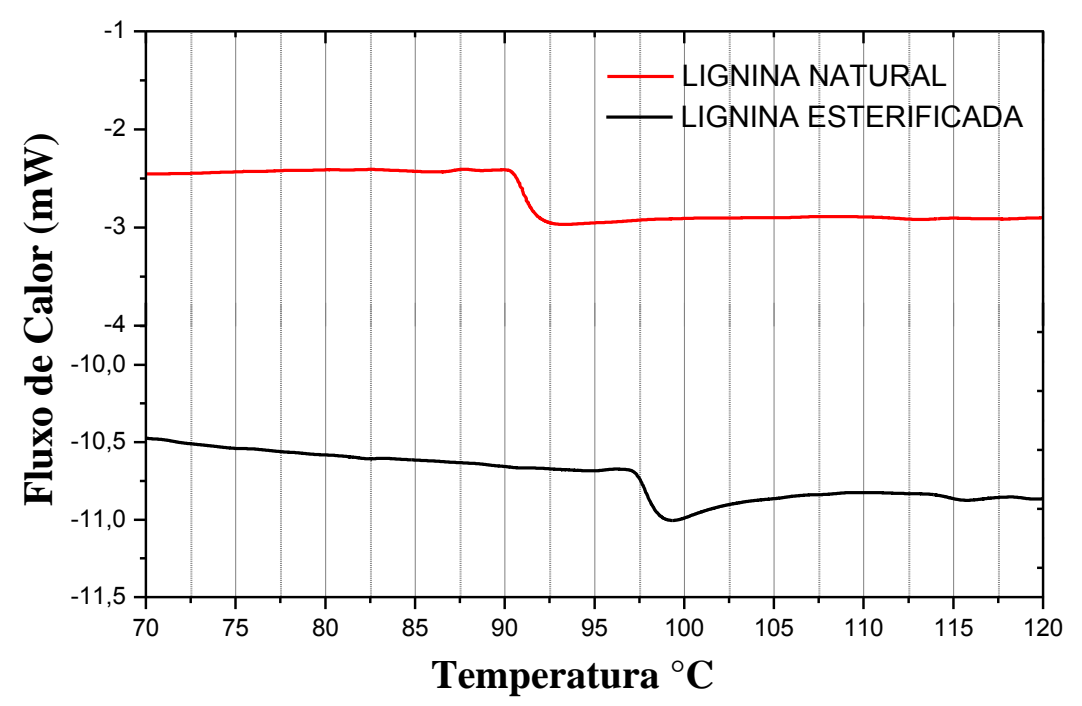

Figura 19: Termograma da lignina natural e esterificada.

A análise de RMN da lignina esterificada teve como objetivo a investigar das diferentes ligações de prótons de hidrogênio presentes na lignina esterificada em comparação a lignina não natural. As principais faixas de interesse após esterificação da lignina são: $\left(-\mathrm{CH}_{3}\right)$ 1,7 - 2,05 ppm e $\left(=\mathrm{CH}_{2}\right)$ 5,4 ppm - 6,2 ppm, que caracterizam o anidrido metacrílico, as quais podem ser observadas na Figura 20. 


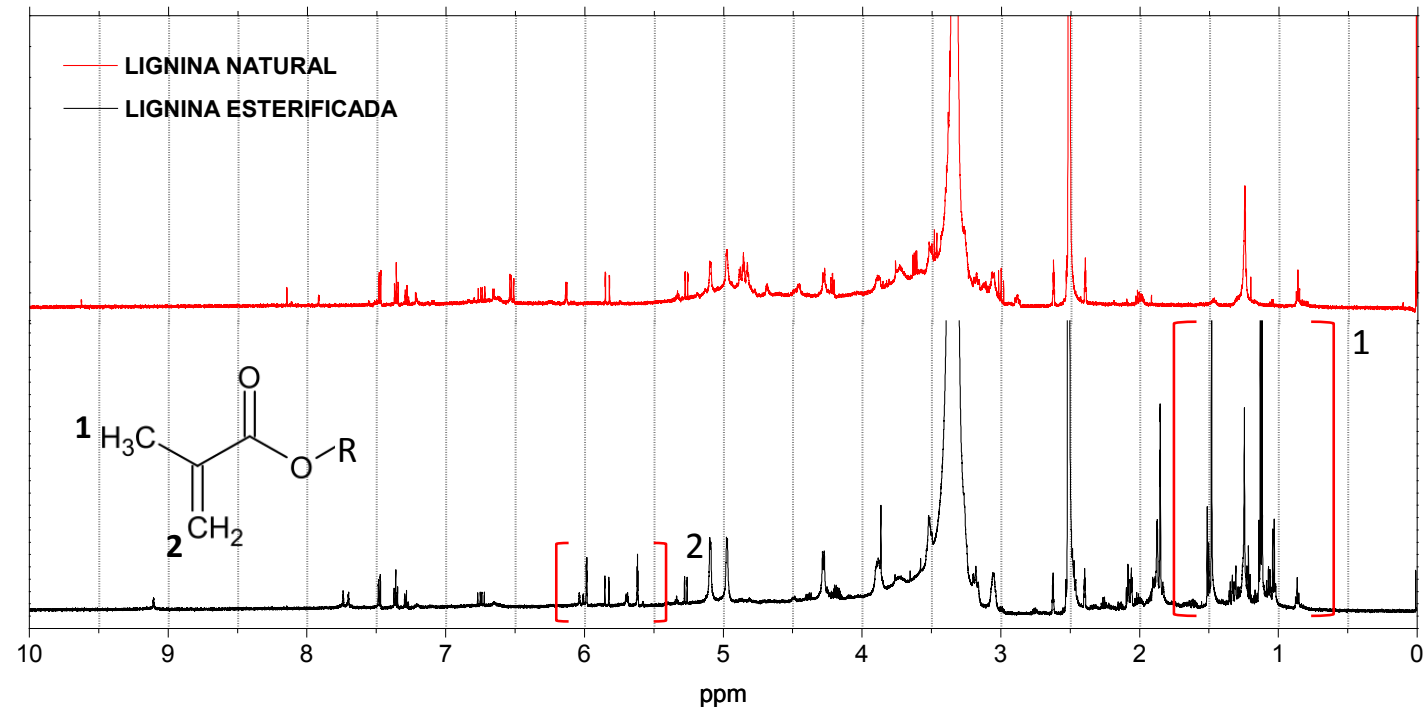

Figura 20: Espectro de $\mathrm{RMN}{ }^{1} \mathrm{H}$ da lignina natural e esterificada.

A microscopia eletrônica de varredura (MEV) (Figura 21) também teve por objetivo a observação de sua morfologia, pela qual foi possível observar que, após esterificação, houve o aparecimento de partículas menores que $10 \mu \mathrm{m}$.

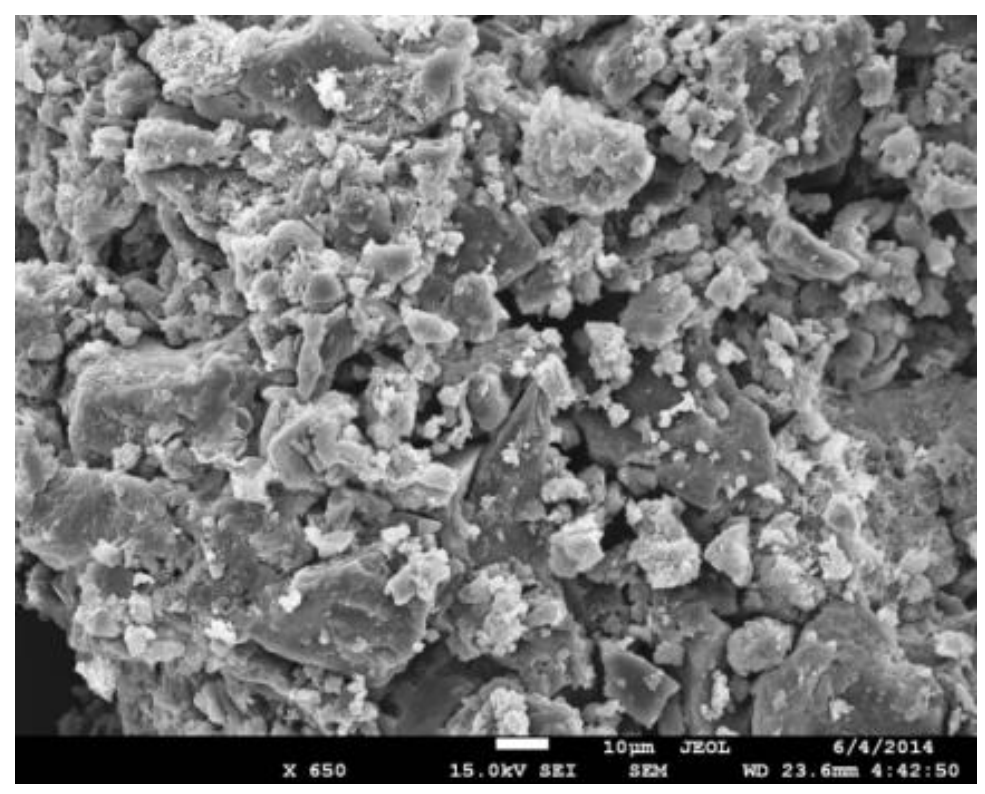

Figura 21: Micrografias de MEV da lignina esterificada.

Concluída a esterificação, foi realizado um teste de solubilidade onde verificou-se um aumento da solubilidade da lignina esterificada em relação a lignina natural. A solubilidade da lignina natural em estireno é de aproximadamente $8 \%$, já a lignina esterificada é de cerca de $38 \%$. Um aumento da solubilidade leva a formação de partículas poliméricas mais homogêneas e também uma melhor 
incorporação da lignina aumentando a conversão da reação de polimerização. Embora haja um aumento da solubilidade, ainda está abaixo do descrito na literatura

que é de $55 \%{ }^{27}$ É importante também ressaltar que o anidrido metacrílico foi utilizado estrategicamente para conferir a lignina esterificada a capacidade de se combinar quimicamente com o estireno via reação de copolimerização.

\subsection{POLIMERIZAÇÃO EM MASSA-SUSPENSÃO COM ESTIRENO E LIGNINA NATURAL}

Os compósitos poliméricos foram formados a partir de lignina com tamanho médio de $75 \mu \mathrm{m}$ - $100 \mu \mathrm{m}$ e estireno. A Figura 22 mostra a curva de conversão do estireno no processo de polimerização em massa, na qual foi possível saber qual o tempo para a adição de PVA. Esse tempo é escolhido devido a observação do aumento da viscosidade do meio reacional, e como a conversão deve ser entre $30 \%$ e $60 \%$, o tempo de 120 minutos foi escolhido porque a conversão é em torno de 57 \%. É importante ressaltar que a adição de PVA num meio reacional com conversão abaixo de $30 \%$, não haveria uma boa incorporação da lignina na matriz polimérica e numa conversão acima de 60 \% haveria aglomeração na fase orgânica devido a elevada viscosidade do meio reacional. Nesse caso, a solução de PVA é acrescentada no sistema reacional, sob forte cisalhamento, quando a conversão de reação é em torno de $57 \%$, que corresponde a um tempo de reação de 120 minutos. Esse processo foi escolhido com o objetivo de aumentar a incorporação da lignina na matriz polimérica e facilitar a manipulação do polímero produzido.

Desse ponto em diante a reação assume um comportamento típico de polimerização em suspensão. Nesse processo a primeira etapa é a mais importante, pois, como há uma baixa compatibilidade da lignina no estireno, a primeira etapa proporciona um melhor contato entre as espécies reativas aumentando a incorporação da lignina na matriz polimérica de poliestireno, e minimiza a solubilidade da lignina na fase aquosa depois do acréscimo da solução de PVA, uma vez que a lignina é mais solúvel na fase aquosa que na fase orgânica. A Tabela 8 apresenta as condições experimentais de todas as reações com $5 \%, 10 \%$ e $20 \%$ de lignina e suas respectivas conversões. 


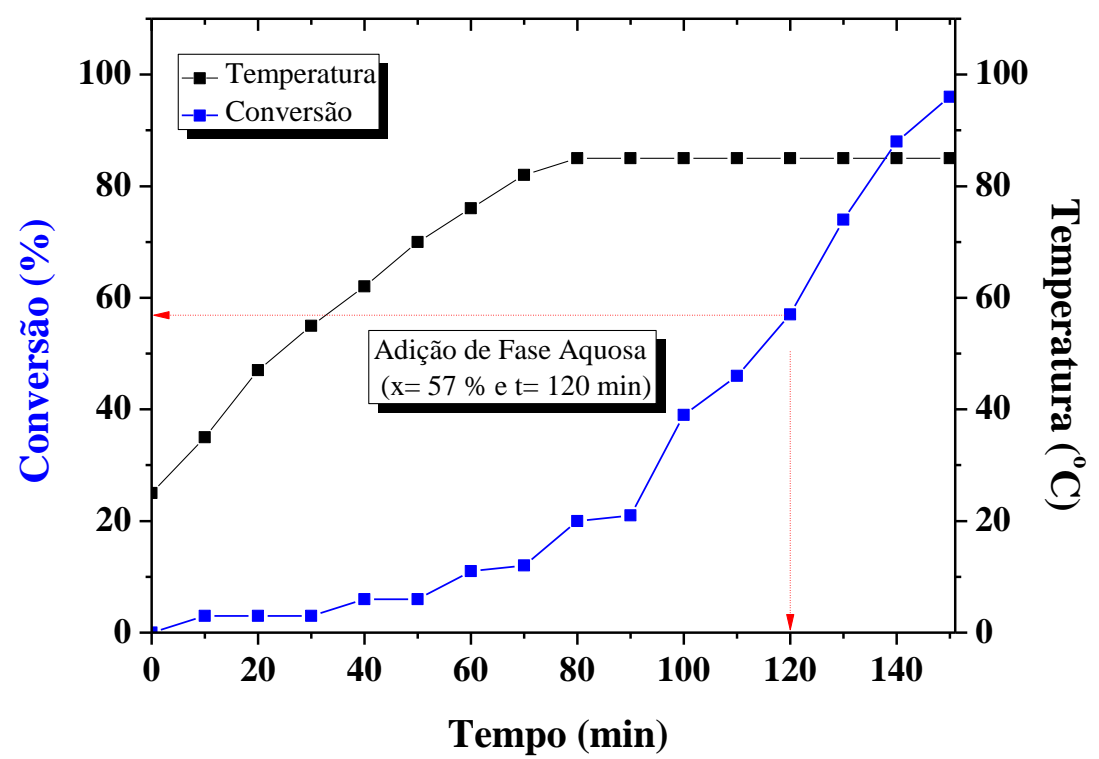

Figura 22: Curva de conversão da polimerização em massa de estireno.

Tabela 8: Condições experimentais dos processos de polimerização em massa-suspensão usando lignina natural.

\begin{tabular}{c|cccccc}
\hline \hline Amostras & $\begin{array}{c}\text { Lignina } \\
(\%)\end{array}$ & $\begin{array}{c}\text { Estireno } \\
(\mathbf{g})\end{array}$ & $\begin{array}{c}\text { Lignina } \\
(\mathbf{g})\end{array}$ & PVA (mL) & BPO (g) & $\begin{array}{c}\text { Conversão } \\
(\%)\end{array}$ \\
\hline 1 & 5 & 58,196 & 2,102 & $135(5 \mathrm{~g} / \mathrm{L})$ & 2,078 & 93,1 \\
2 & 5 & 58,131 & 2,956 & $135(5 \mathrm{~g} / \mathrm{L})$ & 2,057 & 96,1 \\
3 & 5 & 58,315 & 2,941 & $135(5 \mathrm{~g} / \mathrm{L})$ & 2,042 & 97,3 \\
4 & 5 & 58,125 & 2,923 & $135(5 \mathrm{~g} / \mathrm{L})$ & 2,047 & 97,7 \\
5 & 10 & 58,098 & 5,834 & $135(5 \mathrm{~g} / \mathrm{L})$ & 2,051 & 78,3 \\
6 & 10 & 58,245 & 5,910 & $135(5 \mathrm{~g} / \mathrm{L})$ & 4,069 & 84,3 \\
7 & 10 & 58,035 & 5,866 & $135(7 \mathrm{~g} / \mathrm{L})$ & 4,067 & 97,8 \\
8 & 20 & 58,078 & 11,697 & $135(10 \mathrm{~g} / \mathrm{L})$ & 9,046 & 98,8 \\
\hline
\end{tabular}

As reações foram realizadas sob uma agitação constante de 750 rpm tanto na primeira etapa (massa) quanto na segunda (suspensão), contudo houve uma baixa incorporação de lignina no polímero, o que pôde ser observado na Figura 23 e uma conversão de 93,1 \% (Amostra 1), o que pode ser considerada baixa. O polímero formado tem entre $60 \mu \mathrm{m}$ e $120 \mu \mathrm{m}$ e a distribuição do tamanho de partícula está representado na Figura 24, apresentando um tamanho médio equivalente a $89 \mu \mathrm{m}$. 


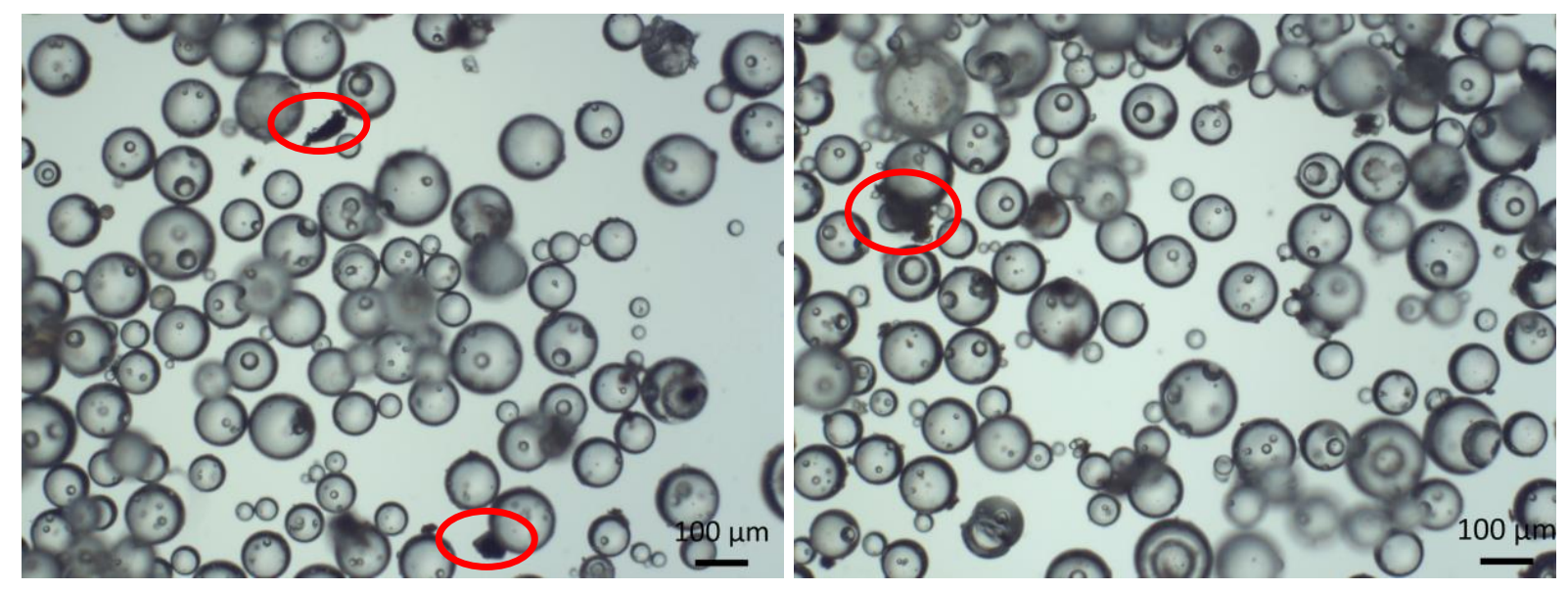

Figura 23: Imagens de microscopia ótica da amostra 1 dos polímeros obtidos a partir de $5 \%$ de lignina natural e conversão de $93,1 \%$, em destaque as regiões com lignina livre.

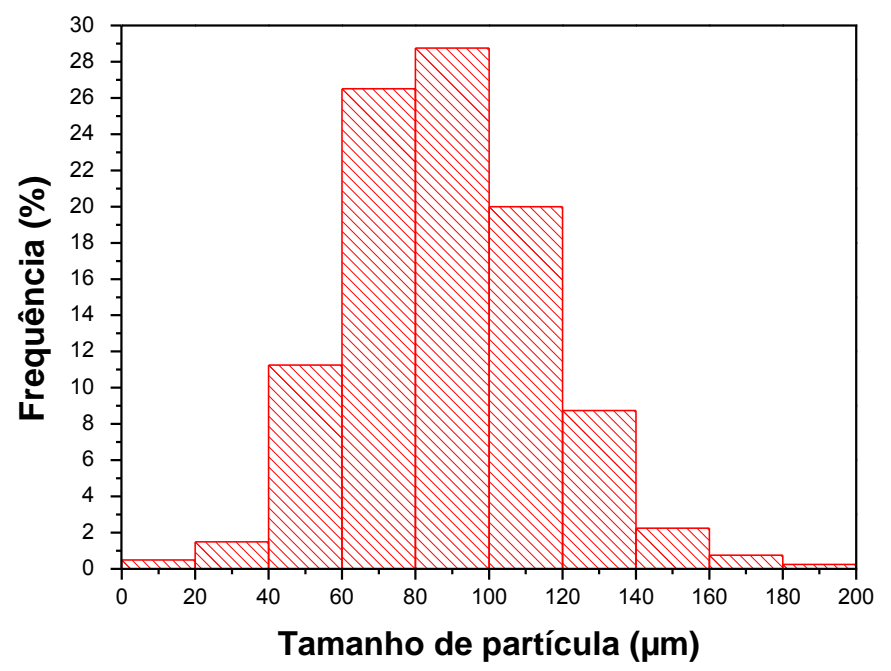

Figura 24: Distribuição do tamanho de partícula da amostra 1 dos polímeros obtidos a partir de $5 \%$ de lignina natural e conversão de $93,1 \%$.

Como base nos resultados preliminares, que evidenciaram a segregação parcial da lignina, a primeira etapa passou a ser mantida sob agitação de 1.000 rpm, com o objetivo de melhorar a distribuição da lignina natural, que possui compatibilidade reduzida com o estireno e aumentar o tamanho da partícula; e a segunda etapa permaneceu sob agitação de $750 \mathrm{rpm}$. Com isso houve um aumento na conversão, passando para 96,1\% (Amostra 2). Contudo as imagens ainda mostravam uma baixa incorporação de lignina no polímero e um acúmulo na sua superfície (Figuras 25 e 26), embora houvesse um aumento do tamanho de partícula (entre $180 \mu \mathrm{m}$ e $240 \mu \mathrm{m}$, com tamanho médio de partícula igual a $193 \mu \mathrm{m}$ ) como mostra a Figura 27. A despeito disto, vale considerar que a parcela de lignina livre 
(segregada da fase termoplástica de poliestireno) pode ser considerada baixa. Além disto, como ilustrado nas Figuras 24 e 25, o compósito polimérico a base de estireno/lignina foi formado do tamanho característico e similar ao da lignina adicionada ao processo, o que significa que uma parcela elevada da lignina encontra-se distribuída na matriz de poliestireno.

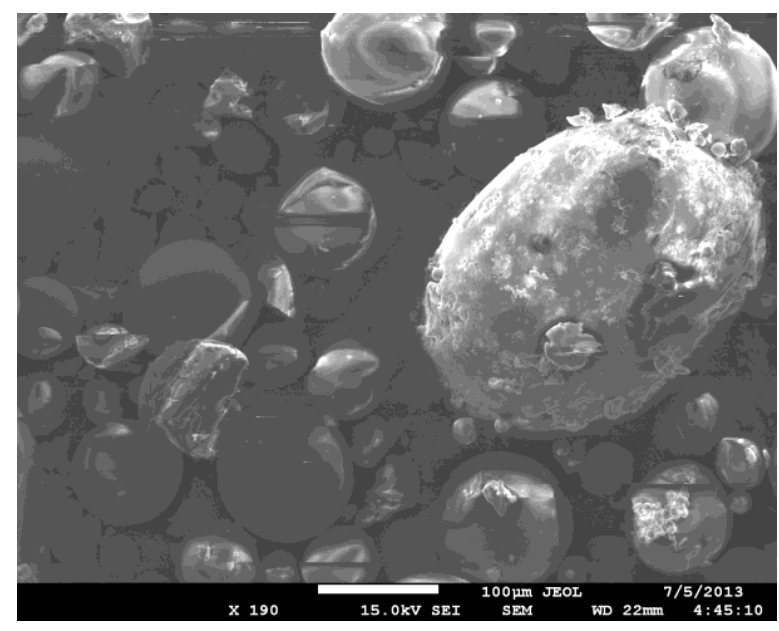

Figura 25: Micrografia de MEV da amostra 2 dos polímeros obtidos a partir de $5 \%$ de lignina natural e conversão de $96,1 \%$.

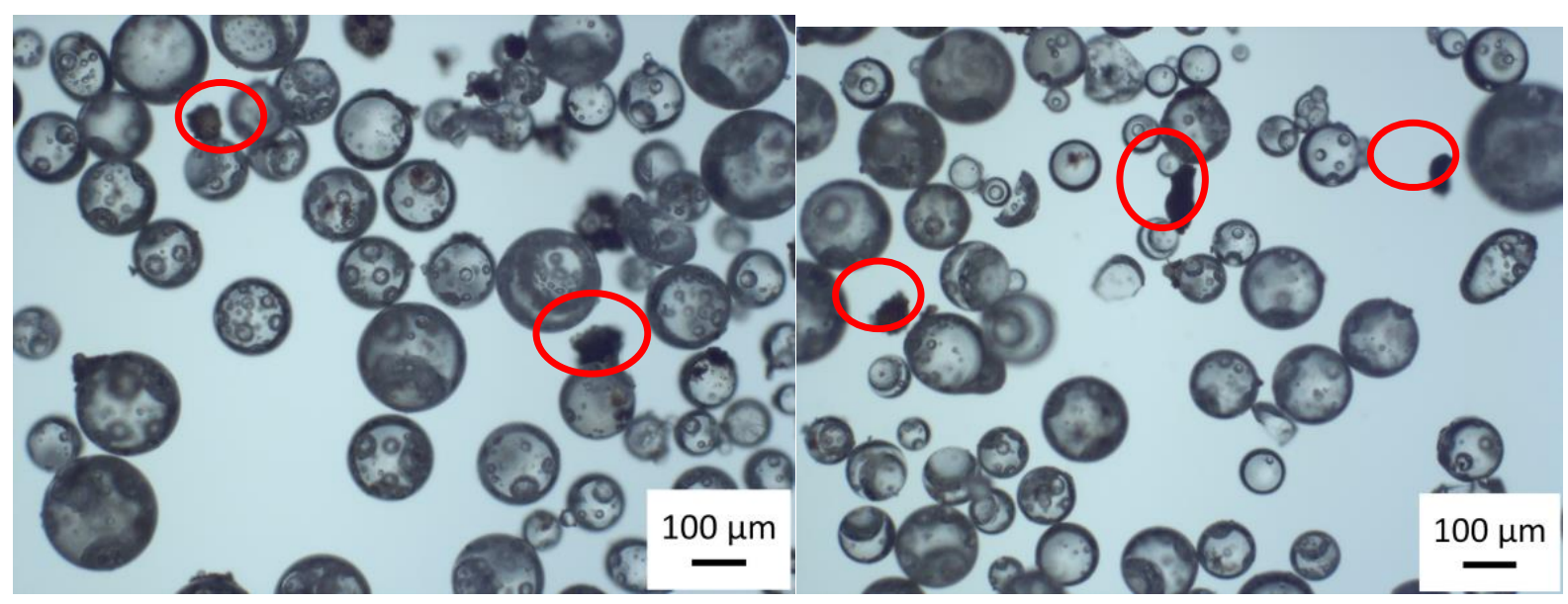

Figura 26: Imagens de microscopia ótica da amostra 2 dos polímeros obtidos a partir de $5 \%$ de lignina natural e conversão de 96,1\%, em destaque as regiões com lignina livre. 


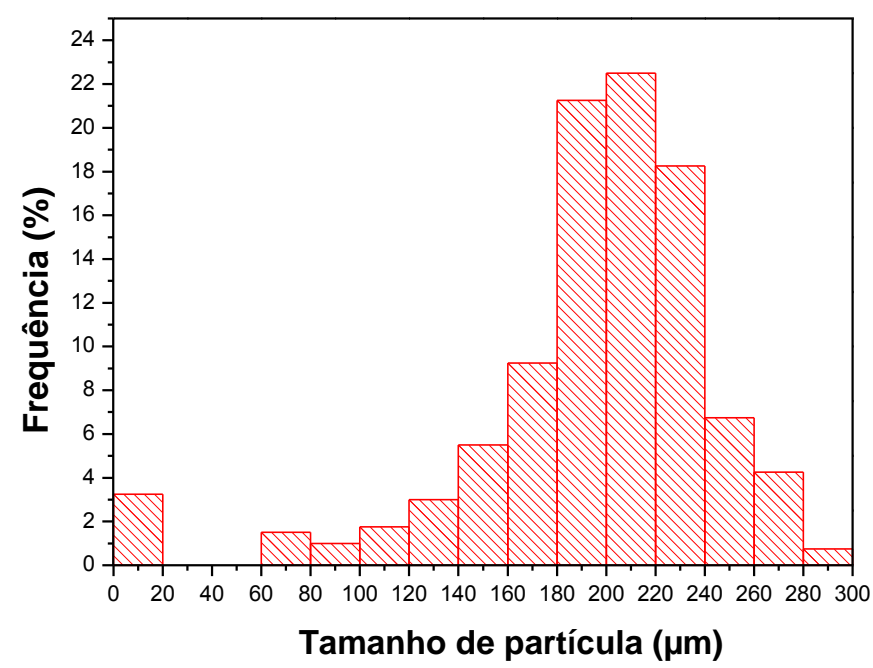

Figura 27: Distribuição de partícula da amostra 2 dos polímeros obtidos a partir de $5 \%$ de lignina natural e conversão de $96,1 \%$.

Após essas duas reações, a primeira etapa continuou sob agitação de $1.000 \mathrm{rpm}$, e a segunda etapa $500 \mathrm{rpm}$, para aumentar o tamanho da partícula de polímero e a incorporação de lignina. Esse experimento teve um aumento da conversão, passando para 97,3\% (Amostra 3). As imagens mostraram uma melhor incorporação de lignina no polímero (Figura 28). Na Figura 29 é possível observar um aumento do tamanho de partícula, entre $220 \mu \mathrm{m}$ e $280 \mu \mathrm{m}$, cujo tamanho médio de partículas é igual a $224 \mu \mathrm{m}$. Para as análises de viscosidade, foi realizada uma nova reação com os mesmos parâmetros da Amostra 3, com uma conversão de 97,7 $\%$ (Amostra 4).

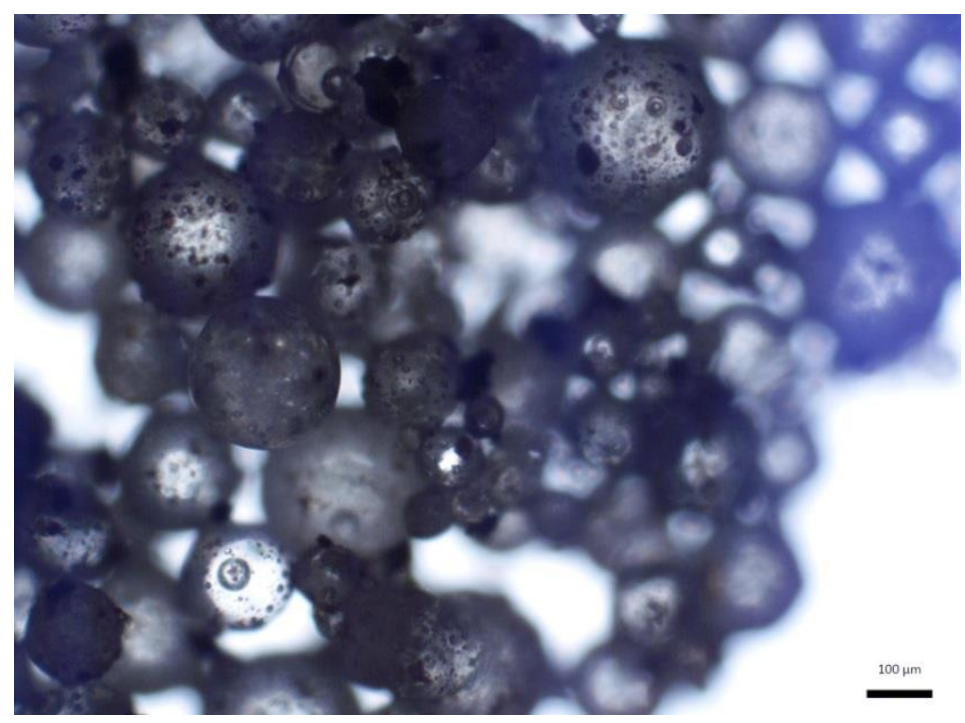

Figura 28: Imagens de microscopia ótica da amostra 3 dos polímeros obtidos a partir de $5 \%$ de lignina natural e conversão de $97,3 \%$. 


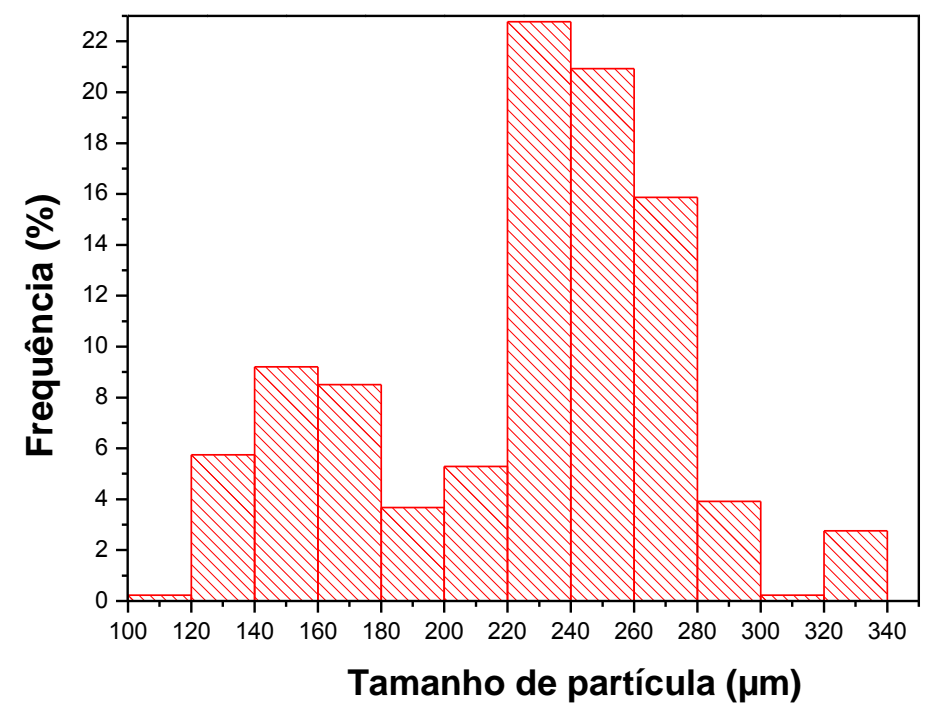

Figura 29: Distribuição de partícula ótica da amostra 3 dos polímeros obtidos a partir de $5 \%$ de lignina natural e conversão de 97,3\%.

A Figura 30 mostra a morfologia da amostra 3, onde foi possível observar uma estrutura morfológica com macrocavidades, esférica e regular. As macrocavidades são formadas devido ao acúmulo de microgotas de água dentro das partículas de polímeros, que desaparecem no decorrer da reação e durante o processo de secagem, deixando vazios os espaços antes preenchidos por água.

A partícula quebrada apresentada na imagem foi cortada por microtomia. A aproximação da área em destaque possibilitou a visualização de partículas de lignina dentro do polímero, isso pode indicar que o crescimento da cadeia polimérica ocorre inicialmente dentro da partícula de lignina, e com $o$ aumento da cadeia há quebra da estrutura da lignina ocasionado um polímero com fragmentos menores de lignina. $\mathrm{Na}$ Figura 31 podemos notar que a lignina foi incorporada ao polímero, tal fato é evidenciado pela diferença de coloração observada na partícula, onde as partes mais escuras são lignina e as mais claras são poliestireno. 


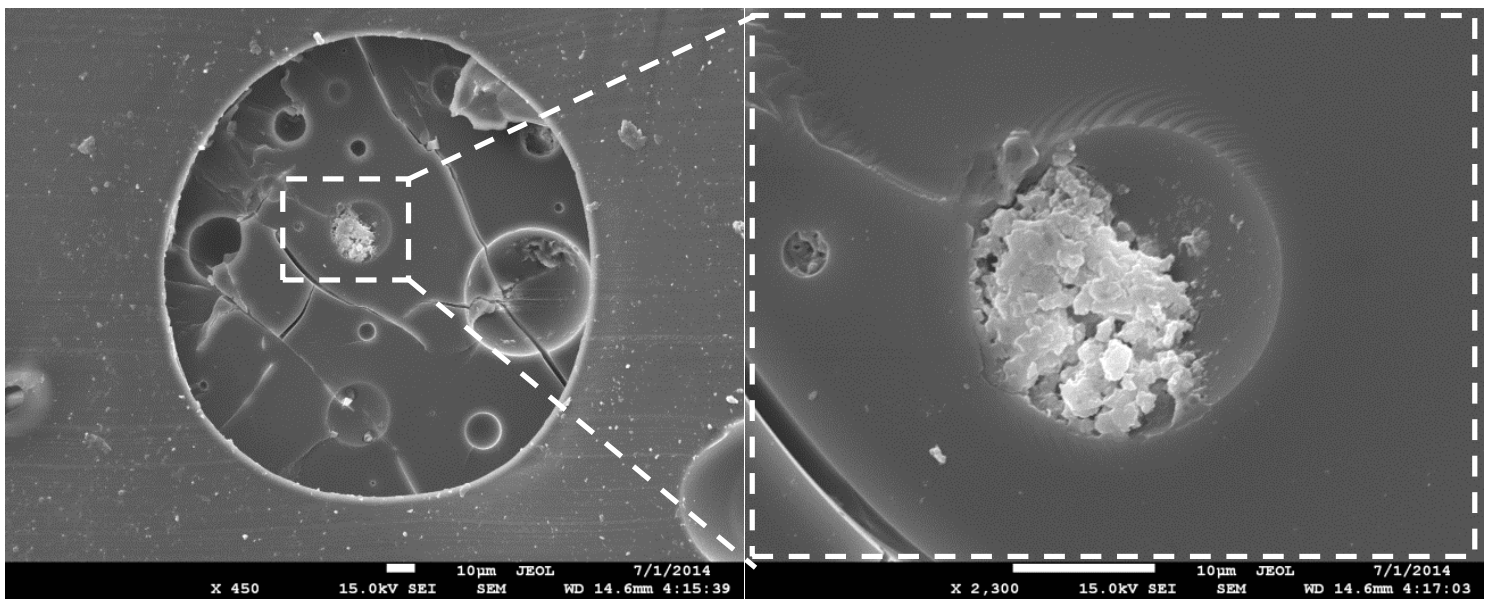

Figura 30: Micrografia de MEV da amostra 3 dos polímeros obtidos a partir de $5 \%$ de lignina natural.

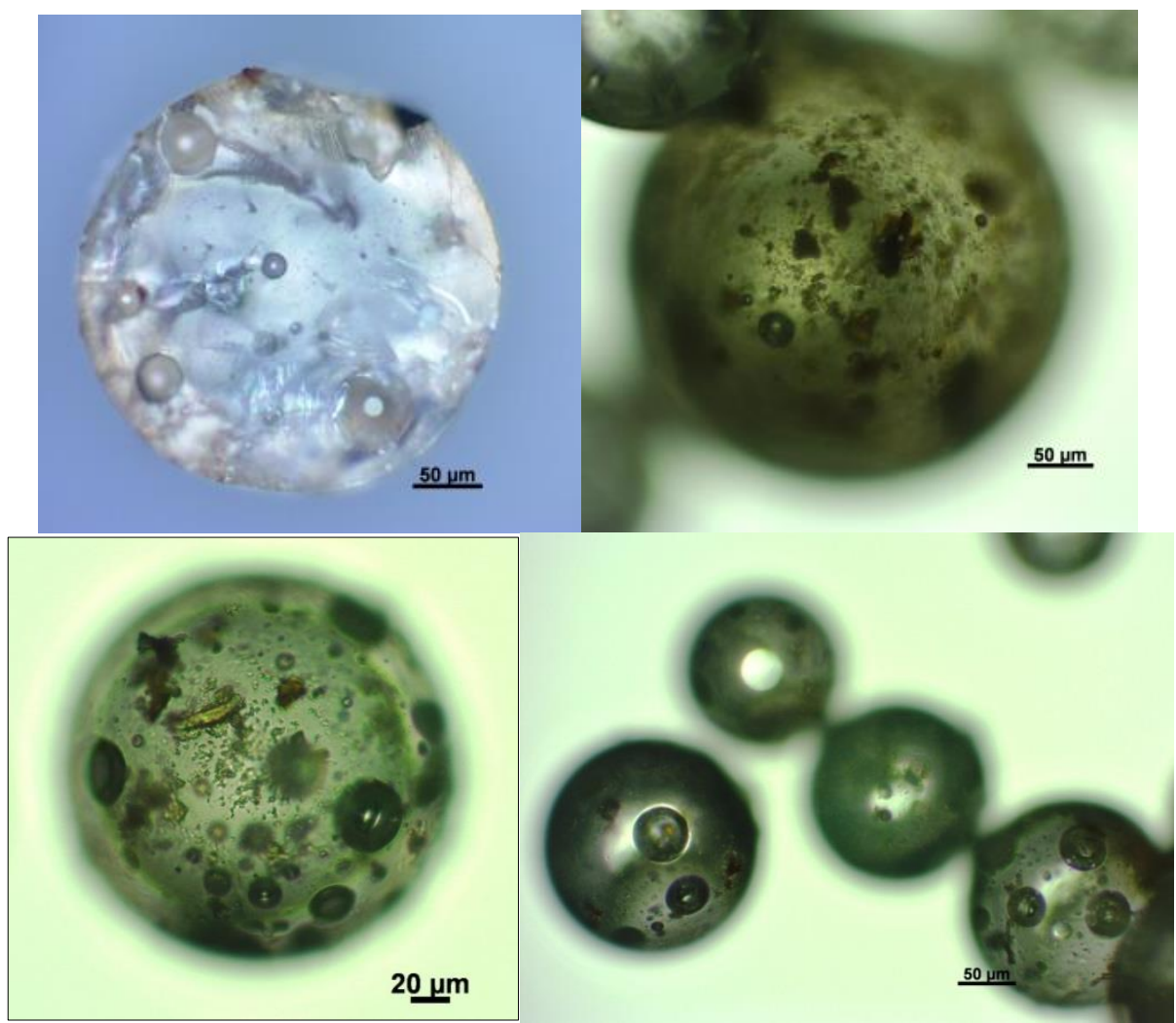

Figura 31: Imagens de microscopia ótica dos polímeros obtidos a partir de $5 \%$ de lignina natural.

Nas reações de polimerização com $10 \%$ de lignina foi utilizado os mesmos parâmetros de 5 \%, com 2,03 g de iniciador e a solução de PVA de $5 \mathrm{~g} / \mathrm{L}$. Contudo ao retirar do reator notou-se que a reação não foi estável, o polímero, após filtragem, era similar a uma pasta que, após seco, apresentou morfologia irregular (Figura 32) e baixa conversão em torno de 78 \% (Amostra 5), o que é explicado devido a baixa concentração do iniciador BPO. 


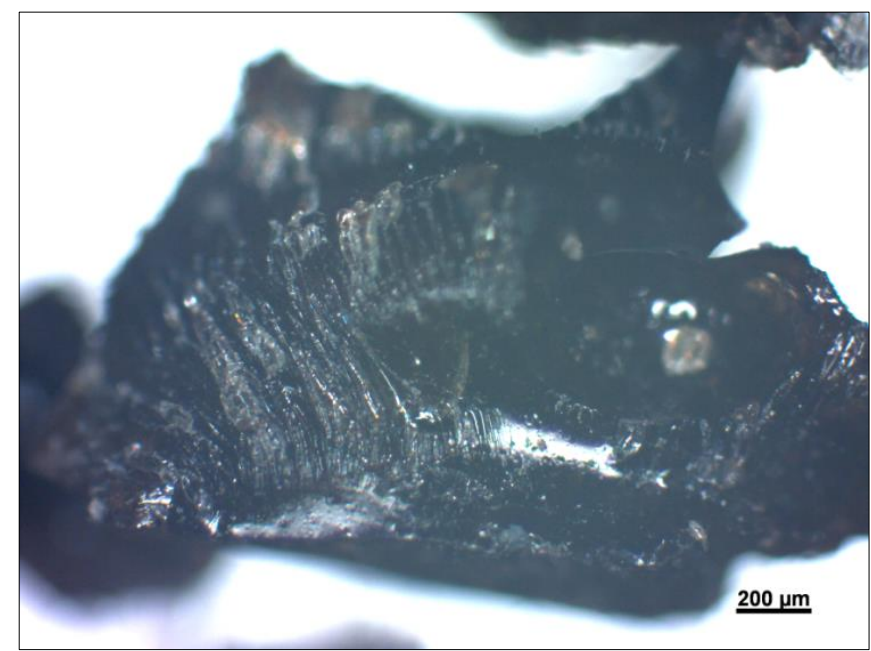

Figura 32: Imagens de microscopia ótica da Amostra 5 dos polímeros obtidos a partir de $10 \%$ de lignina natural e conversão de 78,3 \%.

Então a outra reação foi conduzida com a quantidade de iniciador de 4,06 g e solução de PVA de $5 \mathrm{~g} / \mathrm{L}$. Essa reação não produziu partículas esféricas (Figura 33) devido a baixa concentração de agente de suspensão e, consequentemente houve uma baixa conversão 84,3 \% (Amostra 6). A despeito da elevação observada na conversão, a quantidade de BPO usado ainda não foi suficiente para garantir conversões elevadas, cujo comportamento resulta da ação do BPO sobre a oxidação da lignina. É bem sabido que o BPO é um forte agente oxidante ${ }^{64,65}$, e naturalmente, uma parcela deste iniciador não estará disponível para polimerização do estireno, conduzindo a conversões baixas.

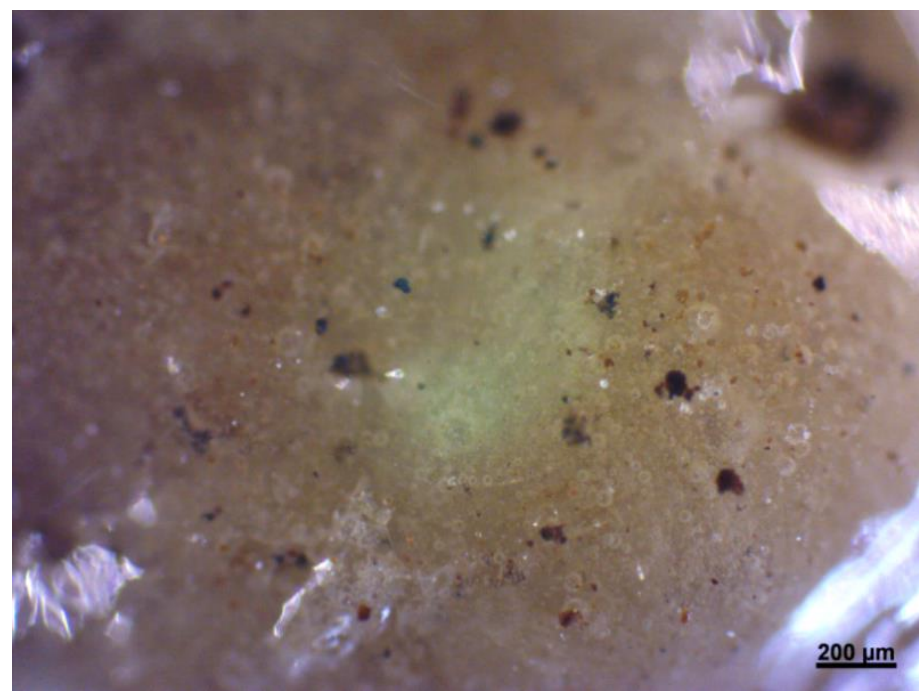

Figura 33: Imagens de microscopia ótica dos polímeros obtidos a partir de $10 \%$ de lignina natural e conversão de $84,3 \%$. 
Para minimizar o efeito indesejável da oxidação da lignina sobre a conversão de estireno e estabilidade do meio reacional, a concentração de PVA nas reações com $10 \%$ de lignina passou a ser de $7 \mathrm{~g} / \mathrm{L}$, o que proporcionou uma melhor estabilidade das partículas e conversão de 97,8 \% (Amostra 7). Posteriormente, essa amostra foi utilizada para os ensaios de viscosidade. As Figuras 34 e 35 mostram a morfologia dos polímeros formados, onde é também possível visualizar a existência de macrocavidades (Figura 34), e que a lignina foi homogeneamente dispersa na matriz termoplástica de estireno (Figura 35).

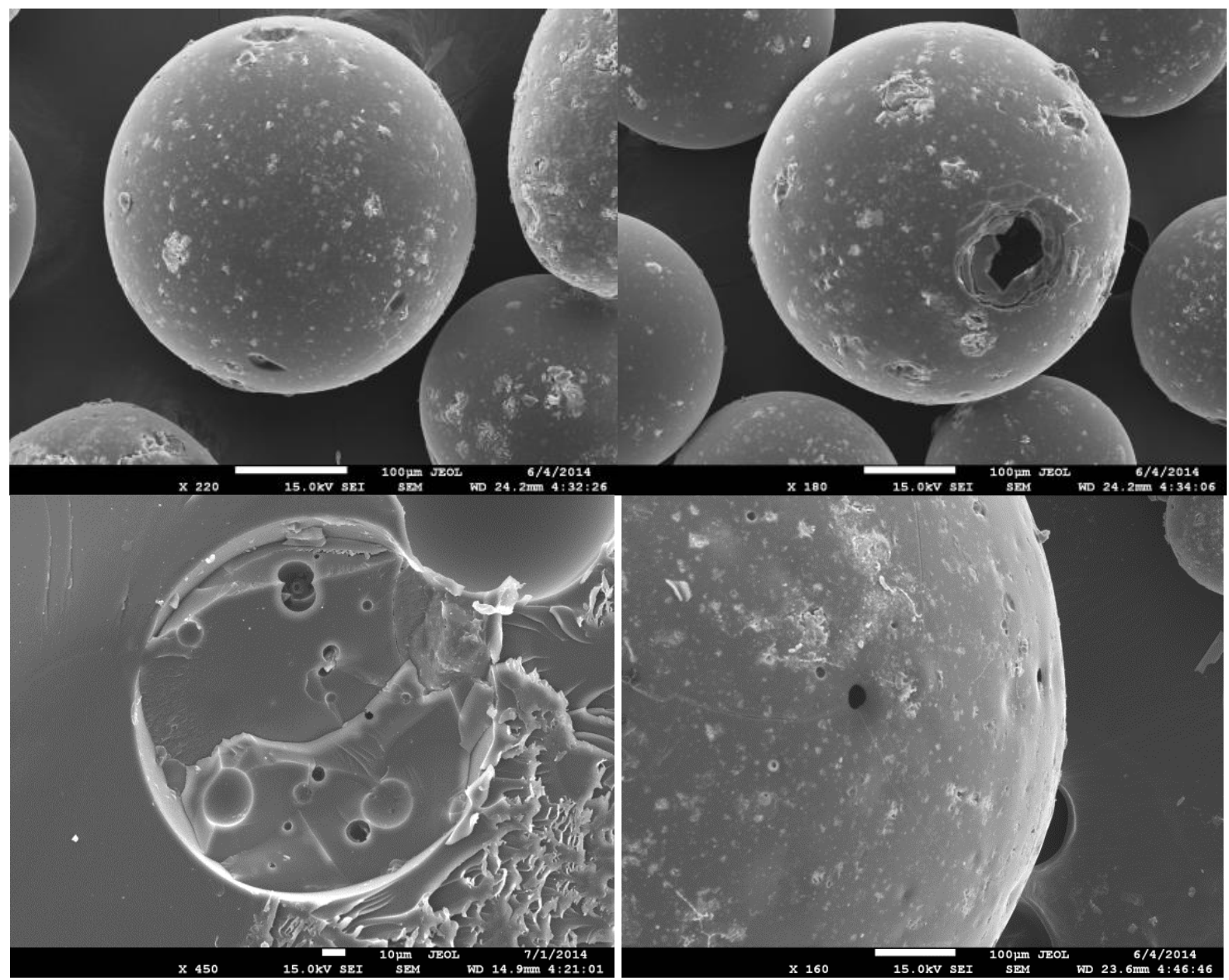

Figura 34: Micrografia de MEV da Amostra 7 dos polímeros obtidos a partir de $10 \%$ de lignina natural. 


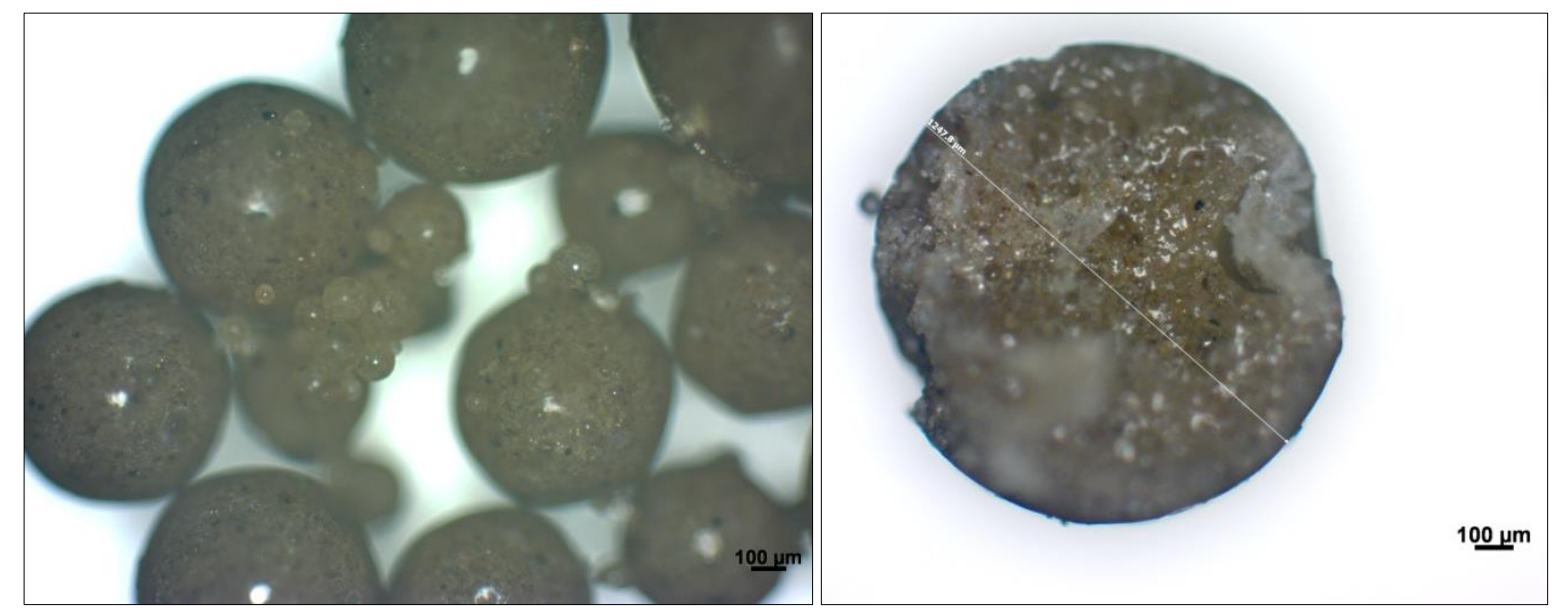

Figura 35: Imagens de microscopia ótica da amostra 7 dos polímeros obtidos a partir de $10 \%$ de lignina natural e conversão de $97,8 \%$.

Para as reações com $20 \%$ de lignina foi utilizado $10 \mathrm{~g} / \mathrm{L}$ de PVA. O aumento dessa concentração proporciona uma melhor eficácia do agente de suspensão (PVA) sobre a estabilidade do meio reacional. Já o aumento da massa do iniciador, passando para $9 \mathrm{~g}$, é necessário para compensar o aumento da fração de lignina no meio reacional, dada a sua suscetibilidade oxidação pelo iniciador, que em última instância conduziria à redução na conversão de monômero. Com base no rendimento da reação, equivalente a 98,8 \%, é razoável considerar que a concentração de BPO usada foi suficiente para garantir o suprimento apropriado de radicais de iniciador durante a reação. A Figura 36 mostra a imagem dos materiais poliméricos empregados nos ensaios de viscosidade.

$\mathrm{Na}$ imagem é possível observar a mudança de coloração de acordo com o aumento da concentração de lignina no polímero, ou seja, quanto maior a concentração de lignina mais escuro o polímero será. 

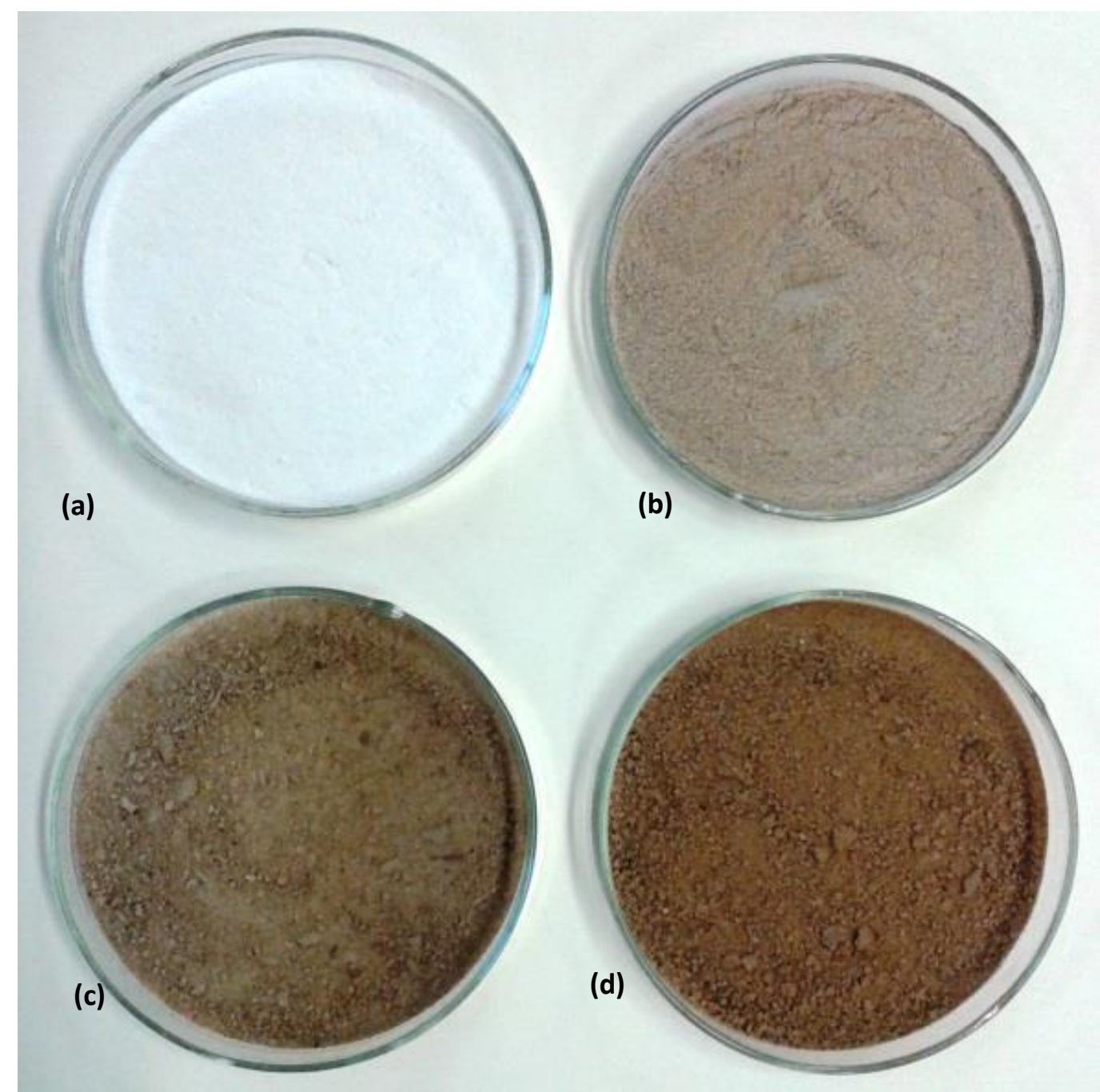

(b)

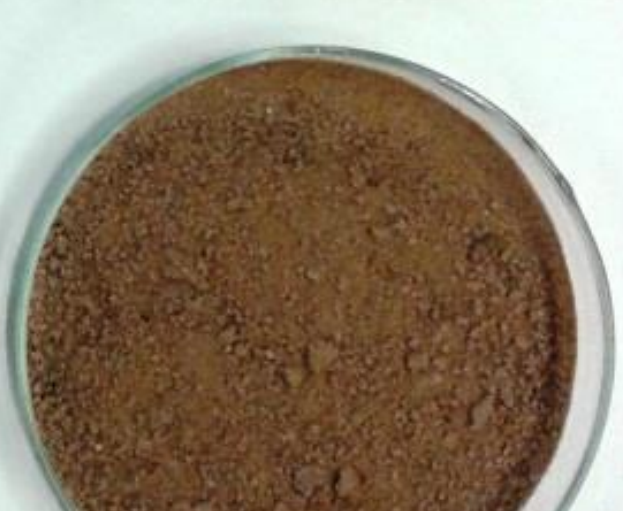

(d)

Figura 36: Imagem dos polímeros obtidos, onde: (a) poliestireno, (b) $5 \%$ de lignina natural, (c) $10 \%$ de lignina natural e (d) $20 \%$ de lignina natural.

\subsection{POLIMERIZAÇÃO EM MASSA-SUSPENSÃO COM ESTIRENO E LIGNINA ESTERIFICADA}

Os compósitos poliméricos foram formados partir de lignina esterificada com tamanho médio de $75 \mu \mathrm{m}-100 \mu \mathrm{m}$ e estireno. A reação de polimerização seguiu a mesma sequência da polimerização com lignina natural, onde a primeira etapa foi mantida sob agitação de $1.000 \mathrm{rpm}$ e a segunda etapa, após adição de PVA, foi conduzida sob agitação de $500 \mathrm{rpm}$, pois nas reações com lignina natural esse procedimento foi o de maior conversão. A Tabela 9 apresenta as condições experimentais das reações com $5 \%, 10 \%$ e $20 \%$ e suas respectivas conversões. 
Tabela 9: Condições experimentais dos processos de polimerização em massa-suspensão usando lignina esterificada.

\begin{tabular}{c|cccccc}
\hline \hline Amostras & $\begin{array}{c}\text { Lignina } \\
\text { esterif. (\%) }\end{array}$ & $\begin{array}{c}\text { Estireno } \\
(\mathbf{g})\end{array}$ & $\begin{array}{c}\text { Lignina } \\
\text { esterif. }(\mathbf{g})\end{array}$ & PVA (mL) & BPO (g) & $\begin{array}{c}\text { Conversão } \\
(\%)\end{array}$ \\
\hline 1 & 5 & 58,054 & 2,902 & $135(5 \mathrm{~g} / \mathrm{L})$ & 2,041 & 93,7 \\
2 & 5 & 58,102 & 2,923 & $135(5 \mathrm{~g} / \mathrm{L})$ & 2,039 & 85,2 \\
3 & 5 & 58,124 & 2,972 & $135(7 \mathrm{~g} / \mathrm{L})$ & 2,035 & 86,3 \\
4 & 5 & 58,098 & 2,939 & $135(10 \mathrm{~g} / \mathrm{L})$ & 2,036 & 98,8 \\
5 & 10 & 58,078 & 5,883 & $135(30 \mathrm{~g} / \mathrm{L})$ & 4,067 & 98,7 \\
6 & 20 & 58,034 & 5,834 & $135(30 \mathrm{~g} / \mathrm{L})$ & 4,071 & 83,1 \\
7 & 20 & 58,119 & 11,601 & $135(50 \mathrm{~g} / \mathrm{L})$ & 9,011 & 99,1 \\
\hline
\end{tabular}

Nas reações com $5 \%$ de lignina esterificada utilizou-se a mesma concentração de agente suspensão de lignina natural, no caso $5 \mathrm{~g} / \mathrm{L}$, mas com uma diferença, a polimerização foi apenas em suspensão, pois, após modificação houve um aumento da solubilidade da lignina em estireno. Contudo as imagens de MEV (Figura 37) mostraram uma baixa incorporação da lignina no polímero, acúmulos de lignina na superfície do polímero e estruturas de ligninas livres sem incorporação. Também foi possível, através da aproximação da imagem, observar partículas de lignina no interior de uma macrocavidade. O rendimento dessa reação foi de 93,7 \% (Amostra 1).

Estes resultados mostram que a modificação parcial da lignina não garante que a mesma será totalmente distribuída homogeneamente na matriz termoplástica de poliestireno. Como uma tentativa de minimizar a segregação de fases, por razões práticas, as reações com lignina esterificada também passaram a ser conduzidas via polimerização sequencial em massa suspensão. Na reação com $5 \%$ de lignina esterificada utilizou-se os mesmos parâmetros da reação com lignina natural, no caso $5 \mathrm{~g} / \mathrm{L}$ de PVA e 2,03 g de iniciador. Entretanto não ficou estável, e houve uma baixa conversão de 85,2 \% (Amostra 2). Então a concentração de PVA foi aumentada para $7 \mathrm{~g} / \mathrm{L}$ nas próximas reações, contudo não ficou estável, devido a baixa concentração de agente de suspensão, e também houve uma baixa conversão de $86,3 \%$ (Amostra 3). 


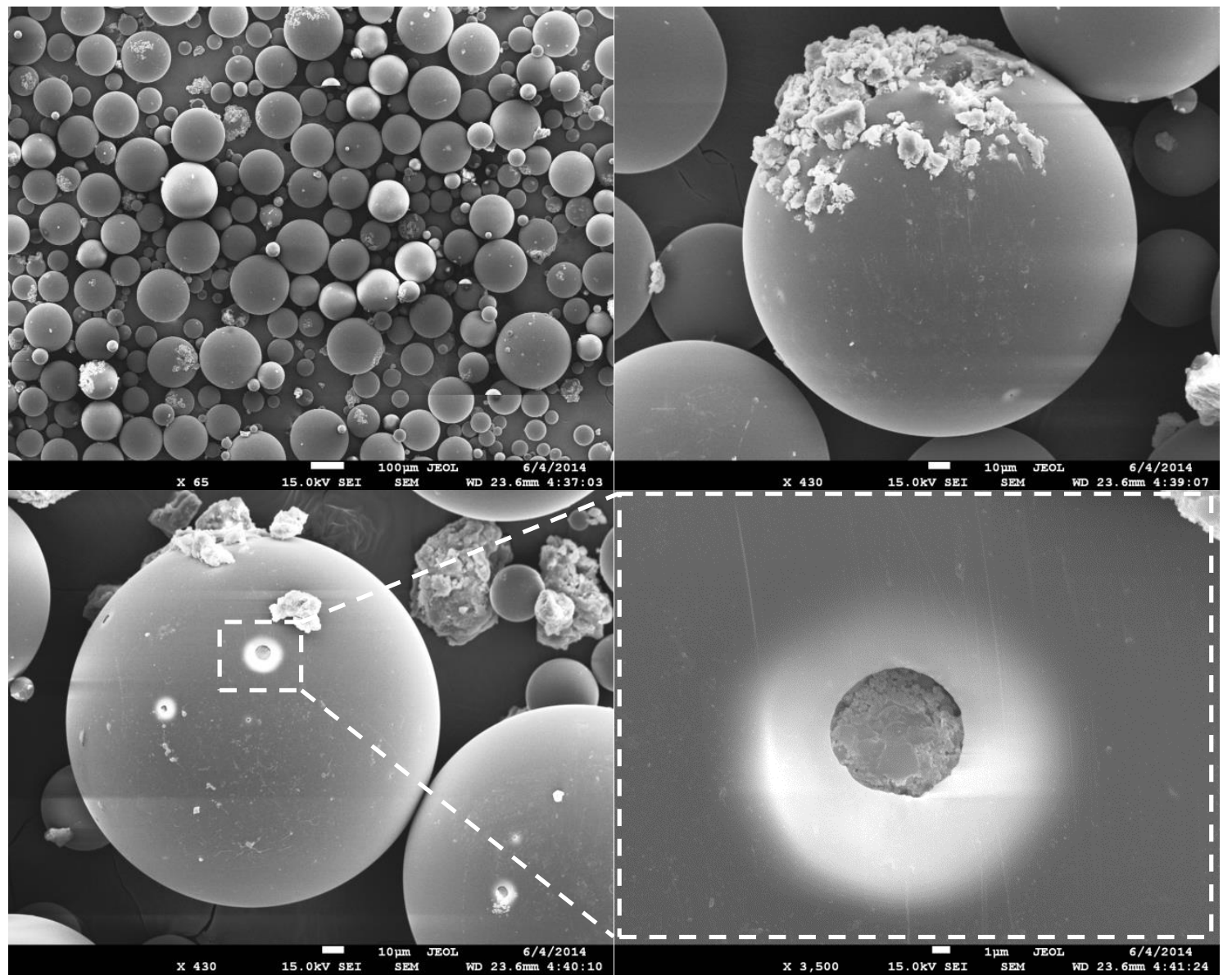

Figura 37: Micrografia de MEV da Amostra 1 dos polímeros obtidos a partir de $5 \%$ de lignina esterificada, na polimerização em suspensão.

Depois utilizou-se $10 \mathrm{~g} / \mathrm{L}$ de agente suspensão e 2,03 $\mathrm{g}$ de iniciador. Os polímeros formados não tiveram formas esféricas (devido a baixa agitação) como os polímeros com lignina natural, mas ficaram estáveis, porosos (Figura 38) e com uma conversão de 98,8 \% (Amostra 4). Na Figura 39 são apresentadas as imagens de microscopia ótica da superfície e o interior dos polímeros formados, onde é possível observar a incorporação da lignina. Nas imagens foi possível concluir que as grandes partículas de polímeros formados são na realidade acúmulos de pequenas partículas. As partículas de polímeros com lignina esterificada, por serem grandes, não houve a necessidade que fossem cortadas por microtomia, nas imagens que seguem as partículas foram quebradas manualmente. 


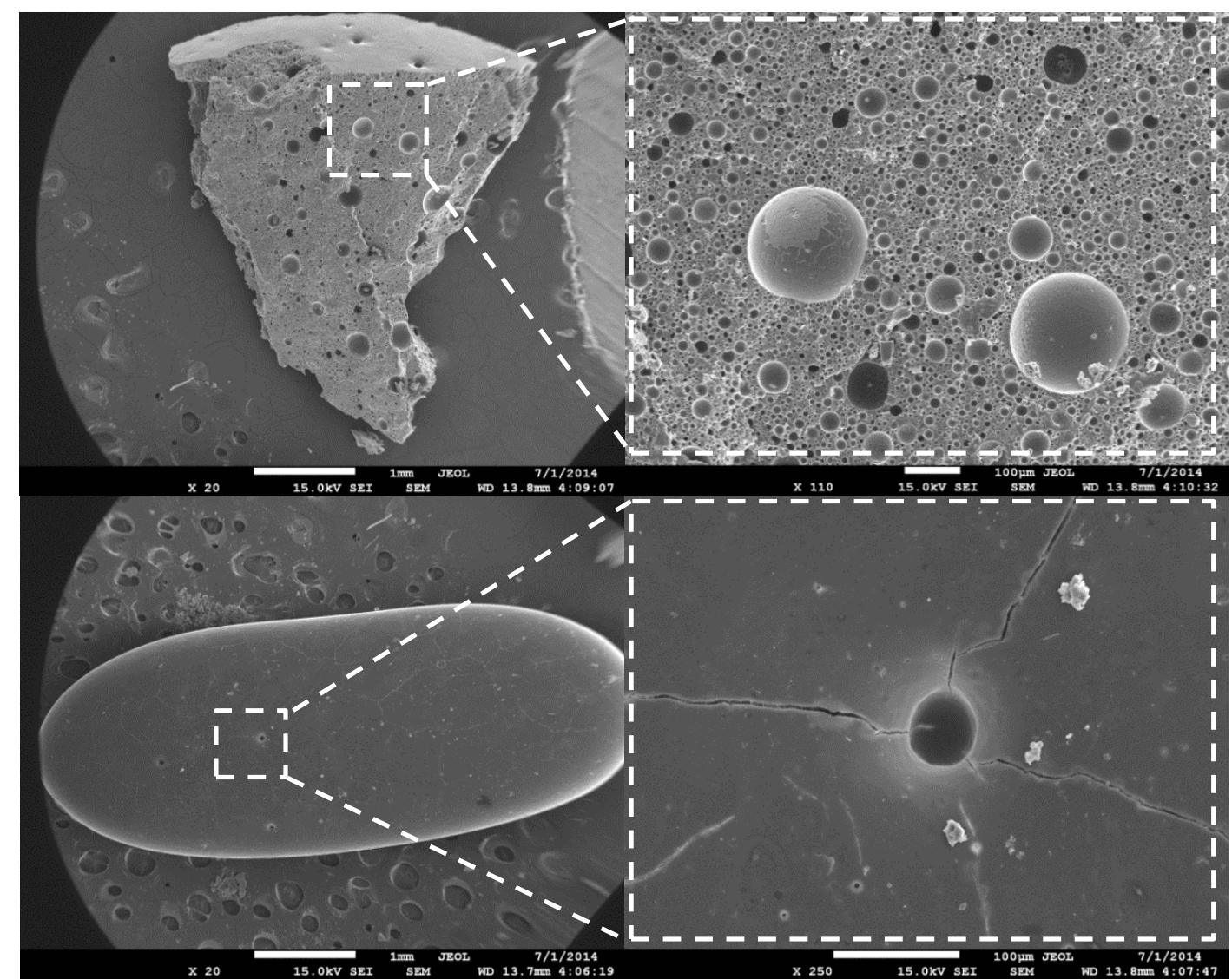

Figura 38: Micrografia de MEV da amostra 4 dos polímeros obtidos a partir de $5 \%$ de lignina esterificada.

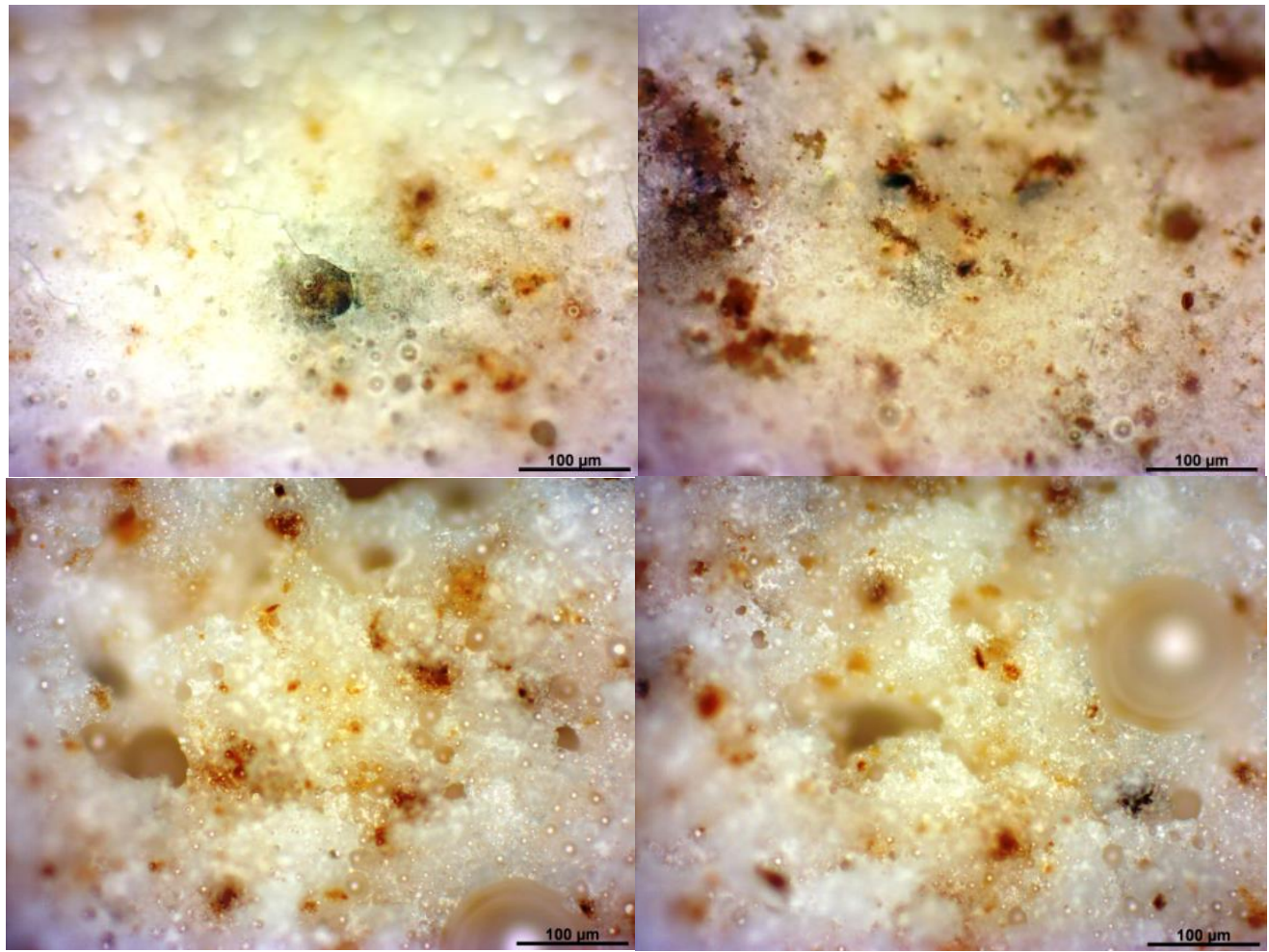

Figura 39: Imagens de microscopia ótica da amostra 4 dos polímeros obtidos a partir de $5 \%$ de lignina esterificada. 
$\mathrm{Na}$ reação com $10 \%$ de lignina esterificada (Amostra 5), para aumentar a estabilidade, a solução de agente suspensão foi aumentada para $30 \mathrm{~g} / \mathrm{L}$. Os polímeros formados apresentaram morfologia esférica (como resultado da estabilidade do meio reacional) e elevada porosidade (como consequência da migração de microgotas de água, previamente encapsuladas na matriz polimérica, para o meio reacional) (Figura 40 e 41) e a conversão foi em torno de $98,7 \%$.

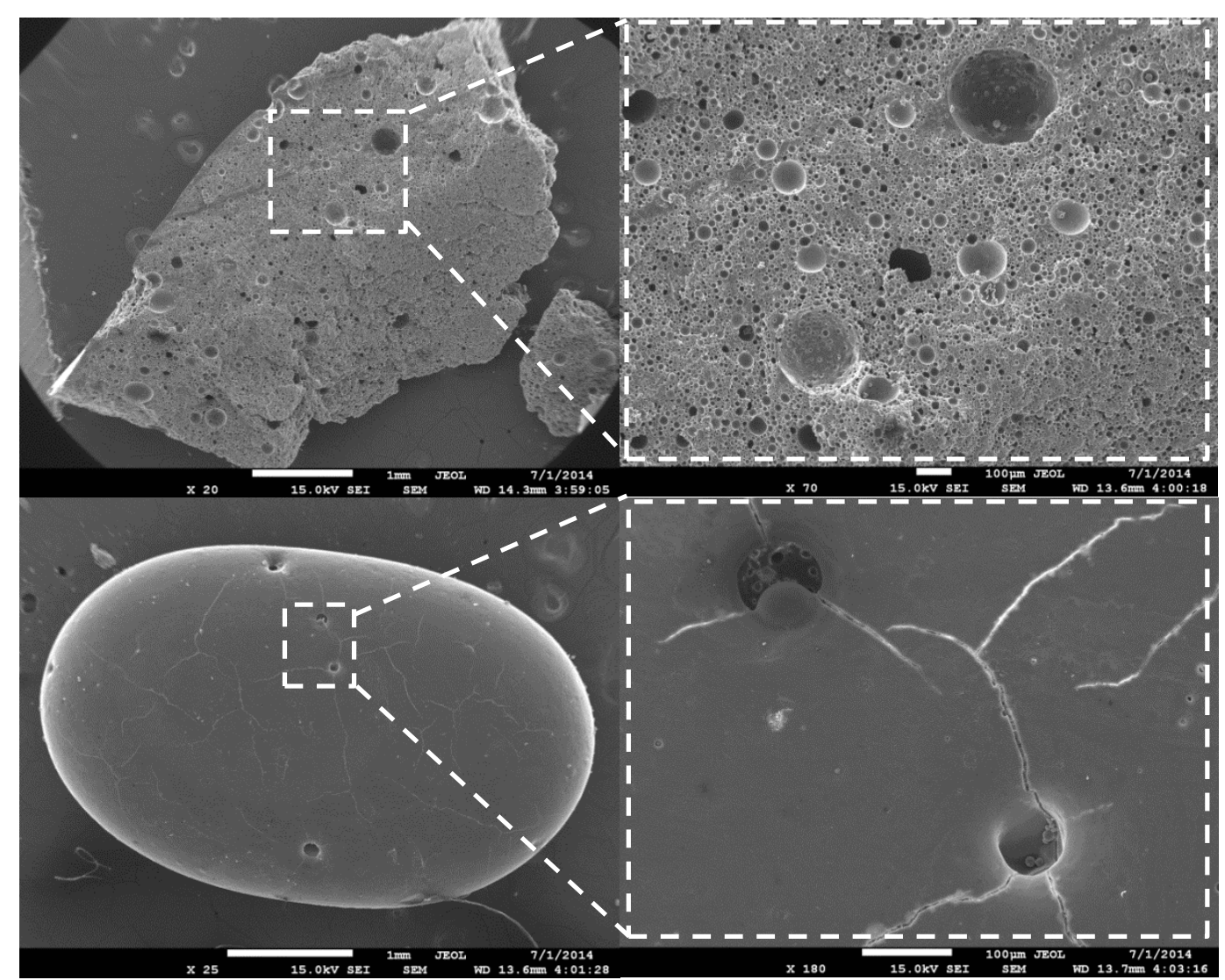

Figura 40: Micrografia de MEV da amostra 5 dos polímeros obtidos a partir de $10 \%$ de lignina esterificada.

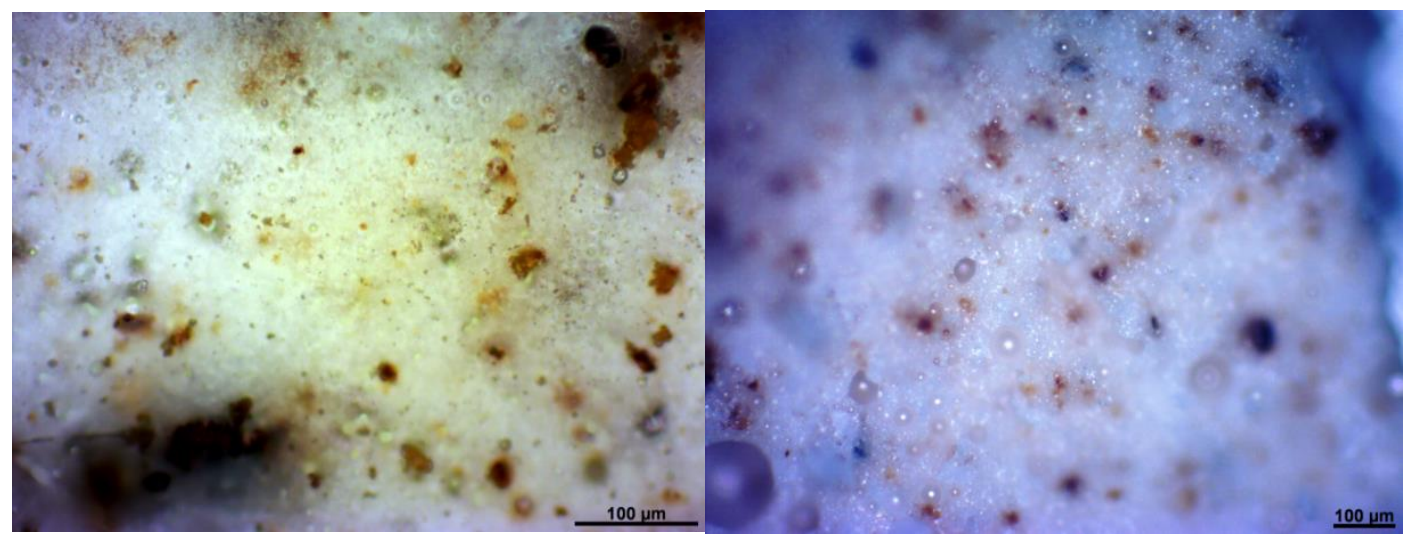

Figura 41: Imagens de microscopia ótica da amostra 5 dos polímeros obtidos a partir de $10 \%$ de lignina esterificada. 
Em reações com $20 \%$ de lignina esterificada, a solução de agente suspensão foi de $30 \mathrm{~g} / \mathrm{L}$, assim como na reação com $10 \%$, mas não houve êxito, pois o polímero formado apresentou baixo rendimento de 83,1 \% (Amostra 6). Então aumentou-se o PVA para $50 \mathrm{~g} / \mathrm{L}$ e nesse caso a agitação na segunda fase de reação foi de $800 \mathrm{rpm}$, com o objetivo de diminuir o tamanho da partícula e tentar obter polímeros esféricos. Os polímeros formados também foram porosos e dessa vez tiveram uma forma mais esférica que os outros, como mostrado na Figura 39, e uma excelente conversão de 99,1 \% (Amostra 7). As Figuras 42 e 43 apresentam imagens dos polímeros.

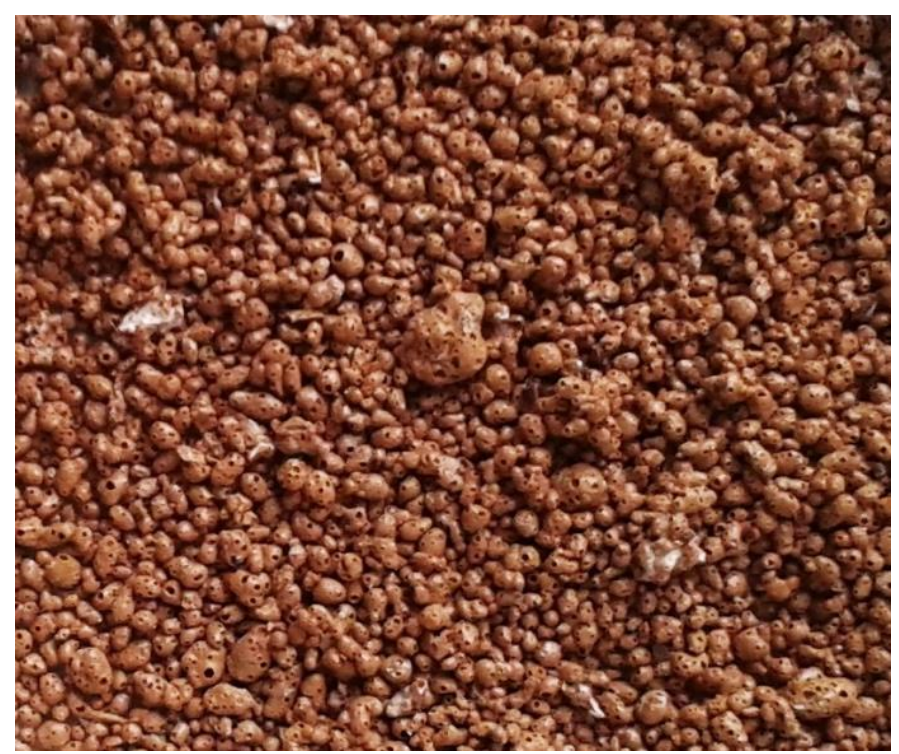

Figura 42: Imagens dos polímeros obtidos a partir de $20 \%$ de lignina esterificada e $50 \mathrm{~g} / \mathrm{L}$ de solução de agente de suspensão.

De acordo com a Figura 43, é possível observar as diferenças morfológicas entre os polímeros formados com lignina esterificada, de tal forma que, podemos inferir que quanto maior a velocidade de rotação na segunda fase da reação menor será o tamanho da partícula, como esperado.

De acordo com a Figura 44, é possível observar a mudança de coloração de acordo com o aumento da concentração de lignina no polímero, ou seja, quanto maior a concentração de lignina esterificada mais escuro o polímero será; e, em comparação a imagem dos polímeros com lignina natural, essas são mais escuras. Isso pode ser explicado devido ao aumento da solubilidade da lignina esterificada em estireno, ou seja, na primeira fase da reação há uma melhor incorporação na matriz polimérica. 

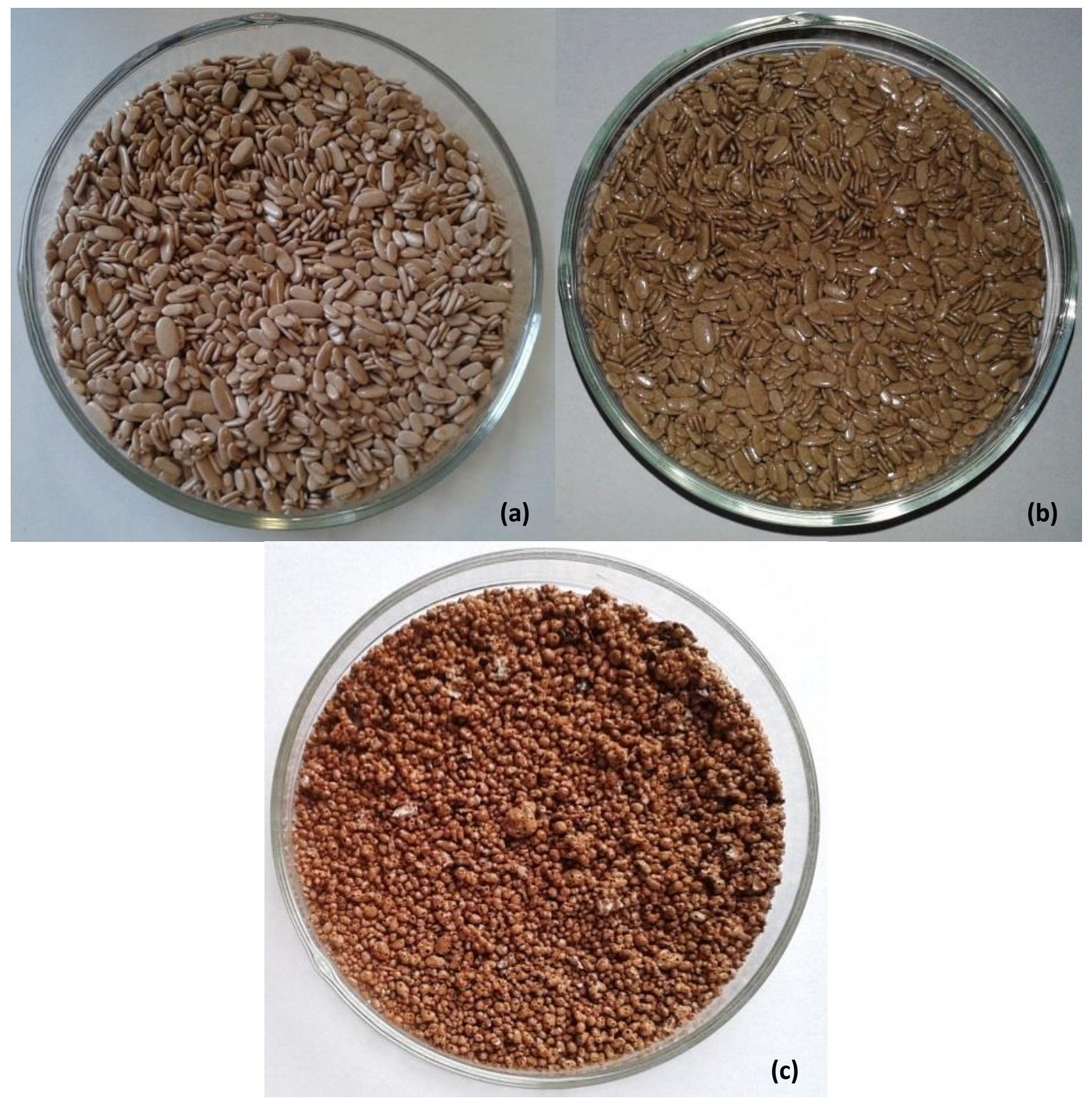

Figura 43: Imagens dos polímeros obtidos com estireno e lignina esterificada, onde: (a) $5 \%$ de lignina esterificada (Amostra 4), (b) $10 \%$ de lignina esterificada (Amostra5) e (c) $20 \%$ de lignina esterificada (Amostra 7). 


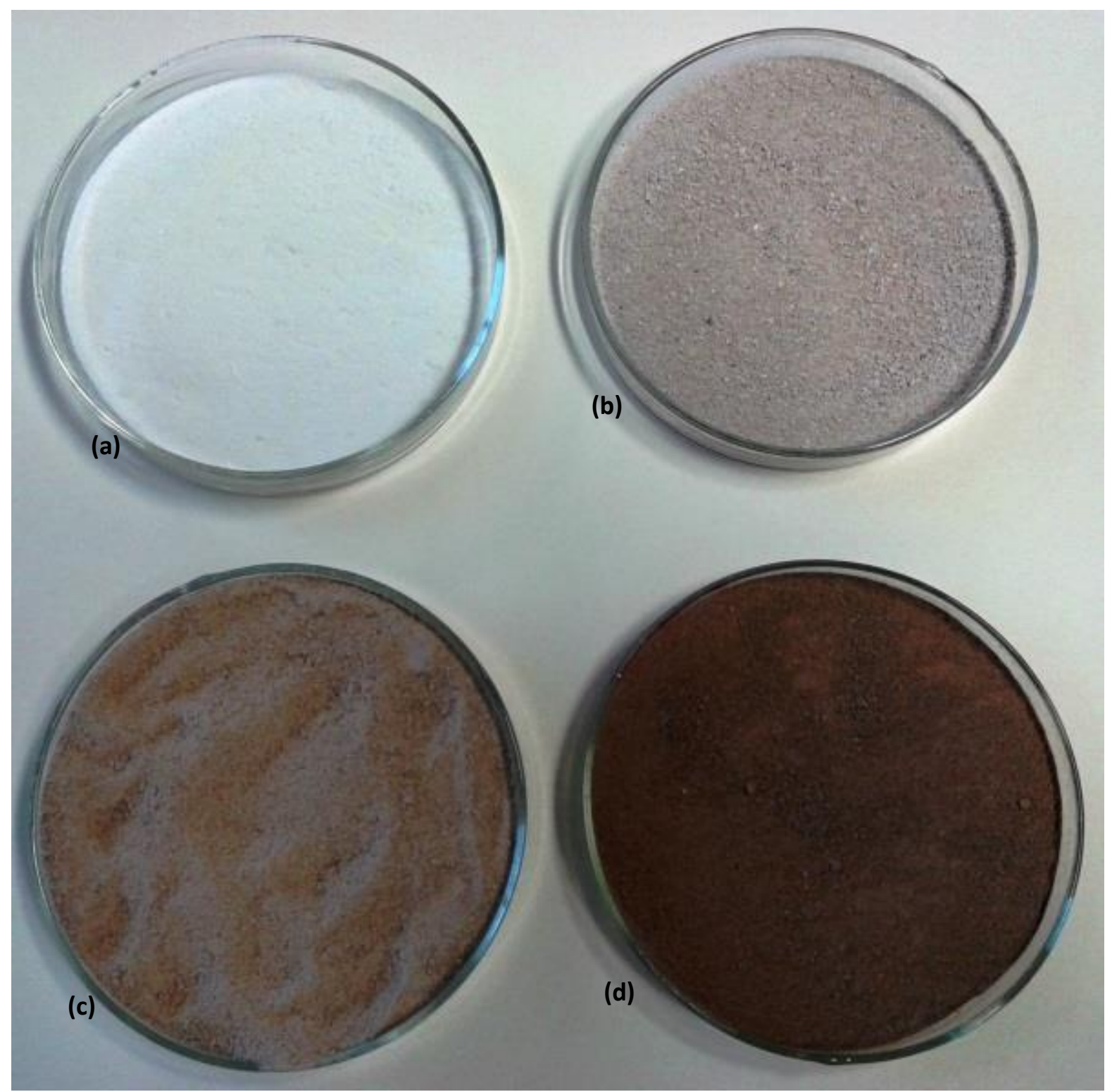

Figura 44: Imagem dos polímeros formados, onde: (a) poliestireno, (b) $5 \%$ de lignina esterificada, (c) $10 \%$ de lignina esterificada e (d) $20 \%$ de lignina esterificada.

\subsubsection{Considerações gerais e justificativas:}

1) A quantidade de iniciador utilizada em reações de polimerização em suspensão é geralmente de 0,1 a $0,5 \%$ em peso do monômero. ${ }^{14},{ }^{17}$ Para as reações com o uso de lignina e lignina esterificada esse valor foi de $3,5 \%$, ou seja, quase sete vezes mais. Isso pode ser explicado pelo fato da lignina ter um grande poder oxidativo. Com o aumento da concentração da lignina há também um aumento proporcional de iniciador, com o objetivo de garantir o crescimento da cadeia polimérica e restituir a parcela de iniciador que atua como agente oxidante. 
2) $O$ agente de suspensão e a agitação afetam diretamente 0 tamanho das partículas e sua forma, no caso do agente de suspensão também garante a ausência de coalescência. O PVA tem o papel de diminuir a tensão interfacial entre a água e o monômero, causando sua dispersão. Contudo, se uma amostra tiver um elevado número de hidroxilas, pode conduzir à ligações de hidrogênio intra e intermolecular fortes, impedindo a solubilidade do PVA na água. ${ }^{66}$

Nas reações de polimerização com lignina foi necessário o uso de uma grande concentração de PVA, devido a grande quantidade de hidroxilas presentes.

Para verificar a acidez do meio reacional após a adição de água, foi realizado o seguinte experimento: $3 \mathrm{~mL}$ de água deionizada foi colocada em 7 tubos falcon. No primeiro foi colocado apenas água deionizada, e nos outros seis foram preparadas soluções com lignina e lignina esterificada conforme as Tabelas 10 e 11 . $\mathrm{O} \mathrm{pH}$ foi medido. Foi possível observar que o meio reacional é realmente ácido. Isso explica a alta concentração de PVA necessária para estabilizar as gotas de monômeros na reação.

Tabela 10: Condições experimentais do teste de pH da lignina natural.

\begin{tabular}{c|ccc}
\hline \hline Lignina natural \% & Água $(\mathbf{m L})$ & Lignina $(\mathbf{g})$ & $\mathbf{p H}$ \\
\hline 0 & 3 & 0,0000 & 5,52 \\
5 & 3 & 0,0673 & 2,55 \\
10 & 3 & 0,1303 & 2,32 \\
20 & 3 & 0,2589 & 2,10 \\
\hline
\end{tabular}

Tabela 11: Condições experimentais do teste de pH da lignina esterificada.

\begin{tabular}{c|ccc}
\hline \hline $\begin{array}{c}\text { Lignina } \\
\text { esterificada \% }\end{array}$ & Água (mL) & Lignina (g) & pH \\
\hline 0 & 3 & 0,0000 & 5,52 \\
5 & 3 & 0,0652 & 2,67 \\
10 & 3 & 0,1299 & 2,54 \\
20 & 3 & 0,2598 & 2,46 \\
\hline
\end{tabular}




\subsection{ENSAIOS DE VISCOSIDADE E AVALIAÇÃO TÉRMICA DOS POLÍMEROS}

Para que houvesse um padrão nos ensaios de viscosidade três reações de formação de poliestireno puro foram realizadas com a quantidade de iniciador das reações com lignina e lignina esterificada, com o objetivo minimizar as diferenças que poderia ocorrer nas análises térmicas após os ensaios e eliminar a interferência da concentração de iniciador sobre o tamanho das cadeias poliméricas. Os dados das reações com estireno puro estão na Tabela 12.

Tabela 12: Dados experimentais dos processos de polimerização em massa-suspensão do estireno.

\begin{tabular}{c|cccc}
\hline \hline Amostras & Estireno (g) & PVA (mL) & BPO (g) & Conversão (\%) \\
\hline 1 & 58,059 & $135(5 \mathrm{~g} / \mathrm{L})$ & 2,039 & 95,8 \\
3 & 58,102 & $135(7 \mathrm{~g} / \mathrm{L})$ & 4,075 & 96,7 \\
5 & 58,187 & $135(10 \mathrm{~g} / \mathrm{L})$ & 9,043 & 98,6 \\
\hline
\end{tabular}

Nos ensaios de viscosidade, a temperatura pretendida era alcançada antes da introdução do porta-amostra contendo os polímeros, os quais foram finamente triturados e secos na capela a temperatura ambiente, para evitar liberação de solventes durante os ensaios. Após a introdução do porta-amostra, esperou-se a estabilidade de temperatura para a introdução do spindle 34. Ao introduzi-lo, esperou-se um tempo de aproximadamente 10 minutos para a acomodação do polímero em torno do spindle e controle de temperatura. Depois dessa sequência, ocorreu o início do ensaio. Após o ensaio, o polímero foi esfriado e uma parte foi separada para posterior análise de TGA e DSC, com o objetivo de verificar a degradação térmica dos polímeros.

Um estudo preliminar de viscosidade foi realizado com as amostras 3 do polímero com $5 \%$ de lignina pura e amostra 3 do polímero com $5 \%$ de lignina esterificada e uma amostra de poliestireno de uma reação com os mesmos parâmetros das reações de $5 \%$. Os ensaios foram realizados em 4 temperaturas (180 을 $190{ }^{\circ} \mathrm{C}, 200^{\circ} \mathrm{C}$ e $210^{\circ} \mathrm{C}$ ), com uma velocidade de 0,1 RPM e uma taxa de cisalhamento de $0,03 \mathrm{~s}^{-1}$. Os perfis de viscosidade dos polímeros estão na Figura 45, os dados de estabilidade térmica estão na Figura 46, as curvas de DSC estão na Figura 47 e os dados da caracterização térmica estão na Tabela 13. 
Os dados mostram que, em comparação ao poliestireno, as amostras contendo $5 \%$ de lignina natural e lignina esterificada tiveram um aumento significativo na viscosidade, isso devido ao fato da presença de lignina. Os polímeros apresentaram uma boa estabilidade térmica e os valores de transição vítrea $(\mathrm{Tg})$ se mantiveram praticamente constantes. Como base nestes resultados, podemos afirmar então que a incorporação de lignina na matriz polimérica de estireno melhora as propriedades térmicas do polímero.

Tabela 13: Caracterização térmica do poliestireno e dos polímeros formados com poliestireno/lignina $5 \%$ e poliestireno/lignina esterificada $5 \%$.

\begin{tabular}{|c|c|c|c|c|c|}
\hline $\begin{array}{l}\text { Iniciador e } \\
\% \text { de lignina }\end{array}$ & Amostra & $\begin{array}{l}\text { Ensaio de } \\
\text { viscosidade } \\
\left({ }^{\circ} \mathrm{C}\right)\end{array}$ & $\begin{array}{c}\text { Viscosidade } \\
\text { (cP) }\end{array}$ & $\operatorname{Tg}\left({ }^{\circ} \mathrm{C}\right)$ & $\begin{array}{c}\text { Conversão } \\
(\%)\end{array}$ \\
\hline & \multirow{5}{*}{ 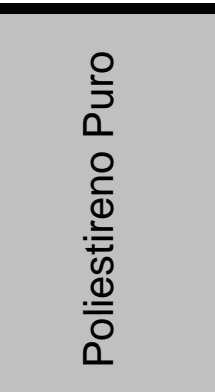 } & 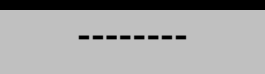 & & 94,50 & \multirow{5}{*}{96,9} \\
\hline & & 180 & 113976 & 94,21 & \\
\hline & & 190 & 62387 & 94,95 & \\
\hline & & 200 & 30594 & 94,45 & \\
\hline & & 210 & 24194 & 93,74 & \\
\hline \multirow{10}{*}{ 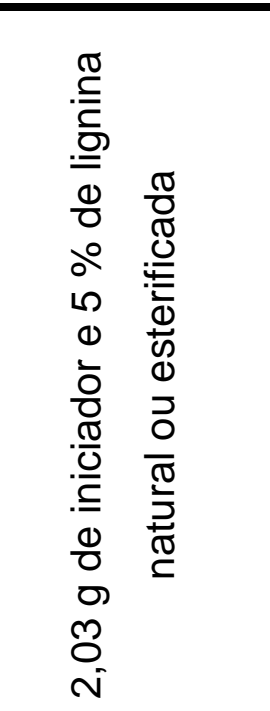 } & \multirow{5}{*}{ 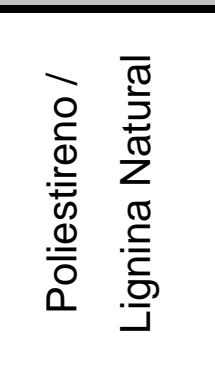 } & ------- & ------- & 85,55 & \multirow{5}{*}{97,3} \\
\hline & & 180 & 174653 & 88,90 & \\
\hline & & 190 & 121174 & 87,43 & \\
\hline & & 200 & 116375 & 89,31 & \\
\hline & & 210 & 95380 & 87,48 & \\
\hline & \multirow{5}{*}{ 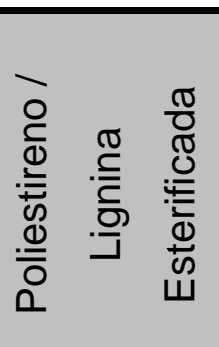 } & ------- & -------- & 94,48 & \multirow{5}{*}{86,3} \\
\hline & & 180 & 187760 & 91,87 & \\
\hline & & 190 & 134971 & 91,66 & \\
\hline & & 200 & 79783 & 93,09 & \\
\hline & & 210 & 57588 & 93,26 & \\
\hline
\end{tabular}




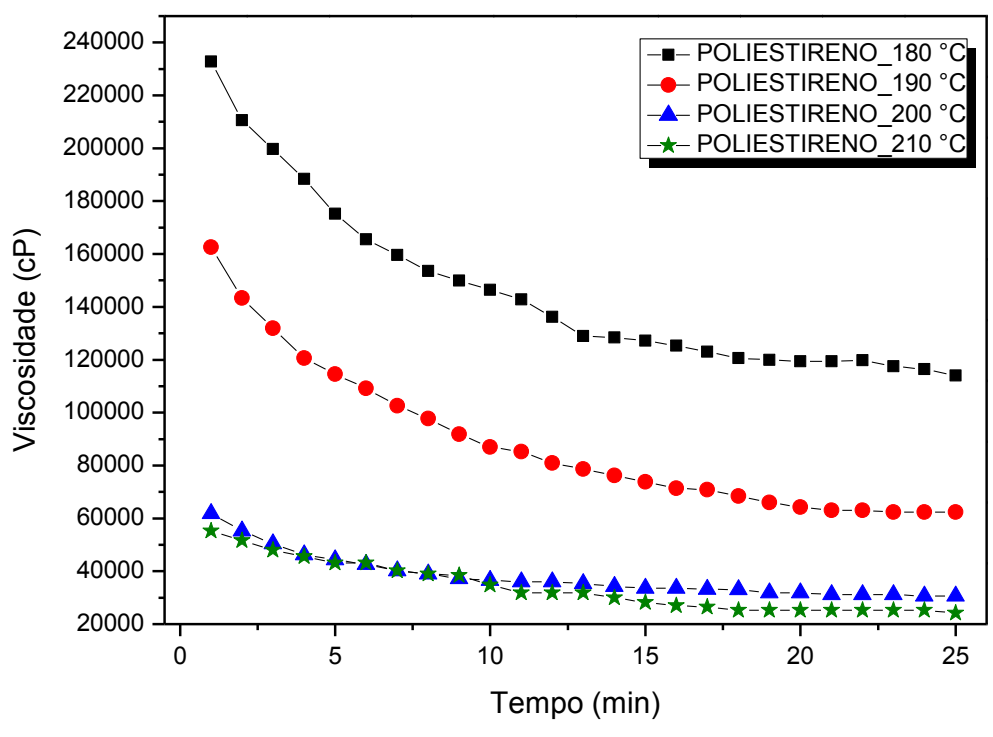

(a)

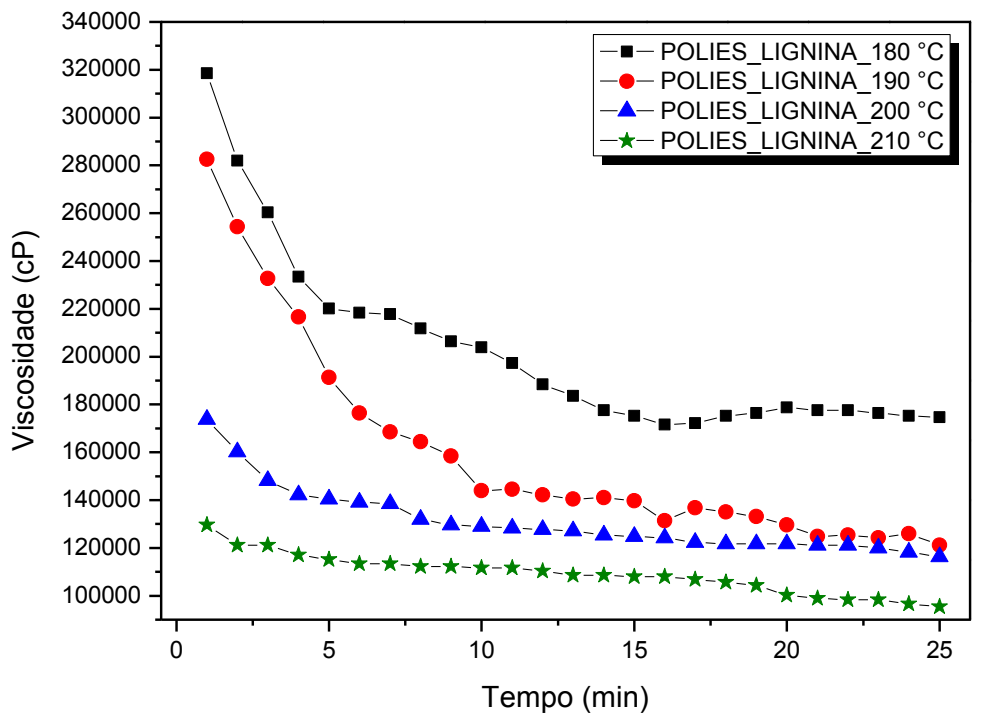

(b)

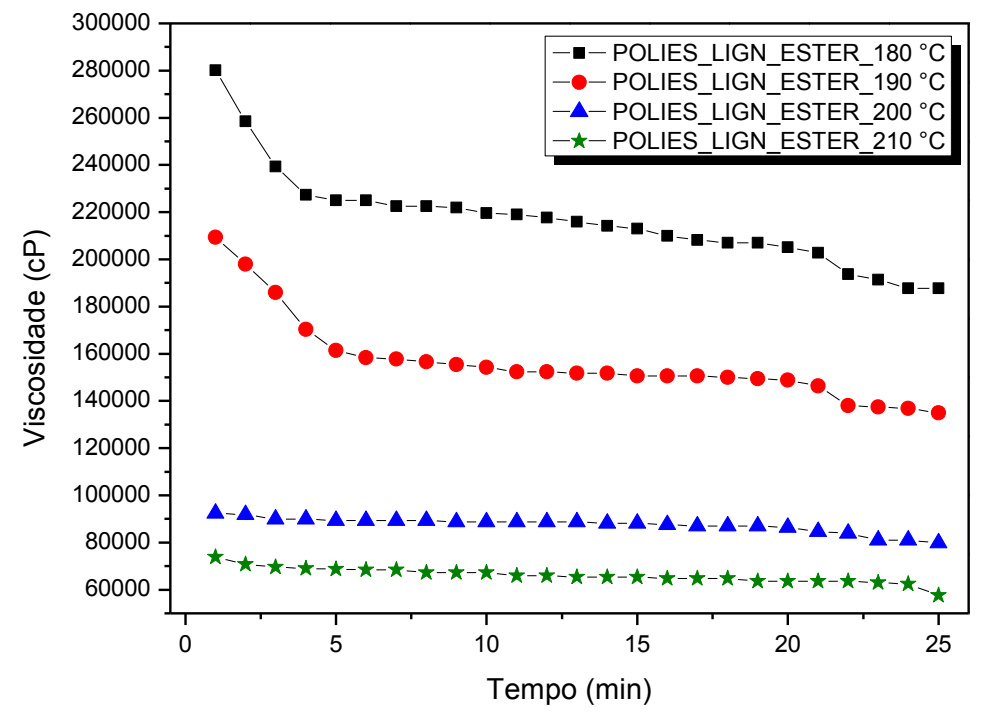

(c)

Figura 45: Perfis de viscosidade das amostras preliminares, onde: (a) poliestireno, (b) poliestireno/lignina $5 \%$ e (c) poliestireno/lignina esterificada $5 \%$. 


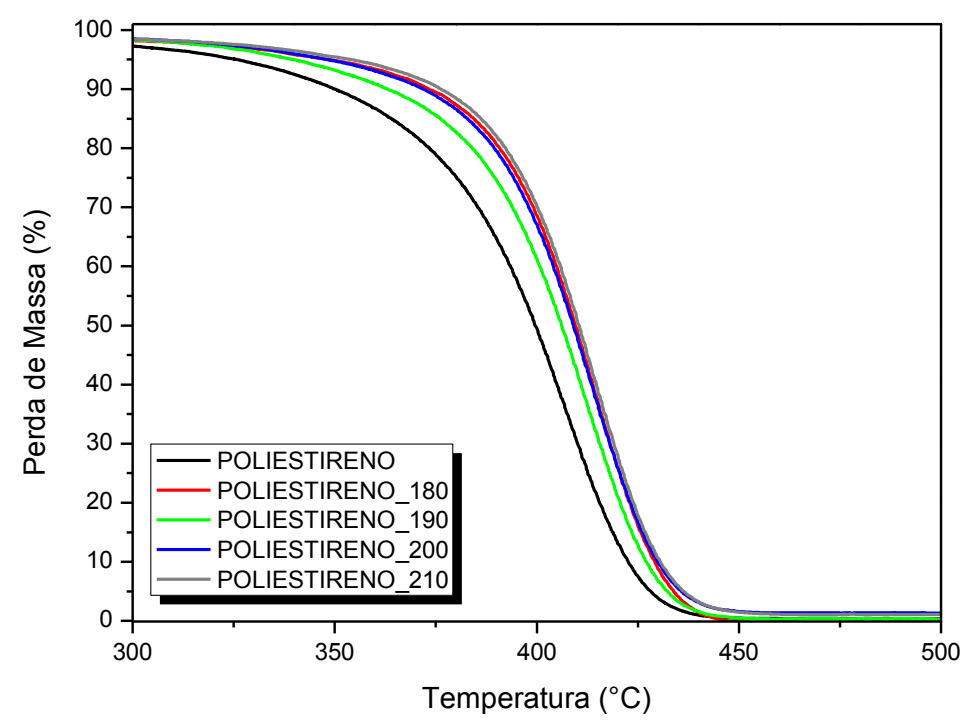

(a)

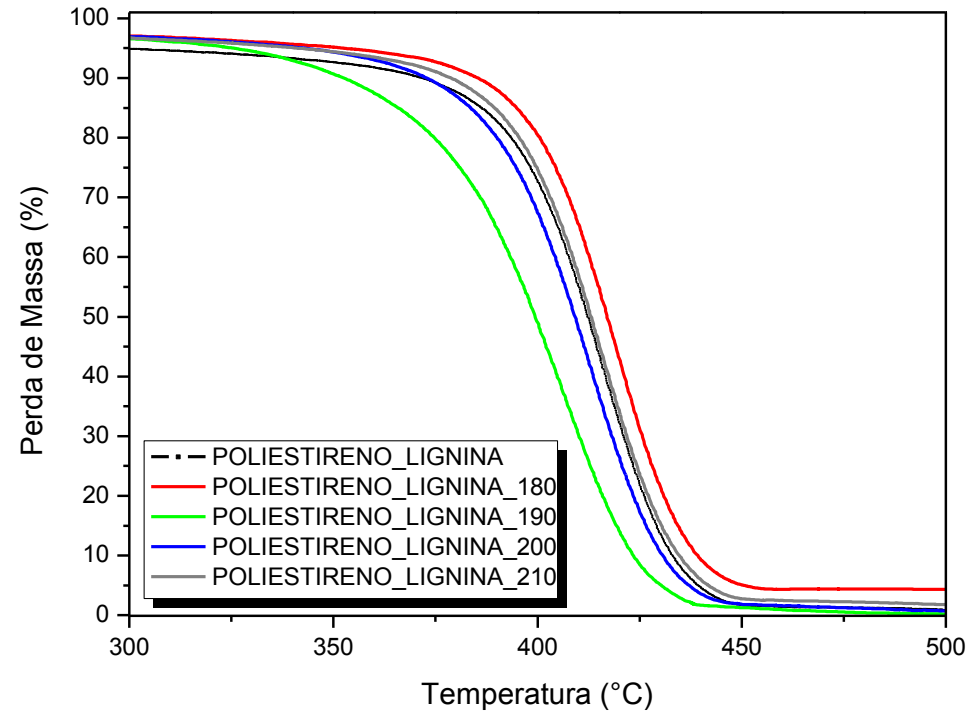

(b)

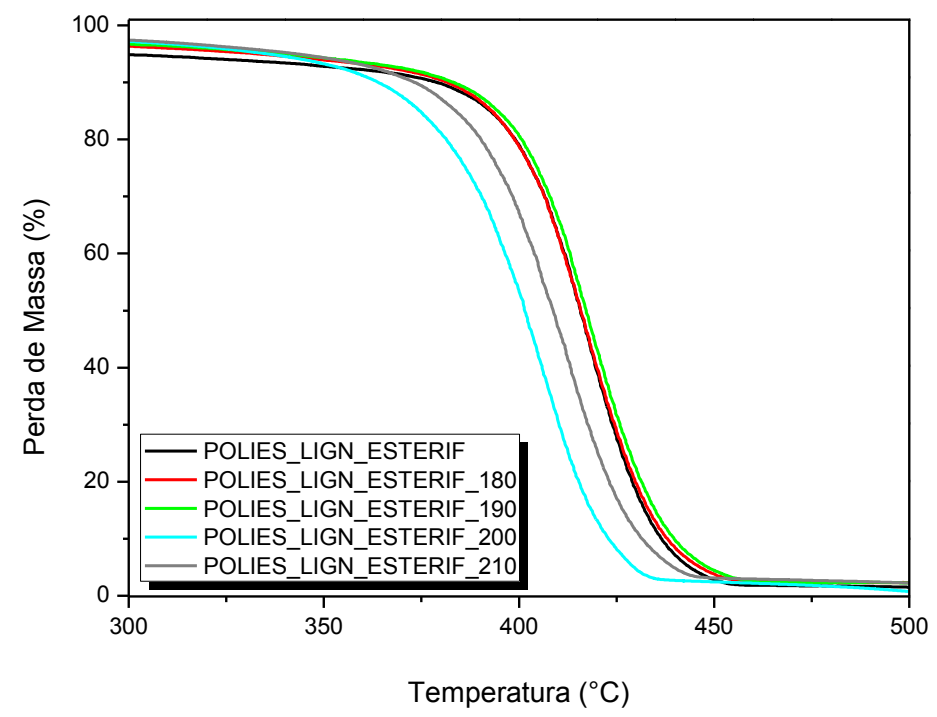

(c)

Figura 46: Estabilidade térmica das análises preliminares dos polímeros, onde: (a) poliestireno, (b) poliestireno/lignina $5 \%$ e (c) poliestireno/lignina esterificada $5 \%$. 


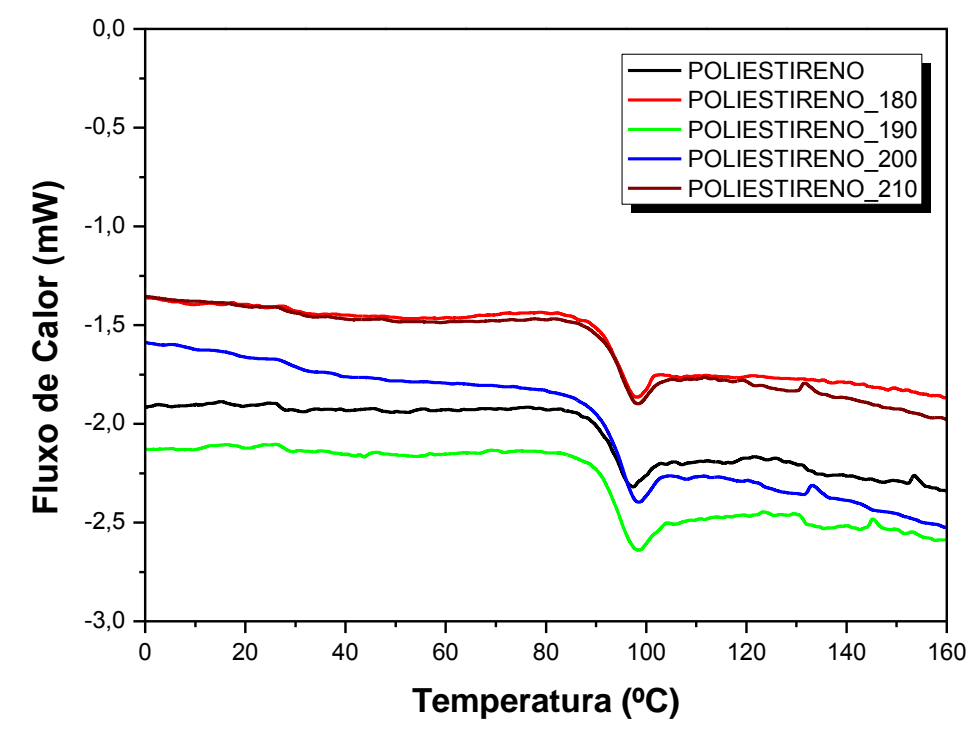

(a)

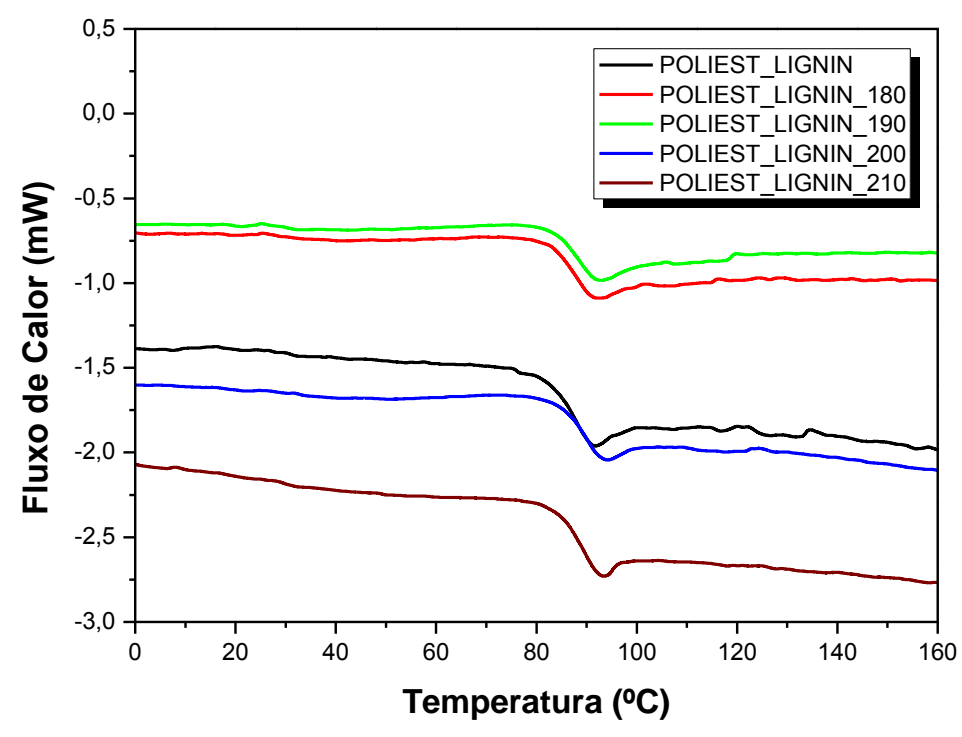

(b)

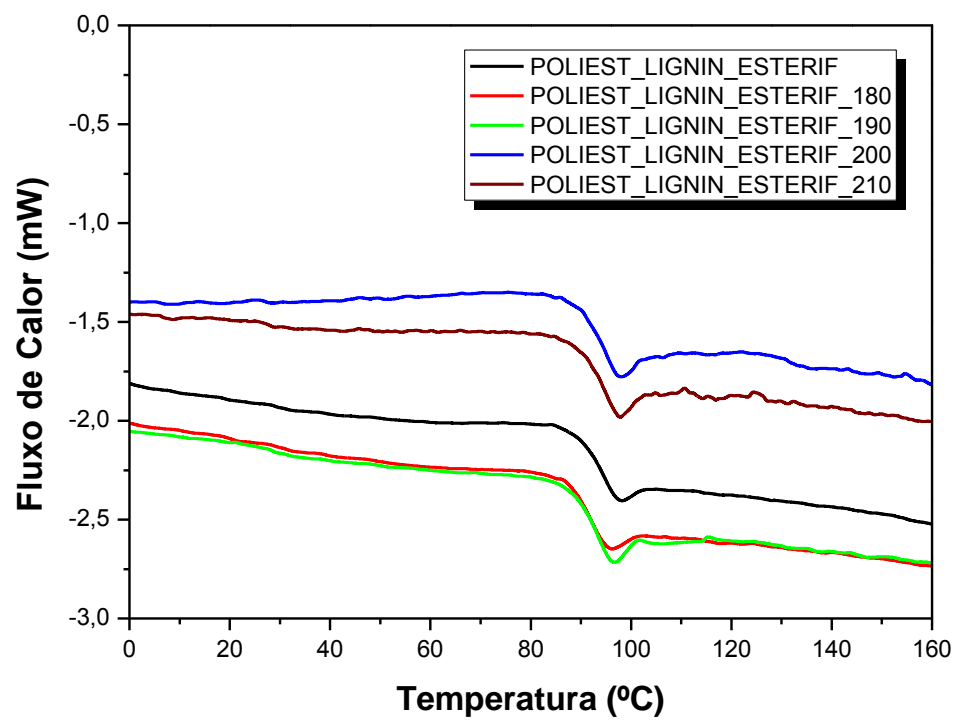

(c)

Figura 47: Curvas de DSC das análises preliminares dos polímeros, onde: (a) poliestireno, (b) poliestireno/lignina $5 \%$ e (c) poliestireno/lignina esterificada $5 \%$. 
Após as análises preliminares, outro estudo foi realizado com as amostras 4 , 7 e 8 do polímero formado com lignina pura e as amostras 4,5 e 7 do polímero formado com lignina esterificada e as amostras de poliestireno, descritas anteriormente. Os ensaios foram realizados em 4 temperaturas $\left(210^{\circ} \mathrm{C}, 230^{\circ} \mathrm{C}\right.$, $250 \stackrel{\circ}{\circ}$ e $290 \stackrel{\circ}{\circ}$ ), com uma velocidade de $0,1 \mathrm{rpm}$ e uma taxa de cisalhamento de $0,03 \mathrm{~s}^{-1}$. Os perfis de viscosidade dos polímeros estão nas Figuras 48 a 50; os dados de estabilidade térmica estão na Figura 51 a 53; as curvas de DSC estão na Figura 54, 55 e 56; e os dados da caracterização térmica estão nas Tabelas 14 a 16.

Os dados mostram que o aumento da concentração de lignina, aumenta consideravelmente a viscosidade dos polímeros. Os polímeros também apresentaram uma boa estabilidade térmica nessas temperaturas. Os valores de transição vítrea $(\mathrm{Tg})$ tiveram um aumento, quando comparados ao poliestireno puro, tendo uma diminuição apenas nos polímeros após ensaios de $290{ }^{\circ} \mathrm{C}$, o que mostrou a degradação dos polímeros nessa temperatura. Podemos afirmar então que a incorporação de lignina na matriz polimérica de estireno melhora as propriedades térmicas do polímero, mesmo em altas temperaturas.

O aumento da viscosidade e da $\mathrm{Tg}$ pode ser explicado pelo aumento do peso molecular da matriz polimérica após adição de lignina e consequente diminuição da mobilidade das cadeias poliméricas do polímero final. ${ }^{61}$ Outro fato que pode explicar são as ligações cruzadas que podem ocorrer na molécula da lignina ou também às reações que podem ocorrer entre os diferentes grupos presentes na lignina, quando o compósito a base de estireno e lignina é submetido a temperaturas elevadas nos ensaios de viscosidade.

Podemos afirmar que os compósitos poliméricos obtidos pela combinação de lignina e estireno têm suas propriedades melhoradas, possuem boa morfologia e podemos inferir dessa pesquisa que, ao menos, após o primeiro tratamento térmico com temperaturas entre $180^{\circ} \mathrm{C}$ e $250{ }^{\circ} \mathrm{C}$, esse compósito terá suas propriedades térmicas melhoradas. 


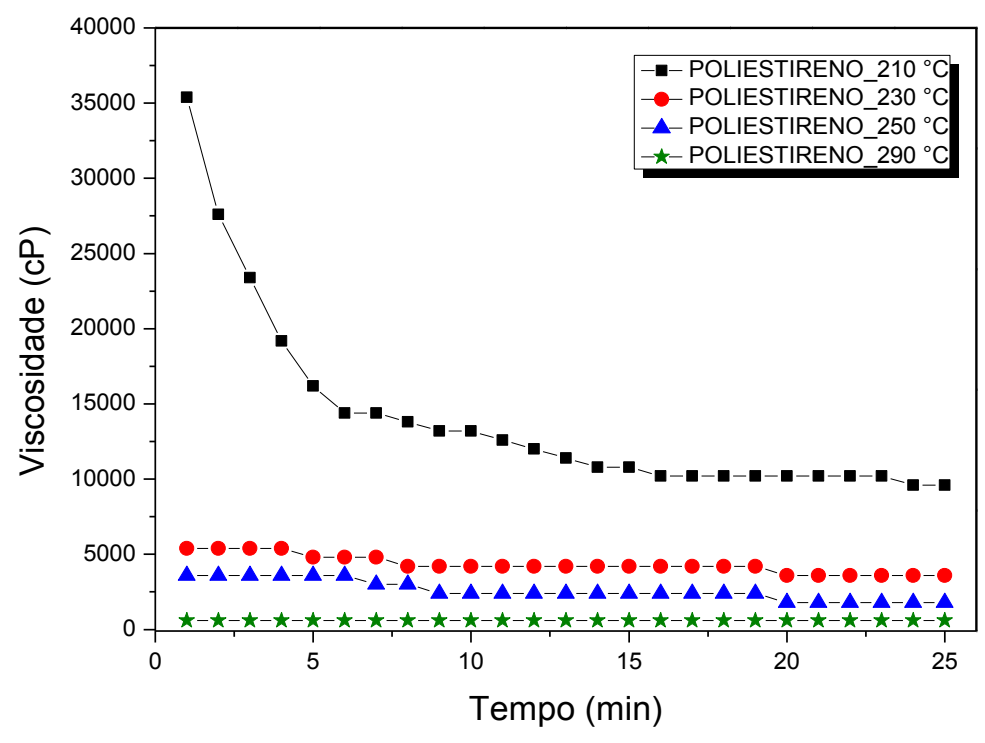

(a)

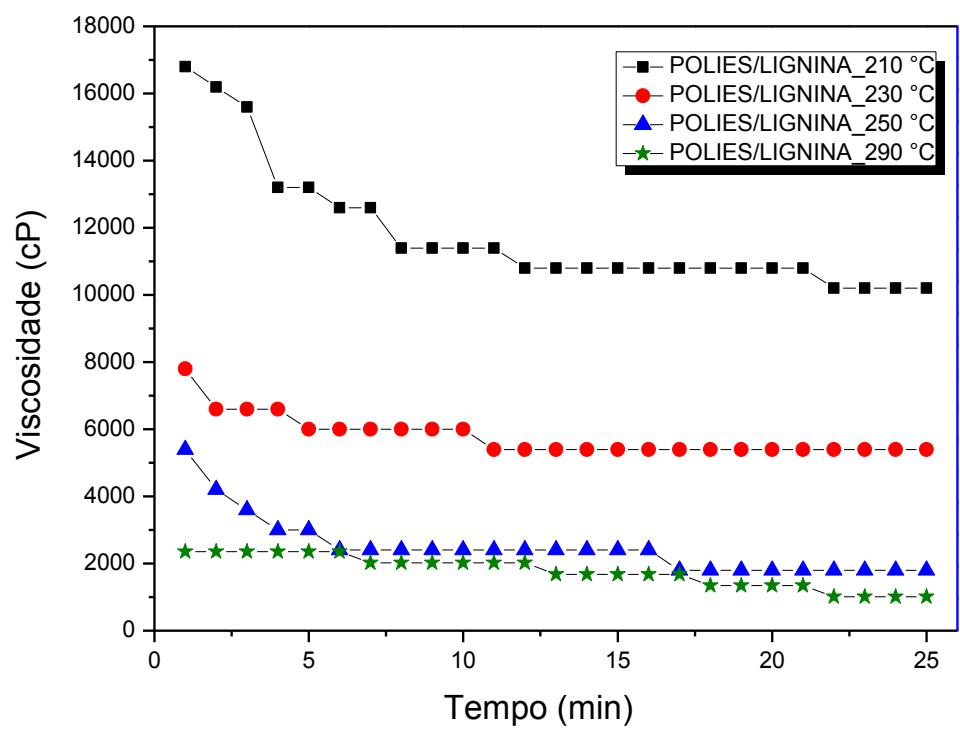

(b)

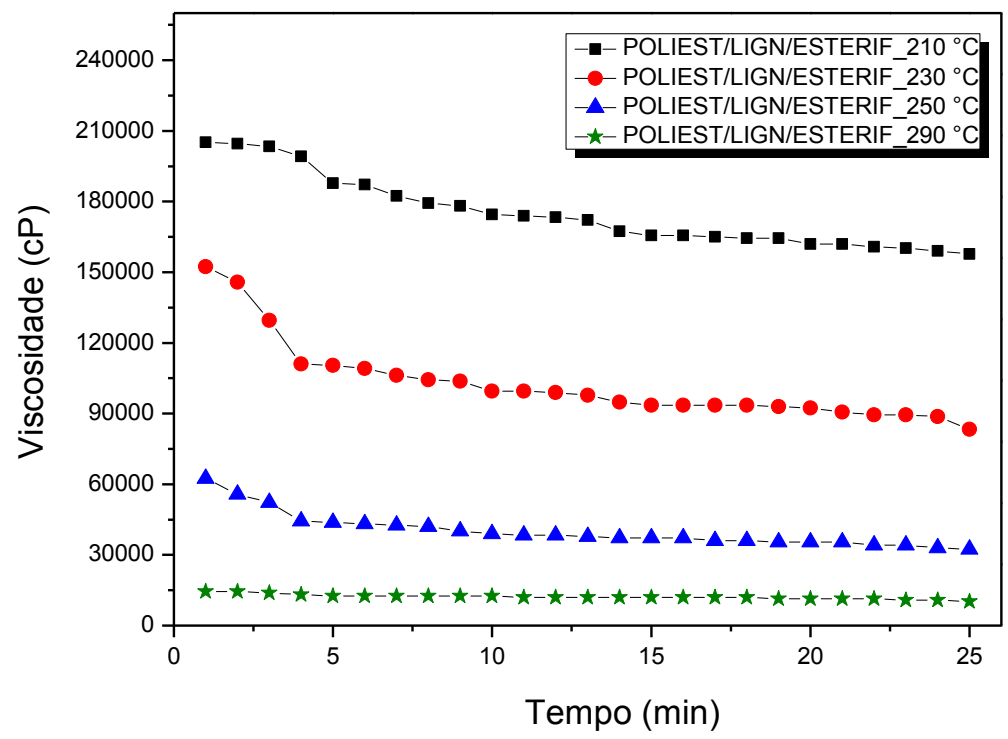

(c)

Figura 48: Perfis de viscosidade, onde: (a) poliestireno, (b) poliestireno/lignina $5 \%$ e (c) poliestireno/lignina esterificada $5 \%$. 


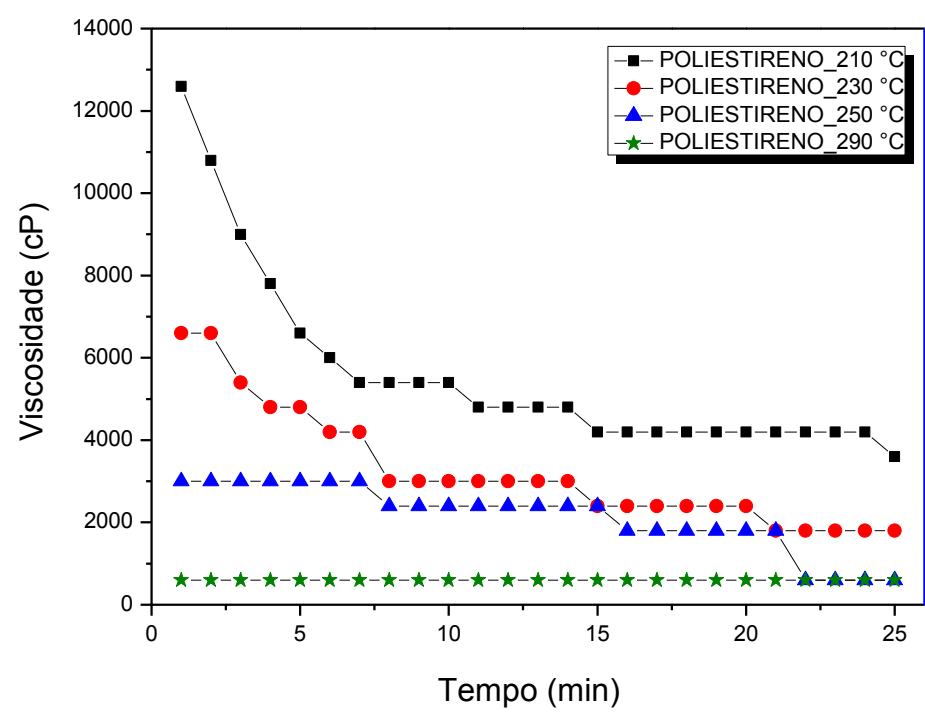

(a)

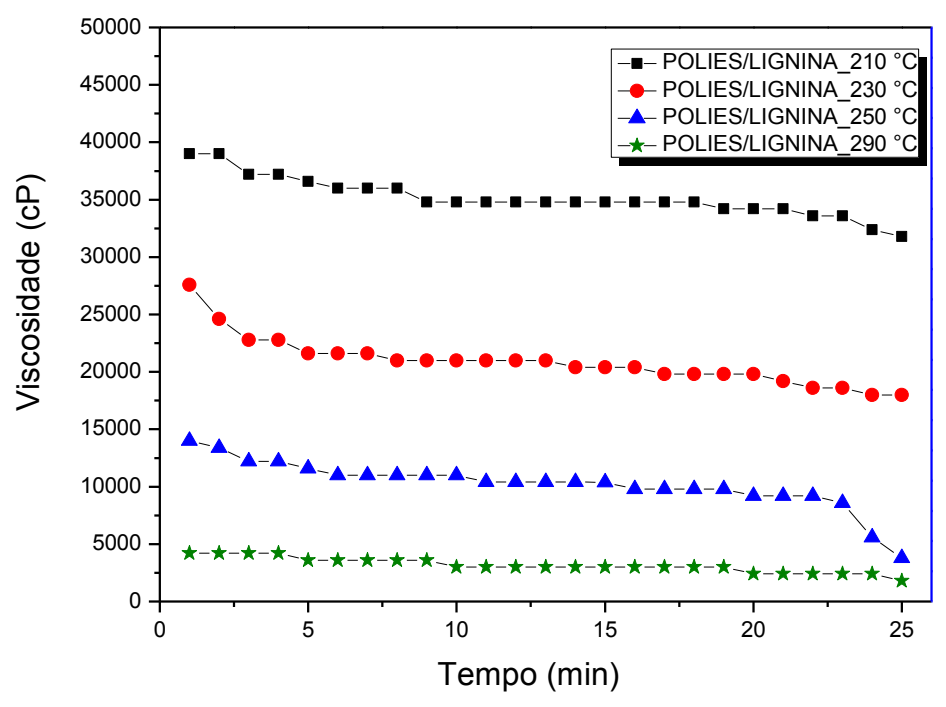

(b)

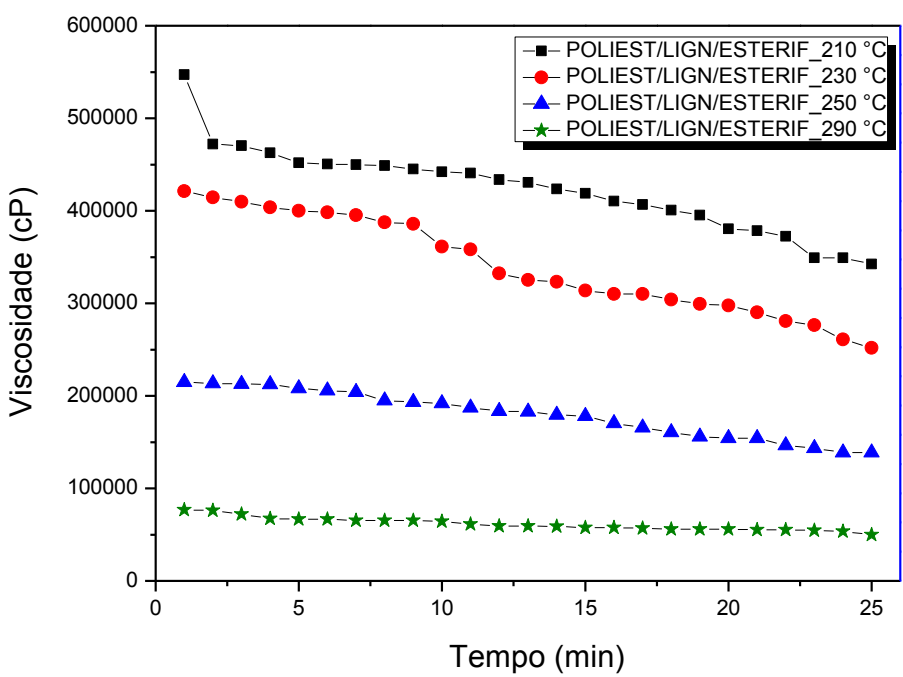

(c)

Figura 49: Perfis de viscosidade, onde: (a) poliestireno, (b) poliestireno/lignina $10 \%$ e (c) poliestireno/lignina esterificada $10 \%$. 


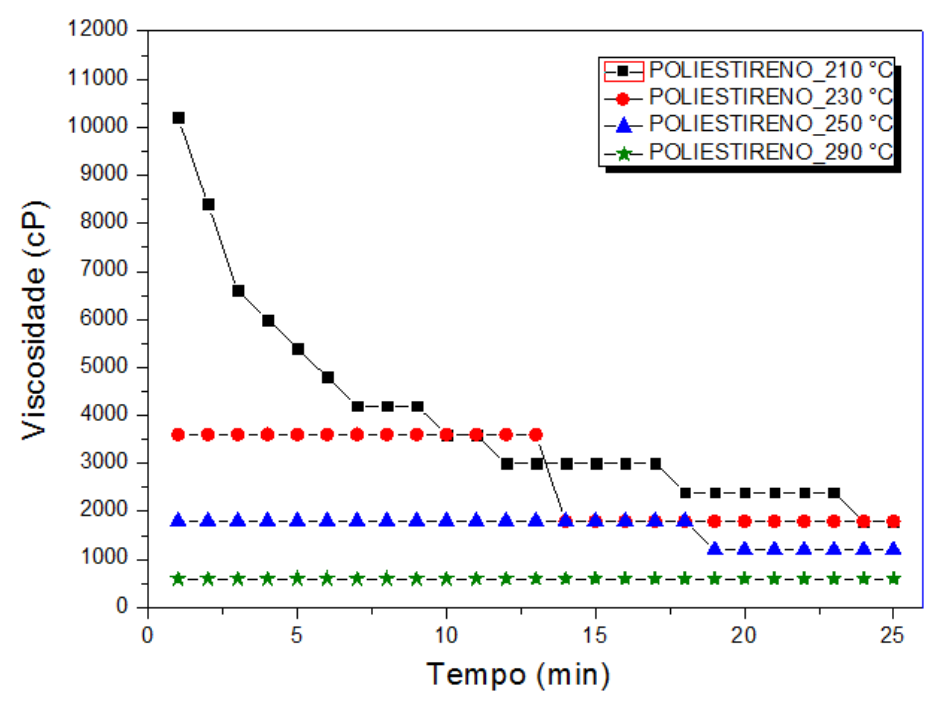

(a)

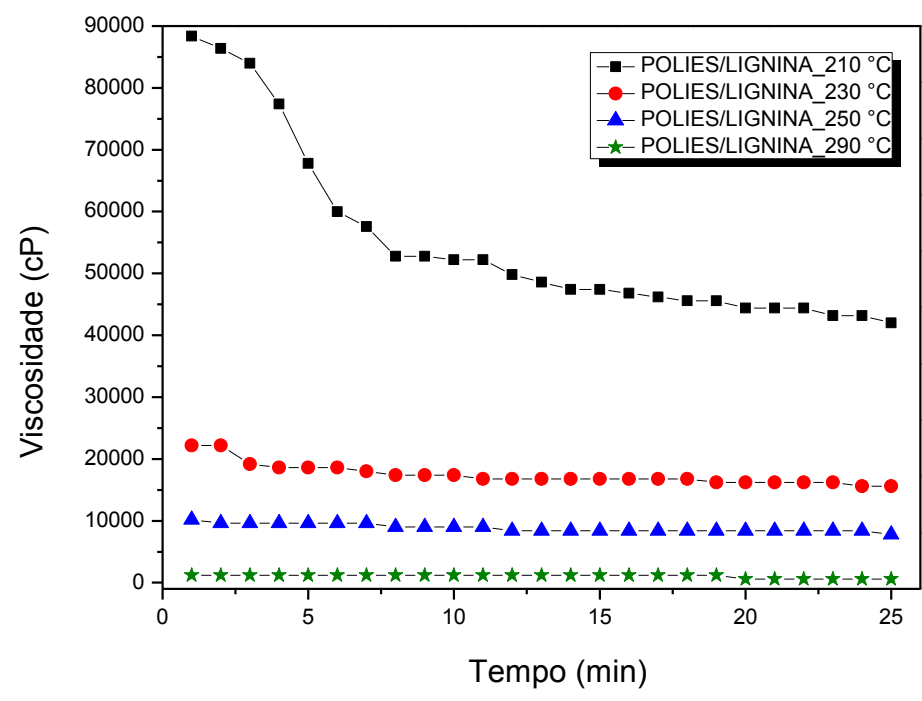

(b)

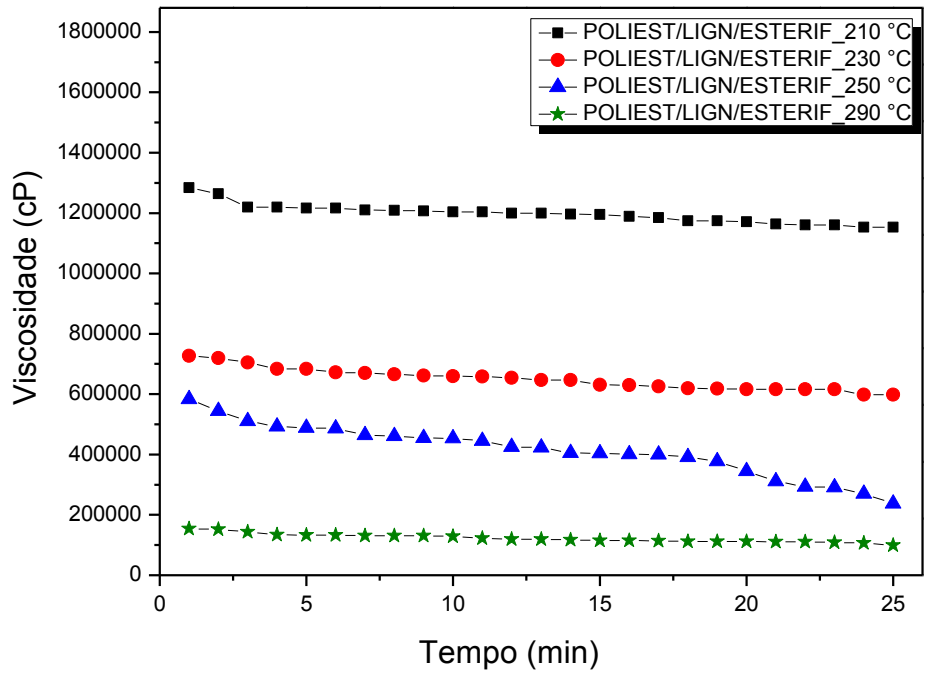

(c)

Figura 50: Perfis de viscosidade, onde: (a) poliestireno, (b) poliestireno/lignina $20 \%$ e (c) poliestireno/lignina esterificada $20 \%$. 

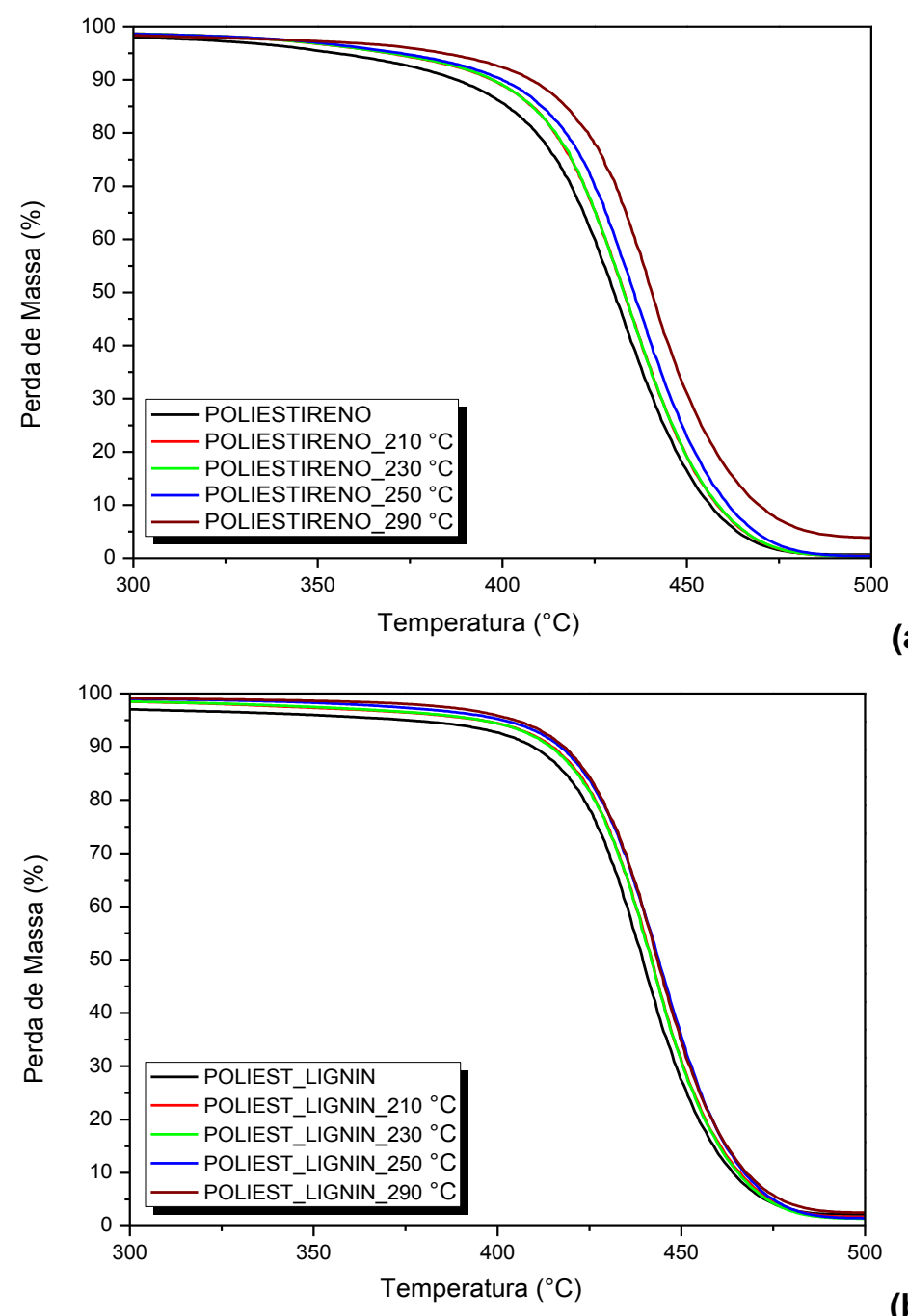

(a)

(b)

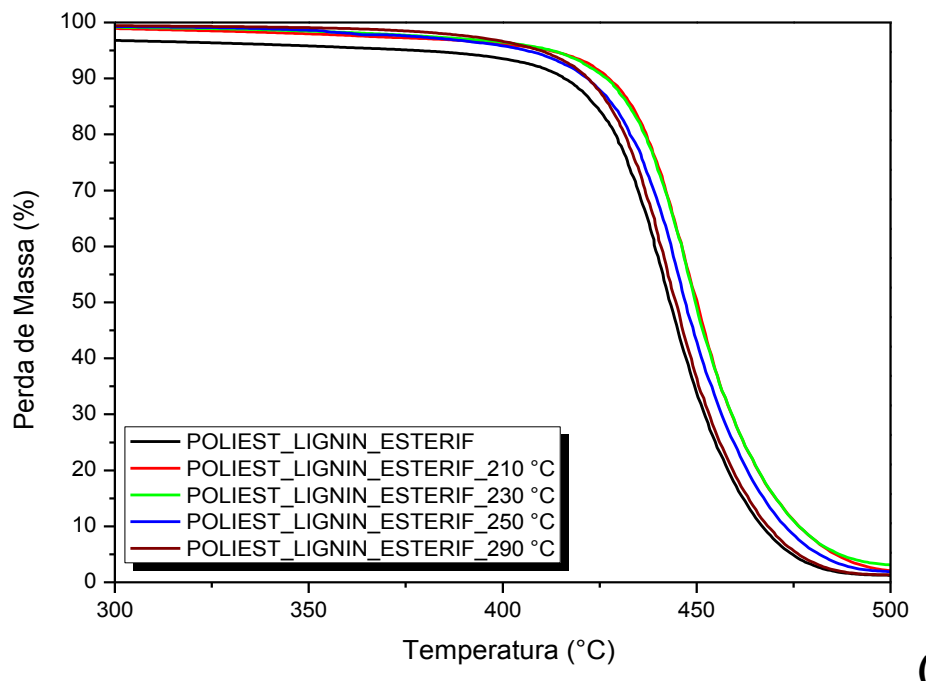

(c)

Figura 51: Estabilidade térmica dos polímeros, onde: (a) poliestireno, (b) poliestireno/lignina $5 \%$ e (c) poliestireno/lignina esterificada $5 \%$. 


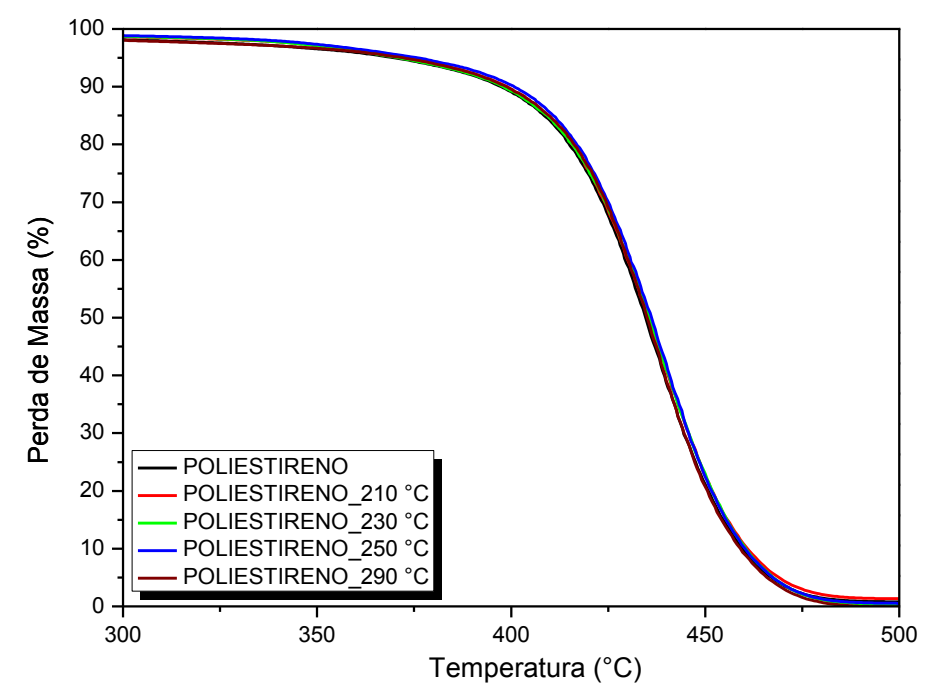

(a)

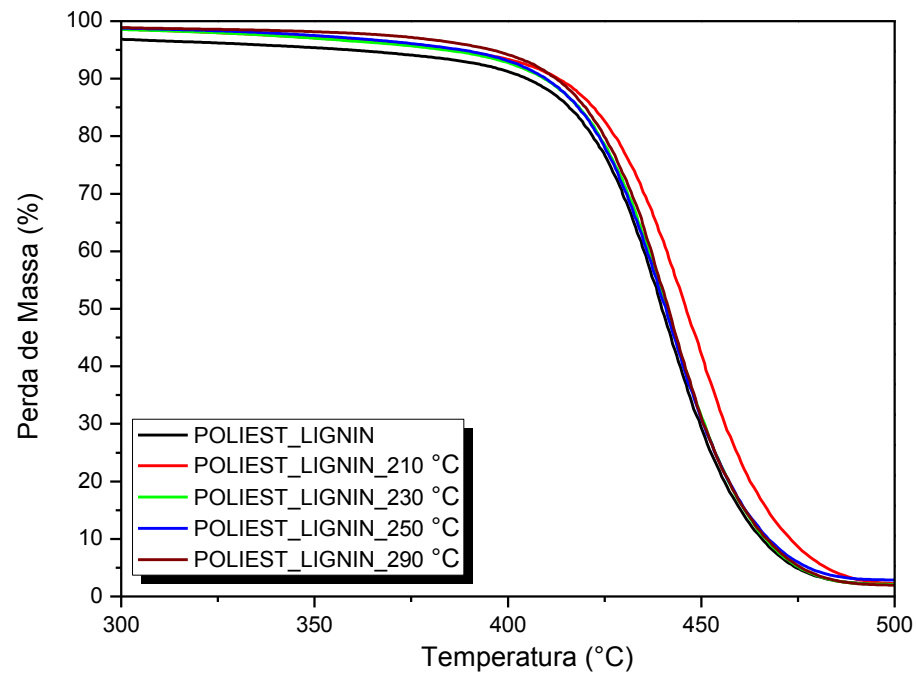

(b)

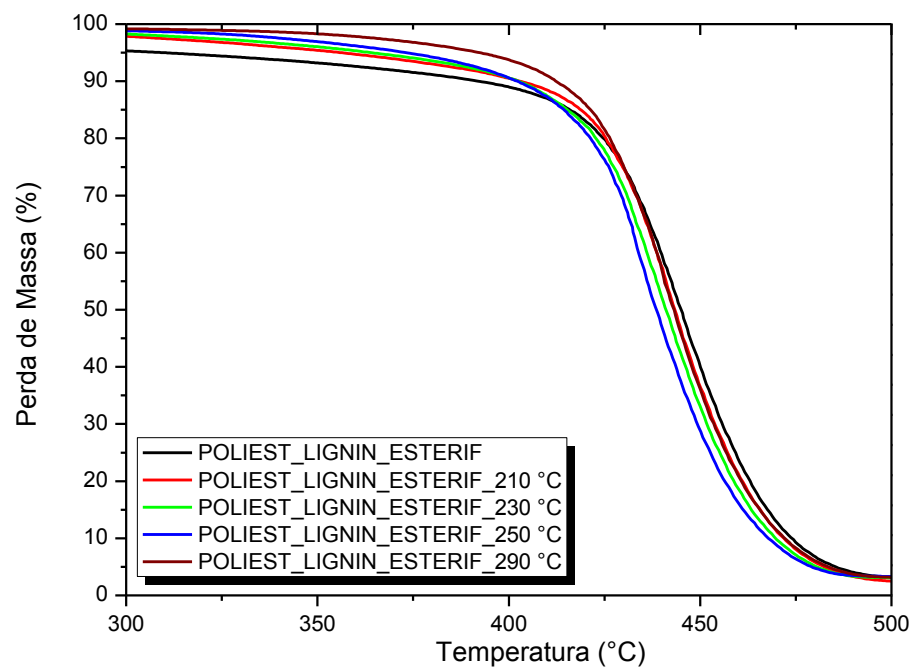

(c)

Figura 52: Estabilidade térmica dos polímeros, onde: (a) poliestireno, (b) poliestireno/lignina $10 \%$ e (c) poliestireno/lignina esterificada $10 \%$. 


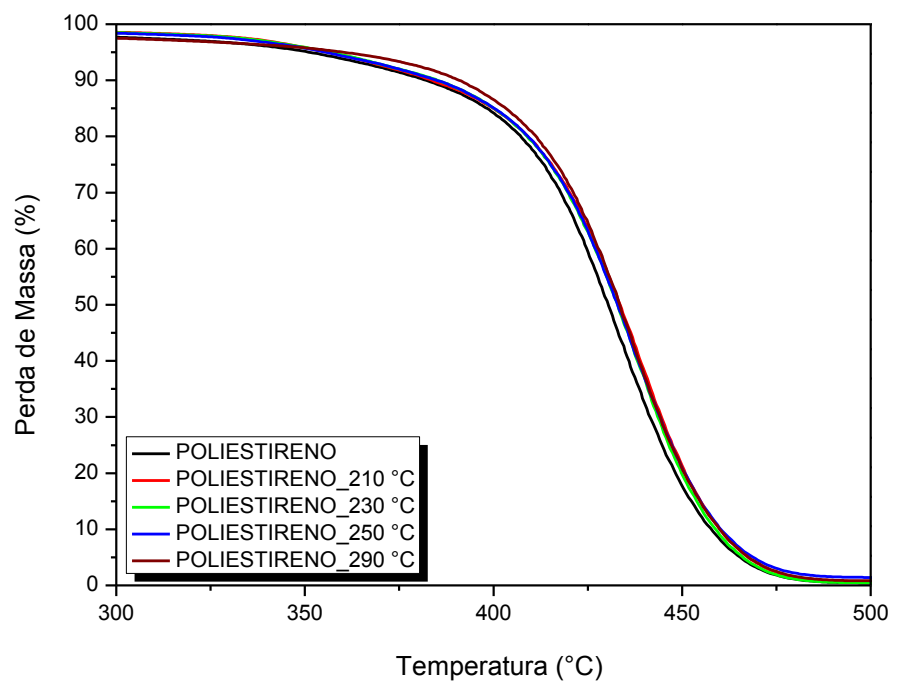

(a)

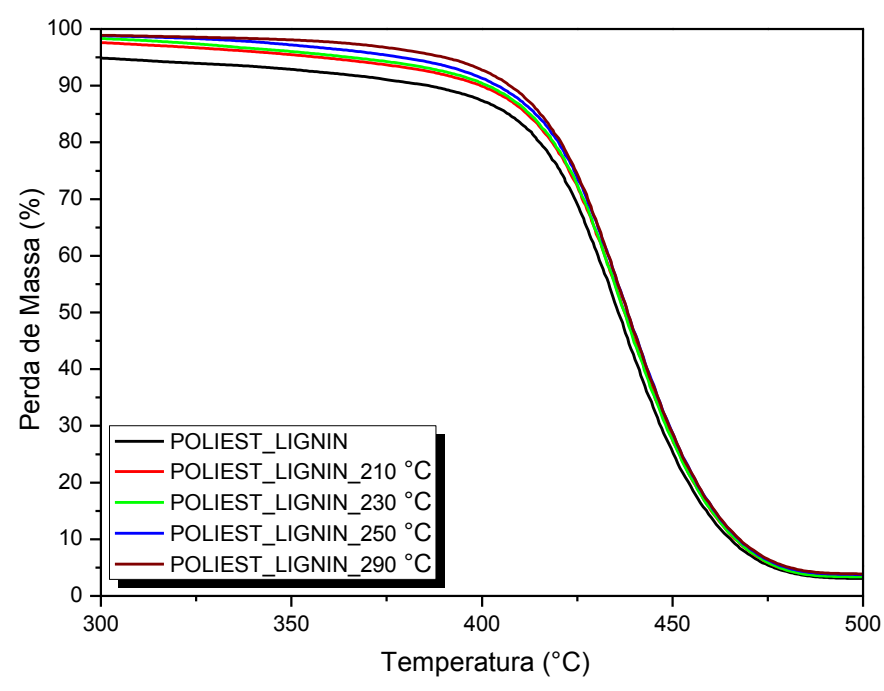

(b)

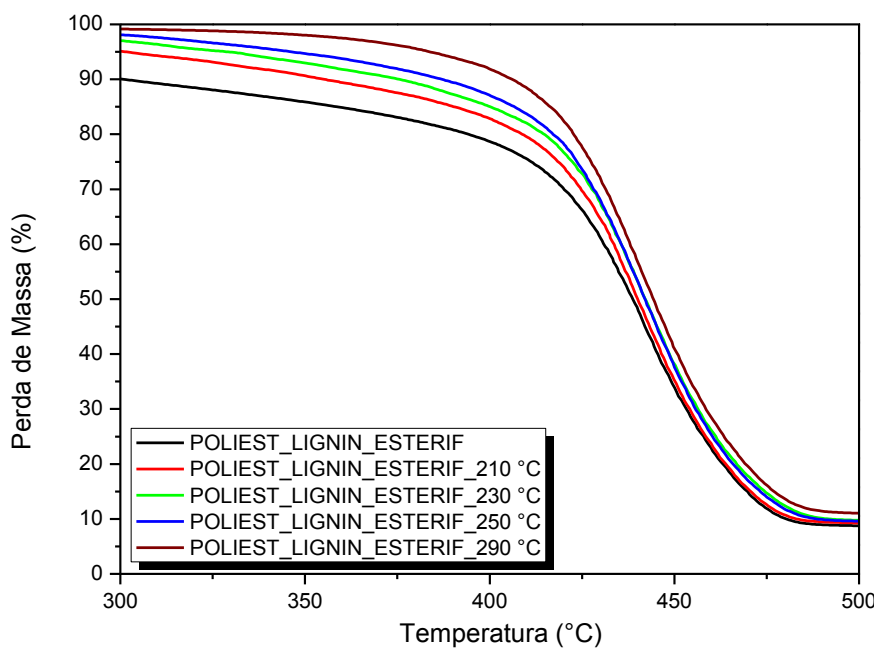

(c)

Figura 53: Estabilidade térmica dos polímeros, onde: (a) poliestireno, (b) poliestireno/lignina $20 \%$ e (c) poliestireno/lignina esterificada $20 \%$. 


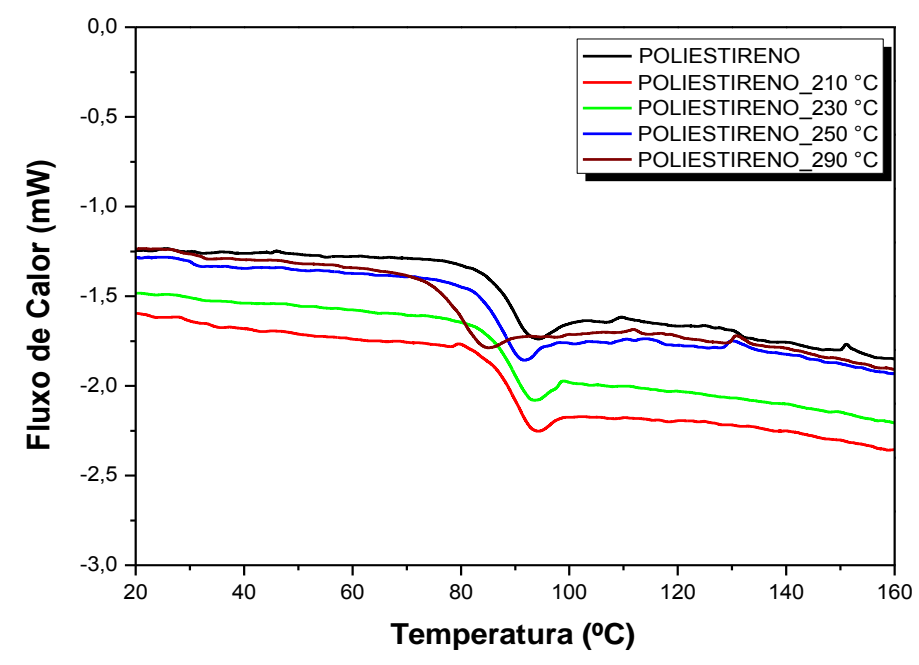

(a)

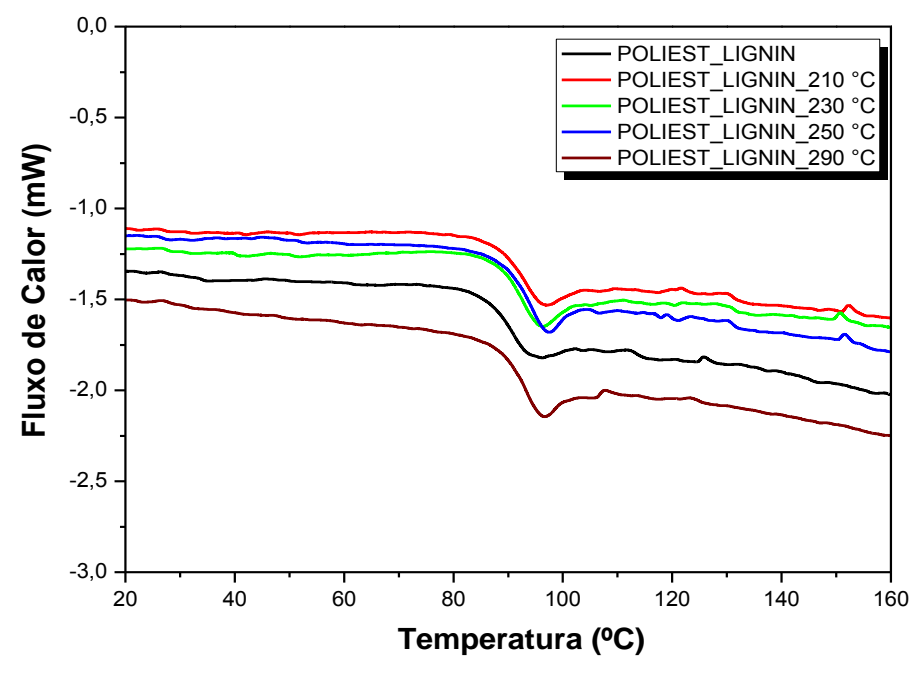

(b)

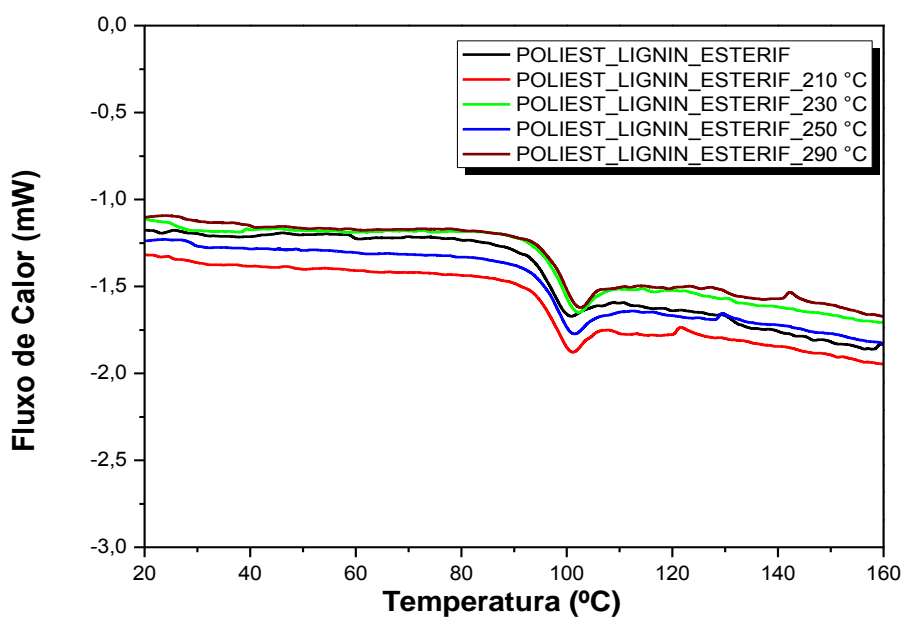

(c)

Figura 54: Curvas de DSC dos polímeros, onde: (a) poliestireno, (b) poliestireno/lignina $5 \%$ e (c) poliestireno/lignina esterificada $5 \%$. 


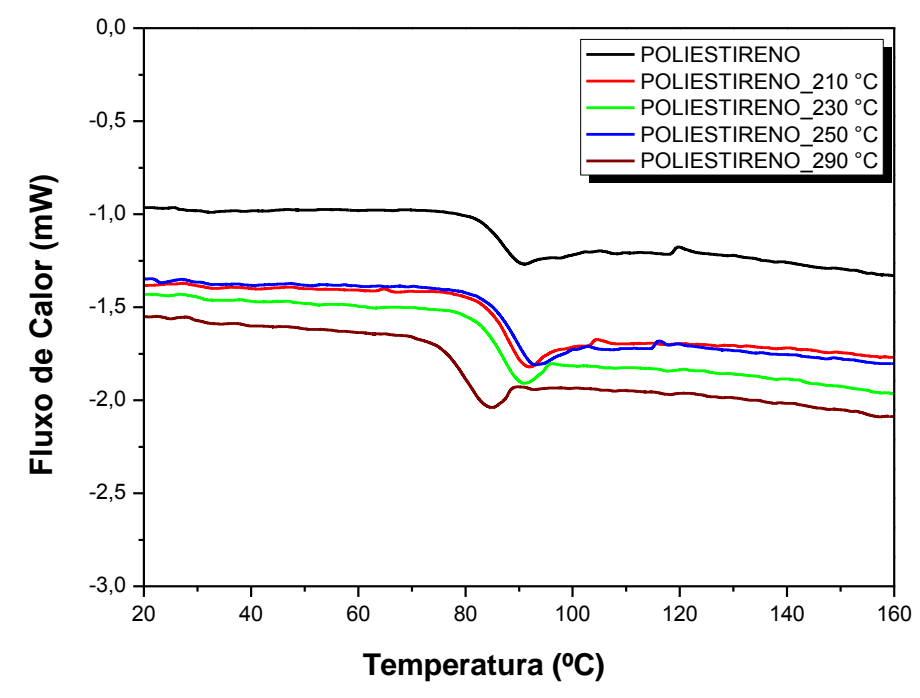

(a)

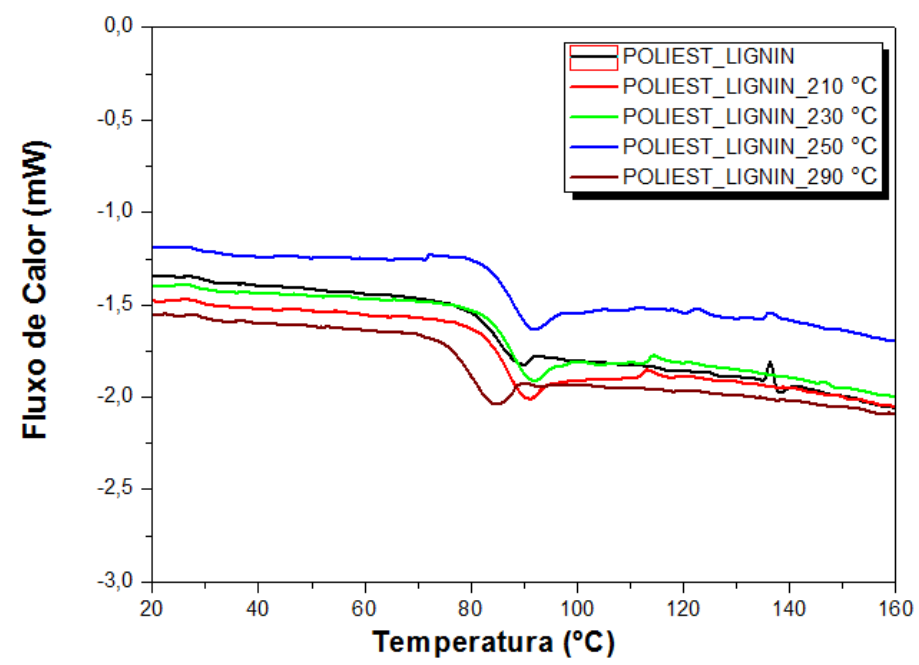

(b)

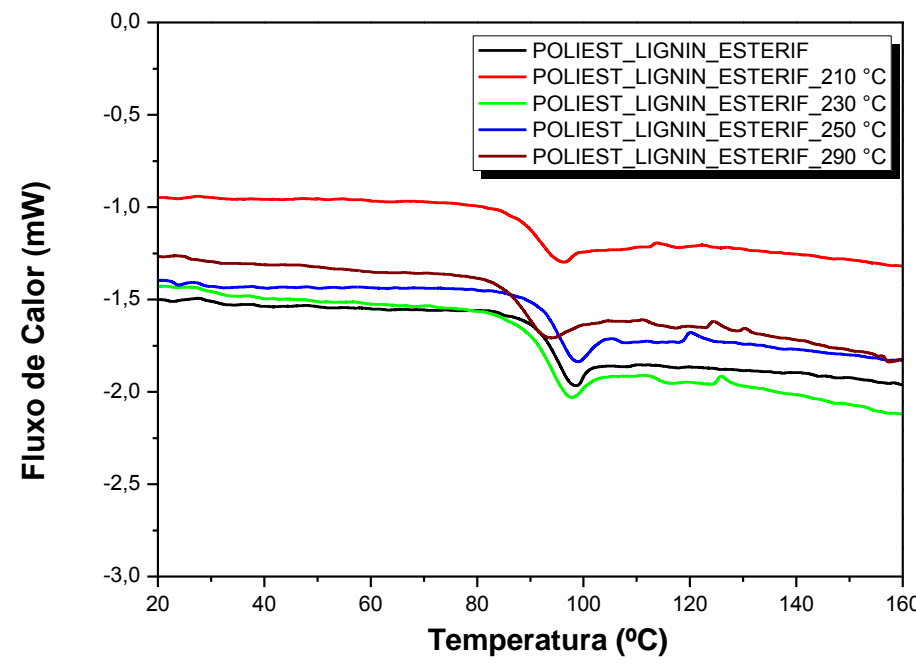

(c)

Figura 55: Curvas de DSC dos polímeros, onde: (a) poliestireno, (b) poliestireno/lignina $10 \%$ e (c) poliestireno/lignina esterificada $10 \%$. 
Tabela 14: Caracterização térmica do poliestireno e dos polímeros formados com poliestireno/lignina $5 \%$ e poliestireno/lignina esterificada $5 \%$.

\begin{tabular}{|c|c|c|c|c|c|}
\hline $\begin{array}{l}\text { Iniciador e } \\
\% \text { de lignina }\end{array}$ & Amostra & $\begin{array}{c}\text { Ensaio de } \\
\text { viscosidade } \\
\left({ }^{\circ} \mathrm{C}\right)\end{array}$ & $\begin{array}{l}\text { Viscosidade } \\
\text { (cP) }\end{array}$ & $\operatorname{Tg}\left({ }^{\circ} \mathrm{C}\right)$ & $\begin{array}{c}\text { Conversão } \\
\text { (\%) }\end{array}$ \\
\hline & \multirow{5}{*}{ 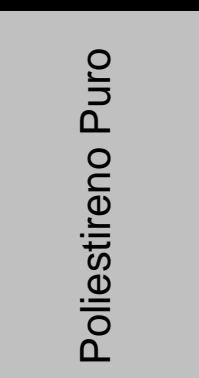 } & -------- & -------- & 90,47 & \multirow{5}{*}{95,8} \\
\hline & & 210 & 9597 & 91,10 & \\
\hline & & 230 & 3599 & 90,98 & \\
\hline & & 250 & 1799 & 88,85 & \\
\hline & & 290 & 599 & 81,34 & \\
\hline \multirow{10}{*}{ 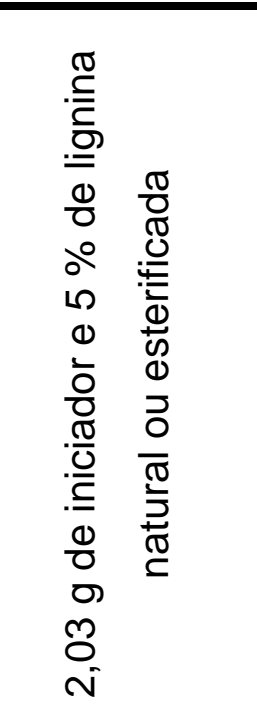 } & \multirow{5}{*}{ 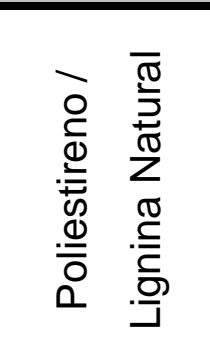 } & -------- & -------- & 91,32 & \multirow{5}{*}{97,3} \\
\hline & & 210 & 10197 & 91,96 & \\
\hline & & 230 & 5398 & 92,18 & \\
\hline & & 250 & 1799 & 93,87 & \\
\hline & & 290 & 1007 & 93,21 & \\
\hline & \multirow{5}{*}{ 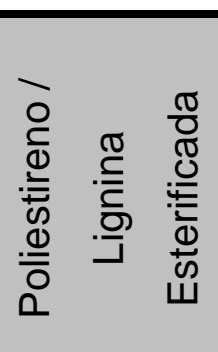 } & -------- & $\begin{array}{l}------- \\
\end{array}$ & 96,67 & \multirow{5}{*}{98,8} \\
\hline & & 210 & 157766 & 96,99 & \\
\hline & & 230 & 83382 & 98,49 & \\
\hline & & 250 & 32393 & 98,50 & \\
\hline & & 290 & 10197 & 98,47 & \\
\hline
\end{tabular}


Tabela 15: Caracterização térmica do poliestireno e dos polímeros formados com poliestireno/lignina $10 \%$ e poliestireno/lignina esterificada $10 \%$.

\begin{tabular}{|c|c|c|c|c|c|}
\hline $\begin{array}{l}\text { Iniciador e } \\
\% \text { de lignina }\end{array}$ & Amostra & $\begin{array}{c}\text { Ensaio de } \\
\text { viscosidade } \\
\text { (ํ) }\end{array}$ & $\begin{array}{l}\text { Viscosidade } \\
\text { (cP) }\end{array}$ & $\operatorname{Tg}\left({ }^{\circ} \mathrm{C}\right)$ & $\begin{array}{c}\text { Conversão } \\
\text { (\%) }\end{array}$ \\
\hline & \multirow{5}{*}{ 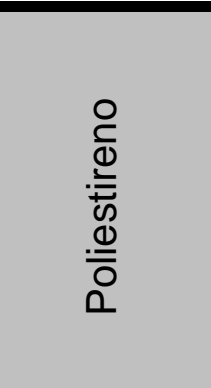 } & -------- & -------- & 87,83 & \multirow{5}{*}{96,7} \\
\hline & & 210 & 3599 & 86,72 & \\
\hline & & 230 & 1799 & 86,18 & \\
\hline & & 250 & 599 & 90,61 & \\
\hline & & 290 & 599 & 78,61 & \\
\hline \multirow{10}{*}{ 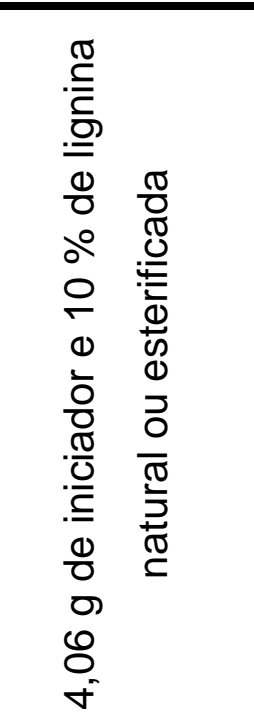 } & \multirow{5}{*}{ 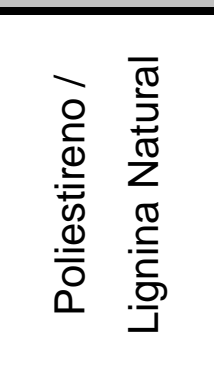 } & -------- & -------- & 86,11 & \multirow{5}{*}{97,8} \\
\hline & & 210 & 31793 & 86,43 & \\
\hline & & 230 & 17996 & 87,99 & \\
\hline & & 250 & 3797 & 88,85 & \\
\hline & & 290 & 1799 & 87,77 & \\
\hline & \multirow{5}{*}{ 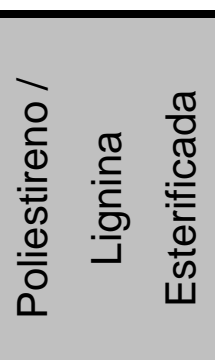 } & -------- & ------- & 90,35 & \multirow{5}{*}{98,7} \\
\hline & & 210 & 342526 & 91,43 & \\
\hline & & 230 & 251946 & 94,51 & \\
\hline & & 250 & 138570 & 95,47 & \\
\hline & & 290 & 49789 & 93,71 & \\
\hline
\end{tabular}


Tabela 16: Caracterização térmica do poliestireno e dos polímeros formados com poliestireno/lignina $20 \%$ e poliestireno/lignina esterificada $20 \%$.

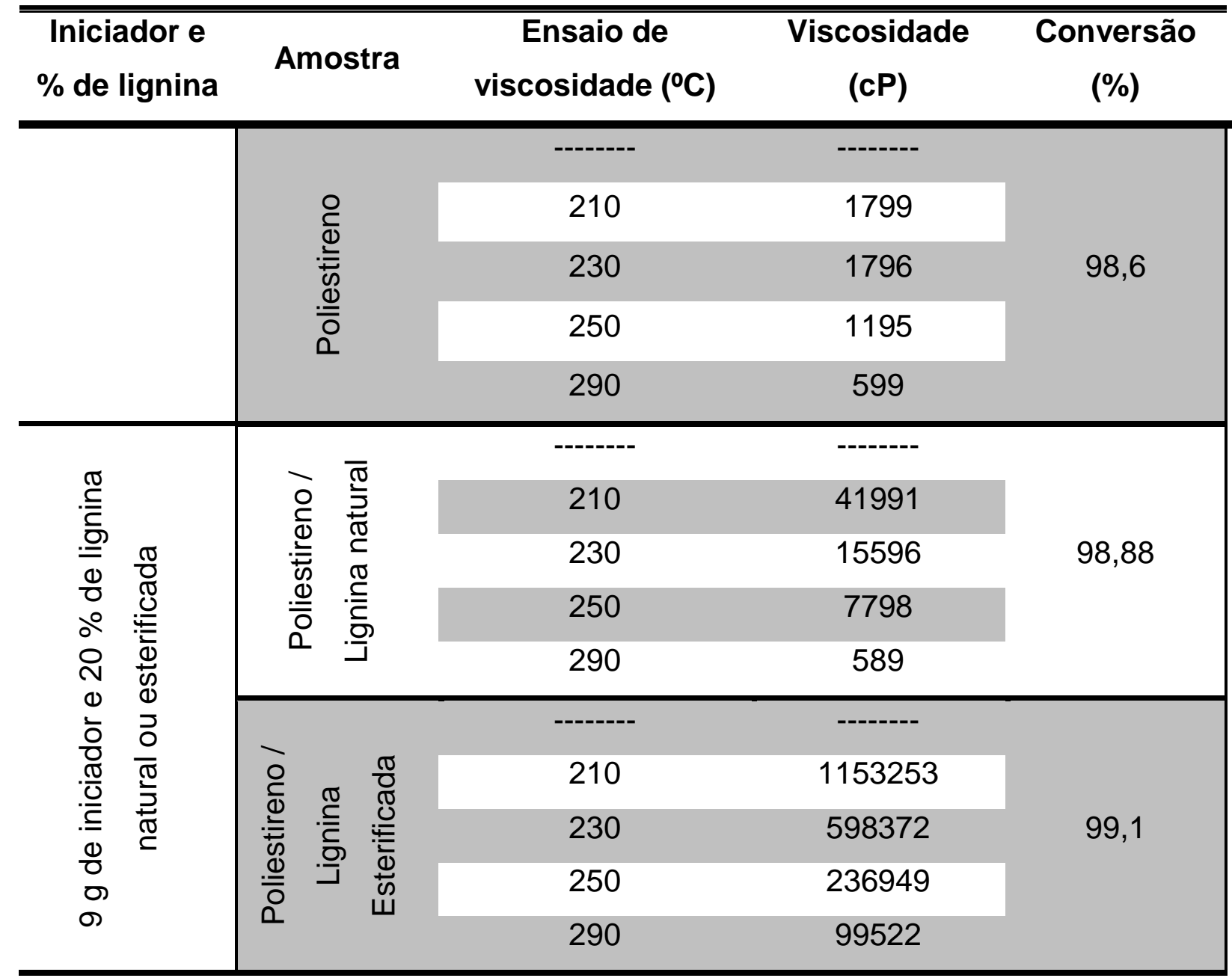


CAPÍTULO 5

CONCLUSÕES 
Neste trabalho foi estudada a adição de lignina natural e esterificada na matriz polimérica de estireno, com o objetivo da formação de um novo material compósito. É importante enfatizar que esse trabalho utilizou um material oriundo de biomassa, que geralmente é queimado para geração de energia ou descartado como rejeito, e o incorporou em uma matriz polimérica sintética, ou seja foi possível substituir até $20 \%$ de um material sintético por lignina, que é um material abundante e renovável.

A extração da lignina pelo método Kraft modificado utilizando apenas $\mathrm{NaOH}$ como espécie ativa foi simples e eficaz, fornecendo amostras representativas da macromolécula de lignina, com um rendimento de aproximadamente 50 \%. A posterior esterificação da lignina com anidrido metacrílico teve um rendimento de aproximadamente 64 \%. Tanto a extração como a esterificação da lignina foram comprovadas por infravermelho (IV) e RMN ${ }^{1} \mathrm{H}$, mostrando picos típicos e também mostrou uma boa substituição das hidroxilas presentes na lignina. O comportamento térmico foi analisado por TGA e DSC que mostrou curvas características da lignina natural, e uma melhor estabilidade térmica da lignina esterificada. Os diferentes tamanhos e morfologia foram avaliados por MEV e microscopia ótica.

O processo de polimerização em massa-suspensão mostrou-se adequado, pois proporcionou uma melhor homogeneidade da fase orgânica do meio reacional, formado polímeros homogêneos e garantindo a adequada dispersão dos componentes durante a reação.

Os compósitos formados pela combinação de lignina natural e estireno foram obtidos com sucesso. Sua morfologia esférica foi comprovada por MEV e microscopia ótica, ambas também mostraram que a lignina foi incorporada ao polímero e que as partículas formadas possuem macro cavidades.

Já os compósitos formados pela combinação de lignina esterificada e estireno, pela análise de MEV e microscopia ótica, não mostraram morfologia esférica, isso devido à baixa agitação e ineficácia do protetor coloidal usado na segunda fase da polimerização. Contudo as partículas formadas foram estáveis e apresentaram grande porosidade.

Os ensaios de viscosidade mostraram um aumento da viscosidade dos compósitos formados com lignina natural e esterificada, sendo mais significativo com lignina esterificada. Esse aumento mostrou uma melhora nas propriedades dos compósitos que foram comprovadas pela análise térmica por TGA e DSC dos compósitos após os ensaios. A estabilidade térmica dos polímeros foi melhorada 
após os ensaios de viscosidade, diante disso podemos inferir que, ao menos, após o primeiro tratamento térmico com temperaturas entre $180^{\circ} \mathrm{C}$ e $250^{\circ} \mathrm{C}$, os compósitos com lignina natural e esterificada terão suas propriedades térmicas melhoradas. Essa característica é importante para o processo de reciclagem de polímeros, onde dependendo do tipo de reciclagem, esse polímero pode ser reprocessado e os materiais obtidos podem ter propriedades térmicas melhores. Outra característica dos polímeros formados é sua porosidade, pois podem ser usados como biomateriais na medicina proporcionando uma melhor fixação do polímero com tecidos vivos e também como material adsorvente. Em particular, no que se refere a área da analítica, polímeros porosos podem ser utilizados como fase estacionária em cromatografia ou como suporte para catalizadores. 


\section{BIBLIOGRAFIA}

(1) Borsoi, C.; Scienza, L. C.; Zattera, A. J.; Angrizani, C. C.: Obtenção e caracterização de compósitos utilizando poliestireno como matriz e resíduos de fibras de algodão da indústria têxtil como reforço. Polímeros 2011, 21, 271-279.

(2) Soroudi, A.; Jakubowicz, I.: Recycling of bioplastics, their blends and biocomposites: A review. European Polymer Journal 2013, 49, 2839-2858.

(3) Morais, S. A. L. d.; Nascimento, E. A. d.; Melo, D. C. d.: Análise da madeira do Pinus oocarpa parte II : caracterização estrutural da lignina de madeira moída. Revista Árvore 2005, 29, 471-478.

(4) Ragauskas, A. J.; Beckham, G. T.; Biddy, M. J.; Chandra, R.; Chen, F.; Davis, M. F.; Davison, B. H.; Dixon, R. A.; Gilna, P.; Keller, M.; Langan, P.; Naskar, A. K.; Saddler, J. N.; Tschaplinski, T. J.; Tuskan, G. A.; Wyman, C. E.: Lignin Valorization: Improving Lignin Processing in the Biorefinery. Science 2014, 344.

(5) Miles, D. C.: Tecnologia dos Polímeros: São Paulo, 1975.

(6) Spinacé, M. A. d. S.; De Paoli, M. A.: A tecnologia da reciclagem de polímeros. Química Nova 2005, 28, 65-72.

(7) Isaia, G. C.: Materiais de Construção Civil e Princípios de Ciência e Engenharia de Materiais; 2aㅡ Edição Atualizada e Ampliada ed.; IBRACON: São Paulo, 2010; Vol. 2.

(8) Hottle, T. A.; Bilec, M. M.; Landis, A. E.: Sustainability assessments of biobased polymers. Polymer Degradation and Stability 2013, 98, 1898-1907.

(9) ABIPLAST: Perfil 21013 - Indústria Brasileira de Transformação de Plásticos.

2013.

(10) Hilburg, S. L.; Elder, A. N.; Chung, H.; Ferebee, R. L.; Bockstaller, M. R.; Washburn, N. R.: A universal route towards thermoplastic lignin composites with improved mechanical properties. Polymer 2014, 55, 995-1003.

(11) Roger M. Rowell, B. A. C. e. a.: Results of chemical modification of lignocellulosic fibers for use in composites. 1993; pp 121-127.

(12) Silva, R. V. d.: Compósitos de resina poliuretano derivada de óleo de mamona e fibras vegetais., Universidade de São paulo, 2003.

(13) Lenzi, M. K.; Cunningham, M. F.; Lima, E. L.; Pinto, J. C.: Modeling of semibatch styrene suspension polymerization processes. J. Appl. Polym. Sci. 2005, 96, 1950-1967.

(14) Machado, F.; Lima, E. L.; Pinto, J. C.: Uma revisão sobre os processos de polimerização em suspensão. Polímeros 2007, 17, 166-179.

(15) Polacco, G.; Semino, D.; Palla, M.: Temperature profiles in batch methyl methacrylate polymerization in gelled suspension. Polymer Engineering \& Science 1996, 36, 2088-2100.

(16) Junior, J. G. F. d. S.: Monitoramento e Controle dos Tamanhos de Partículas em Polimerização em Suspensão do MMA usando NIRS. Universidade Federal do Rio de Janeiro, 2012.

(17) Ockenfels, H.-M.; Uter, W.; Lessmann, H.; Schnuch, A.; Geier, J.: Patch testing with benzoyl peroxide: reaction profile and interpretation of positive patch test reactions. Contact Dermatitis 2009, 61, 209-216.

(18) Campelo, N. M. e. M., F.: Reciclagem de Poli(estireno-divinilbenzeno) via Processo de Polimerização em Massa-Suspensão. In Polímeros.

(19) Torres, M. A. P. R.; Telles, M. T.; Oliveira, C. M. F.: Avaliação das propriedades de misturas de poliestireno com oligômeros de poli(Óxido de Propileno) e poliestireno. Polímeros 1998, 8, 41-45.

(20) Lisperger, J.; Droguett, C.; Ruf, B.; Nunez, M.: The Effect of wood acetylation on thermal behavior of wood-polystyrene composites. Journal of the Chilean Chemical Society 2007, 52, 1073-1075. 
(21) Rodrigues Filho, G.; Assunção, R. M. N.; Marques, F. C. A.; Corrente, N. G.; Meireles, C. S.; Cerqueira, D. A.; Landim, A. S.: Síntese de poliestireno sulfonado para aplicações no tratamento de água produzido a partir de copos e bandejas descartadas de poliestireno. Química Nova 2008, 31, 2004-2008.

(22) Saliba, E. d. O. S.; Rodriguez, N. M.; Morais, S. A. L. d.; Piló-Veloso, D.: Ligninas: métodos de obtenção e caracterização química. Ciência Rural 2001, 31, 917-928.

(23) Chakar, F. S.; Ragauskas, A. J.: Review of current and future softwood kraft lignin process chemistry. Industrial Crops and Products 2004, 20, 131-141.

(24) Henry, N.; Harper, D.; Dadmun, M.: Optimizing Noncovalent Interactions Between Lignin and Synthetic Polymers to Develop Effective Compatibilizers. Macromolecular Chemistry and Physics 2012, 213, 1196-1205.

(25) Thielemans, W.; Can, E.; Morye, S. S.; Wool, R. P.: Novel applications of lignin in composite materials. J. Appl. Polym. Sci. 2002, 83, 323-331.

(26) Doherty, W. O. S.; Mousavioun, P.; Fellows, C. M.: Value-adding to cellulosic ethanol: Lignin polymers. Industrial Crops and Products 2011, 33, 259-276.

(27) Thielemans, W.; Wool, R. P.: Lignin Esters for Use in Unsaturated Thermosets: Lignin Modification and Solubility Modeling. Biomacromolecules 2005, 6, 18951905.

(28) Fernandes, E. M.; Pires, R. A.; Mano, J. F.; Reis, R. L.: Bionanocomposites from lignocellulosic resources: Properties, applications and future trends for their use in the biomedical field. Progress in Polymer Science 2013, 38, 1415-1441.

(29) Košíková, B.; Gregorová, A.: Sulfur-free lignin as reinforcing component of styrene-butadiene rubber. J. Appl. Polym. Sci. 2005, 97, 924-929.

(30) Piló-Veloso, D.: Isolamento e Análise Estrutural de Ligninas. In Química Nova: Brasil, 1993; Vol. 16; pp 435-448.

(31) Ayoub, A.; Venditti, R. A.; Jameel, H.; Chang, H.-M.: Effect of irradiation on the composition and thermal properties of softwood kraft lignin and styrene grafted lignin. $J$. Appl. Polym. Sci. 2014, 131, n/a-n/a.

(32) Sun, X.-F.; Wang, H.; Zhang, G.; Fowler, P.; Rajaratnam, M.: Extraction and characterization of lignins from maize stem and sugarcane bagasse. J. Appl. Polym. Sci. 2011, 120, 3587-3595.

(33) Lewis, N. G.; Yamamoto, E.: Lignin: Occurrence, Biogenesis and Biodegradation. Annual Review of Plant Physiology and Plant Molecular Biology 1990, 41, 455-496.

(34) Barton li, F. E.: Chemistry of lignocellulose: Methods of analysis and consequences of structure. Animal Feed Science and Technology 1988, 21, 279-286.

(35) Richard P. Wool , X. S. S.: Lignin polymers and composites. In Bio-Based Polymers and Composites; Books, E. S. T., Ed., 2005; pp 551-598.

(36) Gonzalez Sanchez, C.: Materiales Compuestos Termoplastico/Lignina y su Procedimiento de Obtencion. Intelectual, O. M. d. I. P., Ed.; Ibañes, Jose F: Espanha, 1998; Vol. C08I 101/00; pp 29.

(37) Zanuncio, A. J. V.; Colodette, J. L.: Teores de lignina e ácidos urônicos na madeira e polpa celulósica de Eucalipto. Revista Árvore 2011, 35, 341-347.

(38) Cachet, N.; Camy, S.; Benjelloun-Mlayah, B.; Condoret, J.-S.; Delmas, M.: Esterification of organosolv lignin under supercritical conditions. Industrial Crops and Products 2014, 58, 287-297.

(39) Botaro, V. R.; dos Santos, C. G.; Arantes Júnior, G.; da Costa, A. R.: Chemical modification of lignocellulosic materials by irradiation with Nd-YAG pulsed laser. Applied Surface Science 2001, 183, 120-125.

(40) Kaewtatip, K.; Thongmee, J.: Effect of kraft lignin and esterified lignin on the properties of thermoplastic starch. Materials \& Design 2013, 49, 701-704.

(41) Fukushima, R. S.; Garippo, G.; Habitante, A. M. Q. B.; Lacerda, R. S.: Extração da lignina e emprego da mesma em curvas de calibração para a mensuração da lignina em produtos vegetais. Revista Brasileira de Zootecnia 2000, 29, 1302-1311. 
(42) Pitarelo, A. P.; Silva, T. A. d.; Peralta-Zamora, P. G.; Ramos, L. P.: Efeito do teor de umidade sobre o pré-tratamento a vapor e a hidrólise enzimática do bagaço de canade-açúcar. Química Nova 2012, 35, 1502-1509.

(43) Chauhan, M.; Gupta, M.; Singh, B.; Singh, A. K.; Gupta, V. K.: Effect of functionalized lignin on the properties of lignin-isocyanate prepolymer blends and composites. European Polymer Journal 2014, 52, 32-43.

(44) Cohen, J. L.; Fong, G. P.: Source of selectivity in the quantitative determination of alcohols by acylation with cyclic anhydrides. Analytical Chemistry 1975, 47, 313-316.

(45) Fox, C.: Chemical and Thermal Characterization of Three Industrial Lignins and Their Corresponding Lignin Esters. University of Idaho, 2006.

(46) Wachowiak, R.; Connors, K. A.: N-Methylimidazole-catalyzed acetylation of hydroxy compounds prior to gas chromatographic separation and determination. Analytical Chemistry 1979, 51, 27-30.

(47) Bittner, A. S.; Harris, L. E.; Campbell, W. F.: Rapid N-methylimidazolecatalyzed acetylation of plant cell wall sugars. Journal of Agricultural and Food Chemistry $1980,28,1242-1245$.

(48) Dee, L. A.; Biggers, B. L.; Fiske, M. E.: N-Methylimidazole as a catalyst for acetylation of hydroxyl terminated polymers. Analytical Chemistry 1980, 52, 572-573.

(49) Rosa, D. d. S.; Silveira, A. d. F.; Madaleno, E.; Tavares, M. I. B.: Estudo do efeito da incorporação de plastificante de fonte renovável em compostos de PVC. Polímeros 2013, 23, 570-581.

(50) Silva, A. M. S.; Viana, E. d. A.; Pimentel, M. F.; Almeida, Y. M. B.; Raimundo Jr, I. M.: Evaluation of a PVC sensing phase for determination of chlorinated hydrocarbons in water by mid-infrared spectroscopy. Journal of the Brazilian Chemical Society 2011, 22, 1470-1477.

(51) Dallmeyer, I.; Lin, L. T.; Li, Y.; Ko, F.; Kadla, J. F.: Preparation and Characterization of Interconnected, Kraft Lignin-Based Carbon Fibrous Materials by Electrospinning. Macromolecular Materials and Engineering 2014, 299, 540-551.

(52) Gouveia, E. R.; Nascimento, R. T. d.; Souto-Maior, A. M.; Rocha, G. J. d. M.: Validação de metodologia para a caracterização química de bagaço de cana-de-açúcar. Química Nova 2009, 32, 1500-1503.

(53) Tejado, A.; Peña, C.; Labidi, J.; Echeverria, J. M.; Mondragon, I.: Physicochemical characterization of lignins from different sources for use in phenol-formaldehyde resin synthesis. Bioresource Technology 2007, 98, 1655-1663.

(54) Wexler, A. S.: Characterization of Lignosulfonates by Ultraviolet Spectrometry. Direct and Difference Spectrograms. Analytical Chemistry 1964, 36, 213-221.

(55) Xie, H.; King, A.; Kilpelainen, I.; Granstrom, M.; Argyropoulos, D. S.: Thorough Chemical Modification of Wood-Based Lignocellulosic Materials in Ionic Liquids. Biomacromolecules 2007, 8, 3740-3748.

(56) Boeriu, C. G.; Fiţigău, F. I.; Gosselink, R. J. A.; Frissen, A. E.; Stoutjesdijk, J.; Peter, F.: Fractionation of five technical lignins by selective extraction in green solvents and characterisation of isolated fractions. Industrial Crops and Products 2014, 62, 481-490.

(57) Yu, Y.; Li, X.; Su, L.; Zhang, Y.; Wang, Y.; Zhang, H.: The role of shape selectivity in catalytic fast pyrolysis of lignin with zeolite catalysts. Applied Catalysis A: General 2012, 447-448, 115-123.

(58) El Mansouri, N.-E.; Salvadó, J.: Analytical methods for determining functional groups in various technical lignins. Industrial Crops and Products 2007, 26, 116-124.

(59) Nazarpour, F.; Abdullah, D. K.; Abdullah, N.; Motedayen, N.; Zamiri, R.: Biological Pretreatment of Rubberwood with Ceriporiopsis subvermispora for Enzymatic Hydrolysis and Bioethanol Production. BioMed Research International 2013, 2013, 268349.

(60) Bittencourt, P. R. S.: Náilon 6 e 6,6 em Blendas com Lignina Kraft Modificada por Ácido Fórmico: Caracterização e Efeito de Radiação UV. Tese, Universidade Estadual de Maringá, 2008. 
(61) Reza Barzegari, M.; Alemdar, A.; Zhang, Y.; Rodrigue, D.: Mechanical and rheological behavior of highly filled polystyrene with lignin. Polymer Composites 2012, 33, 353-361.

(62) Gordobil, O.; Egüés, I.; Llano-Ponte, R.; Labidi, J.: Physicochemical properties of PLA lignin blends. Polymer Degradation and Stability 2014, 108, 330-338.

(63) Monteil-Rivera, F.; Paquet, L.: Solvent-free catalyst-free microwave-assisted acylation of lignin. Industrial Crops and Products.

(64) Sai Ram, M.; Palaniappan, S.: Benzoyl peroxide oxidation route to polyaniline salt and its use as catalyst in the esterification reaction. Journal of Molecular Catalysis A: Chemical 2003, 201, 289-296.

(65) Odian, G.: Principles of Polimerization; John Wiley \& Sons, Inc. ed.; New Jersey: Hoboken, 2004.

(66) Aranha, I. B.; Lucas, E. F.: Poli(Álcool Vinílico) Modificado com Cadeias Hidrocarbônicas: Avaliação do Balanço Hidrófilo/Lipófilo. Polímeros 2001, 11, 174-181. 